\title{
News Media Coverage and Corporate Leverage Adjustments
}

DOI:

http://dx.doi.org/10.2139/ssrn.3109477

10.1016/j.jbankfin.2019.105666

\section{Document Version}

Accepted author manuscript

Link to publication record in Manchester Research Explorer

\section{Citation for published version (APA):}

Dang, T. L., Dang, V. A., Moshirian, F., Nguyen, L., \& Zhang, B. (2019). News Media Coverage and Corporate Leverage Adjustments. Journal of Banking and Finance, 109(105666). https://doi.org/10.2139/ssrn.3109477, https://doi.org/10.1016/j.jbankfin.2019.105666

\section{Published in:}

Journal of Banking and Finance

\section{Citing this paper}

Please note that where the full-text provided on Manchester Research Explorer is the Author Accepted Manuscript or Proof version this may differ from the final Published version. If citing, it is advised that you check and use the publisher's definitive version.

\section{General rights}

Copyright and moral rights for the publications made accessible in the Research Explorer are retained by the authors and/or other copyright owners and it is a condition of accessing publications that users recognise and abide by the legal requirements associated with these rights.

\section{Takedown policy}

If you believe that this document breaches copyright please refer to the University of Manchester's Takedown Procedures [http://man.ac.uk/04Y6Bo] or contact uml.scholarlycommunications@manchester.ac.uk providing relevant details, so we can investigate your claim.

\section{OPEN ACCESS}




\title{
News Media Coverage and Corporate Leverage Adjustments
}

\author{
Tung Lam Dang, Viet Anh Dang, Fariborz Moshirian, Lily Nguyen, and Bohui Zhang ${ }^{1}$ \\ Forthcoming in Journal of Banking and Finance
}

This version: September 2019

\begin{abstract}
We examine the impact of the media on firms' leverage adjustments. Using a comprehensive sample of global news across 33 countries, we find that greater news coverage and more positive news sentiment are associated with greater leverage adjustment speeds. This finding is consistent with the argument that media coverage and content help lower the cost of firms' adjustment toward target leverage. We further find evidence supporting two mechanisms through which the news media affects leverage adjustments: information dissemination and monitoring. Overall, our results are consistent with the dynamic trade-off theory of capital structure.

JEL Classification: G30; G32; G12; G15

Keywords: Media Coverage; Capital Structure; Speed of Leverage Adjustment; Trade-off Theory

1 Tung Lam Dang is from the University of Economics, University of Danang, Vietnam. Viet Anh Dang (Corresponding author) is from Alliance Manchester Business School, University of Manchester, United Kingdom. Fariborz Moshirian is from UNSW Business School, University of New South Wales, Australia. Lily H.G. Nguyen is from UQ Business School, University of Queensland, Australia. Bohui Zhang is from Chinese University of Hong Kong, China. We would like to thank the editor (Carol Alexander), two anonymous referees, Paul Brockman, Murillo Campello, Tolga Cenesizoglu, Ran Duchin, Marie Dutordoir, Susanne Espenlaub, Robert Faff, Vidhan Goyal, Sigitas Karpavicius, Olga Kolokolova, Alex Kostakis, Maria Marchica, Yoichi Otsubo, Gordon Phillips, Ser-Huang Poon, Konstantinos Stathopoulos, Avanidhar (Subra) Subrahmanyam, and participants and discussants at the $29^{\text {th }}$ Australasian Finance and Banking Conference 2016, the Vietnam International Conference in Finance (VICIF) 2017, the Financial Integrity Research Network (FIRN) Research Topic Group Meeting in Corporate Finance 2017, the Financial Management Association Annual Meetings 2017, as well as seminar participants at Alliance Manchester Business School, Australian National University, and La Trobe University for helpful comments and suggestions on previous versions of the paper. We would like to acknowledge financial support from the Australian Research Council (ARC) Linkage Grant, and the research grant (Grant number 502.02-2015.07) from Vietnam National Foundation for Science and Technology Development (NAFOSTED) for this project. All remaining errors are our own.

Authors' contact information: Tung Lam Dang: dangtlam@due.edu.vn; Viet Anh Dang (Corresponding author): vietanh.dang@manchester.ac.uk, +44 (0) 161275 0438, Alliance Manchester Business School, University of Manchester, M15 6PB, Manchester, United Kingdom; Fariborz Moshirian: f.moshirian@unsw.edu.au; Lily Nguyen: lily.nguyen@business.uq.edu.au; Bohui Zhang: bohuizhang@cuhk.edu.cn.
\end{abstract}




\section{Introduction}

The traditional trade-off view of capital structure argues that a firm can maximize its value by operating at an optimal level of leverage, which balances the benefits (e.g., debt tax shields) against the costs (e.g., financial distress costs) of debt financing. Subsequent dynamic trade-off models predict that firms have an incentive to move toward their target leverage ratios by reducing any deviations from those targets (see Frank and Goyal (2008) for a review). However, while adjusting to the optimal mix of debt and equity, a firm may encounter substantial financing frictions and hence significant leverage adjustment costs (e.g., Fischer, Heinkel, and Zechner, 1989); these, in turn, can reduce the speed of adjustment (hereafter, SOA). ${ }^{1}$

Meanwhile, a separate but growing body of literature has highlighted the important role of the news media in shaping firms' information environments and governance quality (e.g., Miller, 2006; Dyck, Volchkova, and Zingales, 2008; Bushee et al., 2010). According to Bushee et al. (2010), the business press is perhaps the broadest and most widely disseminated of all potential information intermediaries, reaching both sophisticated and unsophisticated investors, as well as managers, regulators, and other market participants. As such, the media's news coverage influences a firm's information environment over and above both firm-initiated disclosure and other information intermediaries (e.g., Tetlock, Saar-Tsechansky, and Macskassy, 2008). To the extent that the news media affects firms' information asymmetry, agency costs, and, particularly, the cost of capital (Kothari, Xu, and Short, 2009; Bushman, Williams, and Wittenberg-Moerman, 2017), it may also influence the cost of leverage adjustments. The media should therefore affect

\footnotetext{
${ }^{1}$ These adjustment costs include, for example, the transaction costs that firms incur when adjusting their debt-equity mix (e.g., Hennessy and Whited, 2007).
} 
the speed at which firms converge to their optimal capital structure. To date, however, the potentially important relationship between media coverage and corporate leverage adjustments has not been studied.

In this paper, we attempt to fill this gap in the literature by studying whether and how the media's news coverage affects firms' leverage adjustment speeds around the world. We develop two competing hypotheses based on the pros and cons of the media. The first hypothesis predicts that news coverage and content have a positive effect on firms' SOA toward leverage targets. Our prediction is guided by evidence of the bright side of the news media, namely, that the media can reduce firms' information asymmetry and act as their monitors. First, the media provides information to market participants through the timely and broad dissemination of news, which increases investor recognition and corporate visibility (Fang and Peress, 2009; Peress, 2014). Such dissemination of news stories can alleviate information asymmetry between firm managers and uninformed suppliers of capital. Hence, the media's news coverage can reduce the leverage adjustment costs caused by asymmetric information and increase the SOA toward leverage targets. We term this argument the information disseminating channel. Second, the media may undertake original investigations and analyses that provide new insights above and beyond the information supplied by the firm (e.g., Miller, 2006; Dyck, Morse, and Zingales, 2010). In this role, the news media can be considered a governance mechanism that helps alleviate the moral hazard problems associated with a firm's financial decisions. Close scrutiny by the media gives managers a strong incentive to pursue value-maximizing activities, i.e., to follow optimal capital structure policy by actively adjusting toward target leverage (Morellec, Nikolov, and Schurhoff, 2012). We call this argument the monitoring channel. 
The alternative hypothesis, which is based on the dark side of the media, argues that the news media may have no, or even a negative, impact on leverage adjustment speeds. This view is motivated by two arguments. First, the news media may not be effective at reducing firms' information asymmetry. The media may have incentives to publish sensational news that appeals to its readership at the expense of accuracy (Jensen, 1979; Core, Guay, and Larcker, 2008; Ahern and Sosyura, 2015). Such sensational and attention-grabbing news stories may not reduce information asymmetry and could lead to investor biases (Barber and Odean, 2008; Solomon, Soltes, and Sosyura, 2014). Second, the news media may not act as an effective corporate monitor. Greater news coverage and more positive news sentiment do not necessarily result in better corporate governance because they may be subject to managerial manipulation (Solomon, 2012; Ahern and Sosyura, 2014). Moreover, the media can exacerbate managerial myopia by placing market pressure on managers to meet short-term performance targets and forgo long-term valuemaximizing decisions (Dai, Shen, and Zhang, 2018). Taking these arguments together, media coverage may not reduce the financing frictions associated with information asymmetry and agency costs. Overall, the impact of the news media on leverage adjustments is ambiguous a priori and the question of what the impact is needs to be resolved empirically.

To test these opposing hypotheses, we use RavenPack News Analytics, a unique database of global news that provides real-time news releases at the firm level, and construct a large sample covering 33 countries over the $2000-2010$ period. To capture the different dimensions of the media's news coverage, we follow the literature (Dai, Parwada, and Zhang, 2015; Bushman, Williams, and Wittenberg-Moerman, 2017) and use two variables: the extent of news coverage and the tone of the news. The first variable proxies for the intensity of news coverage and captures the number of news articles written about a firm in a given year. The second variable proxies for the 
sentiment of news and reflects whether and to what extent a news event about a firm may have a positive, neutral, or negative effect on the firm's stock price.

Since our empirical analysis involves estimating dynamic capital structure models, it is important to use appropriate econometric techniques (Huang and Ritter, 2009). We follow recent research (Öztekin and Flannery, 2012; Öztekin, 2015; Çolak, Gungoraydinoglu, and Öztekin, 2018) and adopt a two-stage procedure. In the first stage, we estimate target leverage and obtain the deviation from that target. In the second stage, we estimate a partial adjustment model and examine the rate at which firms close out this leverage deviation and, particularly, whether the SOA varies with news coverage and sentiment.

Our baseline regressions show that firms with greater news coverage and more positive news sentiment have higher leverage SOAs. These results are robust to using alternative measures of leverage, including book and market leverage, as well as measures that are based on active leverage changes and unrelated to passive, mechanical leverage adjustments. They are also insensitive to different econometric methods, an alternative measure of news content, and subsamples of firms from countries with different institutional characteristics. Overall, our evidence lends strong support to the first hypothesis that news coverage and content help lower the leverage adjustment costs and hence increase the SOA.

A concern with our inferences is endogeneity. One source of endogeneity is the presence of unobserved heterogeneity (i.e., firm fixed effects), although this endogeneity concern should be addressed by the fixed-effects method used in our study. Omitted-variable bias and reverse causality pose yet more concerns. News coverage about a firm may be related to (time-varying) omitted industry- and firm-level factors that also affect the firm's capital structure adjustments, leading to a spurious correlation. Likewise, news stories about a firm may simply reflect changes 
in the firm's financial policies, including its leverage adjustments. We conduct several tests to address those concerns. First, we re-run our regressions for different types of news, particularly the news events discovered and analyzed by media reporters, or the non-financial news, which are less likely to be related to leverage adjustments. Second, we control for additional firm-, industry-, and country-level determinants of leverage adjustments that may be correlated with news coverage and content. Finally, we use national newspaper strikes as an exogenous shock to news coverage to examine the causal effect of the media on the leverage SOA. The results from these analyses suggest that news coverage and content facilitate leverage adjustments. Overall, while we cannot entirely rule out endogeneity, collectively these findings suggest that our main inference is unlikely to be driven by this potential problem.

We next examine two plausible channels underlying our first hypothesis. First, we explore the information disseminating channel. We argue that, if the positive effect of the media on the SOA is driven by the dissemination of corporate information to a wider audience, then this effect should be stronger (weaker) for firms with greater (lower) information asymmetry and/or firms operating in countries with less (more) transparent information environments. We use accounting standards (La Porta et al., 1998), disclosure score indices (Jin and Myers, 2006), and an aggregate measure of country-level asymmetric information (Öztekin and Flannery, 2012) to proxy for the country-level information environment. We use analyst coverage and Big 4 auditors as our proxies for firm-level information asymmetry. Consistent with our conjecture, we find support for the information dissemination channel: the positive effect of the news media on the SOA is generally less (more) pronounced for firms operating in countries with greater (lower) disclosure scores, accounting standards, or lower (greater) asymmetric information overall and for those with higher (lower) analyst coverage or that are (not) audited by a Big 4 auditor. 
Second, we investigate the monitoring channel. We reason that, if the media's news coverage helps increase firms' leverage adjustment speeds by enhancing the monitoring and governance mechanisms, then the effect of the media on the leverage SOA should be stronger (weaker) for more weakly governed (better-governed) firms and/or firms operating in countries with weaker (better) governance. To test this prediction, we adopt La Porta et al.'s (1998) legal origin and Kaufmann, Kraay, and Mastruzzi's (2011) regulatory and government effectiveness indices as proxies for country-level governance. We use institutional (block) ownership to measure firm-level corporate governance because institutional investors are more likely to monitor and discipline managers (Shleifer and Vishny, 1986; Aggarwal et al., 2011). We document evidence in support of the monitoring channel: the positive effect of the news media on leverage adjustment speeds is generally weaker (stronger) for firms with stronger (weaker) governance, i.e., for firms with higher (lower) institutional ownership or block ownership, or firms operating in countries with common law (other legal traditions), stronger (weaker) regulatory quality, or higher (lower) governance effectiveness.

In our final set of analyses, we show that the impact of news coverage and content on the SOA is more pronounced for firms operating in environments with higher costs and/or lower benefits of leverage adjustment. This finding is in line with our key argument that the media facilitates leverage adjustments, leading to higher SOAs. Furthermore, we find that news coverage and sentiment are positively related to firms' propensity to access external capital markets and undertake leverage adjustments, mainly through equity issuances, debt issuances, and debt reductions.

Our study contributes to the literature in several ways. To the best of our knowledge, we are the first to examine the effect of the news media on firms' dynamic leverage adjustments. Our 
study provides novel cross-country evidence on the positive and significant role played by the news media in determining firms' optimal capital structure decisions. The second novelty of our study lies in the use of an international dataset of global news from RavenPack News Analytics. Using this comprehensive and unique data enables us to exploit the rich variation in firm-level news coverage and content, leverage ratios, and country-level institutional characteristics, thus allowing a better understanding of the interactions between the news media and firms' leverage SOA, as well as the role of institutional factors.

Our study adds to the capital structure literature. Recent research has examined various determinants of dynamic leverage adjustments. At the firm level, a firm's SOA toward its target leverage is influenced by the deviation from that target and the firm's financing needs (Byoun, 2008), cash flow features (Faulkender et al., 2012), and equity mispricing (Warr et al., 2012). At the macro and country level, the leverage SOA is determined by the state of the economy and the business cycle (Cook and Tang, 2010; Halling, Yu, and Zechner, 2016), as well as the institutional environment (Öztekin and Flannery, 2012). ${ }^{2}$ Adding to this strand of research, we propose news coverage and content as a new and important factor affecting leverage adjustment speeds. We further demonstrate that the effect of the media on the leverage SOA is over and above the impacts of several firm- and country-level determinants of the SOA.

Our study also contributes to a growing strand of research that links the news media to the corporate sector. This literature suggests that the media plays an important role in shaping firms'

\footnotetext{
${ }^{2}$ The literature has also studied many other non-media determinants of the SOA (e.g., Elsas and Florysiak, 2011; Dang, Kim, and Shin, 2012; Fier, McCullough, and Carson, 2013; Chang, Chou, and Huang, 2014; Lockhart, 2014; An, Li, and Yu, 2015; Liao, Mukherjee, and Wang, 2015; Zhou et al., 2016; Brisker and Wang, 2017; Devos, Rahman, and Tsang, 2017; Jiang et al., 2017; Çolak, Gungoraydinoglu, and Öztekin, 2018).
} 
information environments and financial decisions. For example, the media can reduce information asymmetry (Bushee et al., 2010), affect the cost of equity capital (Kothari, Xu, and Short, 2009), detect accounting fraud (Miller, 2006), improve governance structures (Dyck, Volchkova, and Zingales, 2008), monitor CEO compensation (Core, Guay, and Larcker, 2008; Kuhnen and Niessen, 2012), affect board quality and effectiveness (Joe, Louis, and Robinson, 2009), influence capital allocation decisions (Liu and McConnell, 2013), reduce insider trading profits (Dai, Parwada, and Zhang, 2015), affect stock price synchronicity (Dang, Moshirian, and Zhang, 2015), and influence syndicated loan formation and pricing (Bushman, Williams, and WittenbergMoerman, 2017). This line of research, however, provides little insight into the effect of the media on corporate capital structure. Our study shows that the media helps increase the speed with which firms converge toward target leverage, thus contributing positively to optimal capital structure decisions and shareholder wealth maximization. Finally, our evidence of the positive role of news media coverage also adds to a broader debate on the advantages and disadvantages of the media in the economy and wider society (e.g., Clarke et al., 2018).

The paper proceeds as follows. Section 2 presents a brief review of the related literature and develops the main hypotheses. Section 3 discusses empirical models and methodologies. Section 4 describes data and variable construction and provides summary statistics. Section 5 presents the baseline results and robustness tests, whereas Section 6 addresses endogeneity issues. We explore possible underlying economic mechanisms in Section 7 and perform additional analyses in Section 8. Section 9 concludes the paper. 


\section{Related Literature and Hypotheses Development}

\subsection{Dynamic Leverage Adjustments}

Following on from Modigliani and Miller's (1958) seminal work, a large body of research has focused on testing one of the most dominant views of capital structure, namely, the trade-off theory. This strand of research has theoretically and empirically addressed several important questions: Do firms have an optimal capital structure or leverage target? How quickly do they move toward those targets? Finally, what are the impediments to achieving those targets? ${ }^{3}$ According to the existing trade-off models (Fischer, Heinkel, and Zechner, 1989; Goldstein, Ju, and Leland, 2001; Strebulaev, 2007), firms identify a time-varying leverage target that optimally balances various benefits (e.g., tax savings, mitigated manager-shareholder agency costs) and costs (e.g., financial distress and bankruptcy costs, stockholder-bondholder agency conflicts) of debt. Empirically, most existing studies support this view, as they show that firms generally have leverage targets and attempt to move toward those targets in the long run (e.g., Flannery and Rangan, 2006; Antoniou, Guney, and Paudyal, 2008; Byoun, 2008; Huang and Ritter, 2009).

A recent strand of the capital structure literature has examined whether and how target adjustment behavior is determined by the magnitude of the adjustment costs (transaction costs), which are related to agency and adverse selection problems. Specifically, Leary and Roberts (2005) find that costly leverage adjustment significantly influences the dynamic rebalancing of capital

\footnotetext{
${ }^{3}$ Another predominant view of capital structure is the pecking order theory, which posits that firms follow a financing hierarchy due to the adverse selection costs associated with information asymmetry (Myers, 1984; Myers and Majluf, 1984). See Frank and Goyal (2008), Parsons and Titman (2009), and Graham and Leary (2011) for excellent reviews of the capital structure literature.
} 
structure. Goldstein, Ju, and Leland (2001) and Strebulaev (2007) further show that firms with higher transaction costs tend to adjust their capital structures less frequently. DeAngelo, DeAngelo, and Whited (2011) also find that firms may move toward target leverage quite slowly as they use transitory debt to fund investment.

Empirically, existing studies have documented a number of factors affecting leverage adjustment costs, and hence, the leverage SOA. At the firm level, Byoun (2008), Faulkender et al. (2012), and Elsas, Flannery, and Garfinkel (2014) find that the deviation from target leverage, combined with financing needs, cash flow realizations, and large investments financed through security issuances, affect the speed with which firms approach target leverage. Warr et al. (2012) show that equity mispricing, which is a temporary deviation of a firm's share price from its fundamental value, affects the firm's leverage SOA. At the macro or country level, Cook and Tang (2010) show that firms adjust their leverage toward the target level faster under better macroeconomic conditions, while Halling, Yu, and Zechner (2016) document that leverage adjustment speeds depend on business cycles. Likewise, Öztekin and Flannery (2012) find that the transaction costs associated with a firm's leverage adjustments are lower when the firm operates in a better institutional environment. Öztekin (2015) further finds that the quality of country-level institutions is positively related to leverage adjustment speeds. We note, however, that this stream of research has not studied whether and how the media's news coverage and content affect capital structure adjustments.

\subsection{News Media and Leverage Adjustments: Hypotheses}

Based on recent studies of the roles of the media in financial markets and corporate policies, we develop two competing hypotheses regarding the impact of the media on firms' leverage adjustments. The first predicts that news coverage and content have a positive effect on the 
leverage SOA. This prediction is inspired by the positive role played by the media in shaping corporate behaviors. First, the information disseminating channel suggests that, through the dissemination of information to a wider audience, the media can help increase investor recognition and corporate visibility and, thus, reduce information asymmetry between informed managers and uninformed market participants (Korajczyk, Lucas, and McDonald, 1991; Fang and Peress, 2009; Tetlock, 2010; Blankespoor, Miller, and White, 2014; Peress, 2014; Turner, Ye, and Walker, 2018). Tetlock, Saar-Tsechansky, and Macskassy (2008) further argue that the media can play an informational role because the linguistic media content and sentiment can capture otherwise hardto-quantify information about firms' fundamentals. In line with these arguments, Bushee et al. (2010) find that the business press helps decrease the information asymmetry around earnings announcements. Drake, Guest, and Twedt (2014) show that press coverage of annual earnings announcements mitigates cash flow mispricing. Kothari, Xu, and Short (2009) find that the tone of news in the business press is associated with cash flow risk and information asymmetry and, therefore, affects the cost of equity and stock return volatility. Bushman, Williams, and WittenbergMoerman (2017) further show that positive news sentiment reduces adverse selection and improves lenders' assessments of firm quality, thus affecting their decisions to originate, join, and structure syndicated loans, and the cost of these loans. Overall, the above studies suggest that greater media coverage and more positive news sentiment reduce firms' information asymmetry and financing frictions, thus facilitating leverage adjustments.

Moreover, the monitoring channel argues that the media can serve a monitoring role by both creating news content and disseminating the news content generated by other information intermediaries (Miller and Skinner, 2015). Through original investigations and analyses, the media may provide new insights over and above the information disclosed by the firm. Empirically, Dyck 
and Zingales (2002) find that the news media can drive politicians to reform or enforce corporate laws. Miller (2006) and Dyck, Morse, and Zingales (2010) show that the media may act as an effective monitoring mechanism by providing early detection of corporate fraud. Dyck, Volchkova, and Zingales (2008) also document that greater media coverage increases the probability that a corporate governance violation will be reversed. Kuhnen and Niessen (2012) find that the media helps monitor CEO compensation practices while Dai, Parwada, and Zhang (2015) show that news coverage both monitors and reduces insider trading profits. Liu and McConnell (2013) further find that the media heightens the impact of value-reducing acquisitions on managers' reputational capital, consistent with the idea that the media helps align managers' interests with those of shareholders. Bednar (2012) also argues that because firms with better governance (e.g., more board independence) attract more favorable media coverage, more positive news may reflect better governance quality. Overall, these studies suggest that monitoring by the news media can alleviate agency costs, which in turn should facilitate firms' optimal capital structure decisions (Morellec, Nikolov, and Schurhoff, 2012).

Taking the above arguments together, we argue that the news media can lower a firm's adjustment costs by mitigating its information asymmetry and agency conflicts. The media's news coverage and content should enable firms to adjust more quickly toward their target leverage. Hence, we formulate our first hypothesis as follows:

H1a: Greater news coverage and more positive news sentiment are associated with greater leverage SOAs.

However, the alternative, and more skeptical, view is that the media may not have a positive effect on firms' leverage adjustment, or that it may even impede such adjustment. Specifically, if the media is only effective in news distribution, news coverage will simply repeat firm-initiated 
news stories, without adding new information content. Alternatively, the information content of news may not reach a broader class of investors than that already reached by other information intermediaries. In either case, the media will be unlikely to improve firms' information environments and governance quality. Furthermore, some research suggests that the media has an incentive to sensationalize news, even at the expense of accuracy, to appeal to its readership (Jensen, 1979; Core, Guay, and Larcker, 2008; Ahern and Sosyura, 2015). If the media publishes sensational news stories, particularly those with a negative tone (Green, Hand, and Penn, 2014), it may not help reduce firms' information asymmetry. Indeed, the media's news coverage may lead to inefficient trading behavior and investor biases (Frankel and Li, 2004; Barber and Odean, 2008; Solomon, Soltes, and Sosyura, 2014). ${ }^{4}$ Likewise, greater news coverage and more positive news sentiment do not necessarily indicate better monitoring and governance because they may be influenced by managerial control and manipulation (Gurun and Butler, 2012; Solomon, 2012; Solomon and Soltes, 2012; Ahern and Sosyura, 2014; Blankespoor and DeHaan, 2015; DeHaan, Shevlin, and Thornock, 2015). On the other hand, the media can also impose excessive pressure on managers, forcing them to meet short-term earnings targets rather than pursue long-term valueenhancing innovative projects (Dai, Shen, and Zhang, 2018). Alternatively, favorable news coverage provides management with a buffer against external pressure and increases their overconfidence and hubris, thus reinforcing their current behavior, enhancing their discretion, and overall exacerbating agency conflicts (Hayword et al., 2004; Bednar, 2012).

\footnotetext{
${ }^{4}$ Alternatively, if the media focuses excessively on negative news, it may lead to higher financing costs for firms, even when the news helps reduce information asymmetry.
} 
The above discussions suggest that news coverage may not always reduce the leverage adjustment costs associated with information asymmetry and agency problems. The implication is that the media may have an insignificant, or even negative, impact on the leverage SOA. We propose the following hypothesis to reflect this view:

H1b: Greater news coverage and more positive news sentiment are not associated with greater leverage SOAs.

\section{Empirical Models and Methods}

\subsection{Partial Adjustment Model of Leverage}

Prior research models firms' adjustments toward their target leverage using the following partial adjustment process (Faulkender et al., 2012; Flannery and Rangan, 2006; Öztekin and Flannery, 2012):

$$
\Delta L E V_{i j, t+1} \equiv L E V_{i j, t+1}-L E V_{i j, t}=\alpha+\delta\left(L E V_{i j, t+1}^{*}-L E V_{i j, t}\right)+e_{i j, t+1},
$$

where $L E V_{i j, t+1}^{*}$ and $L E V_{i j, t+1}$ respectively denote the target and actual (observed) leverage ratios

for firm $i$, country $j$ in period $t+1$. $e_{i j, t+1}$ is the error term. $L E V_{i j, t+1}^{*}-L E V_{i j, t}$ is often termed the deviation from target leverage; we denote this term $D L E V_{i j, t}$.

Equation (1) models the actual leverage adjustment $\left(\Delta L E V_{i j, t+1}\right)$ made by the firm between periods $t$ and $t+1$ as a fraction of the desired change $\left(D L E V_{i j, t}=L E V_{i j, t+1}^{*}-L E V_{i j, t}\right)$ that the firm would make if it were to move all the way to its target leverage in that period. The coefficient $\delta$ is the leverage SOA, which measures how quickly firms adjust toward their target leverage in the presence of positive adjustment costs. The SOA is expected to lie between zero and one, with a higher value indicating a more rapid adjustment in line with the prediction of the dynamic tradeoff framework. 
Although in Equation (1) the target leverage ratio, $L E V_{i j, t+1}^{*}$, is not directly observed, it is typically modeled as a function of some determining factors, as follows:

$$
L E V_{i j, t+1}^{*}=\boldsymbol{\theta}^{\prime} \boldsymbol{X}_{i j, t}+\mu_{i}
$$

In this model, we follow prior research (e.g., Frank and Goyal, 2009; Öztekin and Flannery, 2012; Öztekin, 2015) and include in vector $\boldsymbol{X}_{i j, t}$ the most relevant firm-, industry-, and country-specific determinants of capital structure, namely profitability $(R O A)$, market-to-book $(M B)$, non-debt tax shields $(D E P)$, firm size (SIZE), asset tangibility (TANG), research and development $(R \& D)$ expenditures, an R\&D dummy ( $R \& D D)$, effective tax rate (TAX), liquidity (LIQUID), the industrymedian leverage ratio (INLEV) (based on the industry classification benchmark (ICB)), the inflation rate (INFL), and the GDP growth rate $(G G D P)$. To alleviate omitted-variable bias, we further include in $\boldsymbol{X}_{i j, t}$ the news variables. $\boldsymbol{\theta}$ is a vector of the corresponding coefficients. Since a large amount of variation in corporate leverage is explained by time-invariant, unobservable firmspecific factors (Lemmon, Roberts, and Zender, 2008), we also include firm fixed effects $\left(\mu_{i}\right)$ in the model. We note that by modeling target leverage in period $t+1$ as a function of the determining factors observed in period $t$, we are able to mitigate endogeneity concerns relating to those factors.

In estimating the SOA for each country in the partial adjustment model (1), we substitute target leverage, $L E V_{i j, t+1}^{*}=\boldsymbol{\theta}^{\prime} \boldsymbol{X}_{i j, t}+\mu_{i}$ from Equation (2) into Equation (1), and rearrange to yield the following dynamic panel data model:

$$
L E V_{i j, t+1}=\alpha+(1-\delta) L E V_{i j, t}+\boldsymbol{\vartheta}^{\prime} \boldsymbol{X}_{i j, t}+\mu_{i}+e_{i j, t+1},
$$

where $\boldsymbol{\vartheta}^{\prime}=\delta \boldsymbol{\theta}^{\prime}$. We estimate Equation (3) for each of the 33 countries in our sample to obtain the (country-specific) estimates of the leverage $\mathrm{SOA}, \delta$, and those of the coefficients on the determinants of target leverage. Importantly, based on those estimates and Equation (2), we can 
estimate target leverage, $\widehat{L E V}_{i j, t+1}^{*}$, and subsequently the deviation from the target leverage, $D L E V_{i j, t}=L \widehat{L V}_{i j, t+1}^{*}-L E V_{i j, t} .^{5}$

\subsection{The Impact of News Coverage on the Speed of Leverage Adjustment}

According to our hypotheses, the leverage SOA in Equation (3) is determined by the media's news coverage. We thus model this economic relation as follows:

$$
\delta_{i j, t}=\boldsymbol{\beta}^{\prime} N E W S_{i j, t}+\boldsymbol{\gamma}^{\prime} \boldsymbol{Z}_{i j, t}
$$

where $N E W S_{i j, t}$ is a vector of the news variables proxying for different dimensions of the media's news coverage, as discussed in detail in Section 4.2.1. $\boldsymbol{Z}_{i j, t}$ is a vector of several relevant firm-, industry-, and country-level determinants of the leverage SOA. First, we control for two dummy variables that capture whether firms are over- or under-levered relative to target leverage (OVER), and/or whether they have a financing deficit or surplus $(D E F)$. Recent research shows that deviation from target leverage (Byoun, 2008) and cash flow status (Faulkender et al., 2012) are among the most important determinants of the cost and speed of leverage adjustment. Second, we control for industry fixed effects because both news coverage and the leverage SOA vary significantly across industries (Fang and Peress, 2009; Elsas and Florysiak, 2011). Third, we control for macroeconomic conditions as they may affect firms' leverage adjustments (Cook and Tang, 2010; Halling, Yu, and Zechner, 2016). Specifically, following Cook and Tang (2010), we

\footnotetext{
${ }^{5}$ Our results suggest that news coverage and sentiment are either positively or negatively associated with target leverage. One possible explanation for this mixed finding is the potentially different roles (i.e., bright side or dark side) played by the media, as articulated in our hypothesis development (Section 2.2). Alternatively, the media may reduce both the cost of debt and equity, allowing firms to increase their use of debt, equity, or both; in such cases, the impact of the media's news on target leverage is theoretically ambiguous.
} 
include dividend yields $(D Y)$ and GDP growth $(G G D P)$. Fourth, we add year and country fixed effects to allow for the possibility that the SOA varies over time and across countries. In our robustness checks, we control for many other macro- and firm-level variables.

Next, substituting Equation (4) into Equation (1), we obtain the following model:

$$
\Delta L E V_{i j, t+1}=\alpha+\left(\boldsymbol{\beta}^{\prime} N E W S_{i j, t}+\boldsymbol{\gamma}^{\prime} \boldsymbol{Z}_{i j, t}\right) D L E V_{i j, t}+e_{i j, t+1}
$$

which can be written as

$$
\Delta L E V_{i j, t+1}=\alpha+\boldsymbol{\beta}^{\prime}(N E W S \times D L E V)_{i j, t}+\boldsymbol{\gamma}^{\prime}(\boldsymbol{Z} \times D L E V)_{i j, t}+e_{i j, t+1} .
$$

The effect of the media on the SOA is thus captured by the coefficients $(\boldsymbol{\beta})$ on the interaction terms between the news media and the deviation from target leverage, $(N E W S \times D L E V)_{i j, t}$. We note that our model also includes several interaction terms $(\boldsymbol{Z} \times D L E V)_{i j, t}$ between the deviation from target leverage and a vector of the controls that contain several fixed effects listed above

To summarize, as in recent research (e.g., Öztekin and Flannery, 2012; Öztekin, 2015), we adopt a two-stage procedure to examine the impact of news media coverage on the leverage SOA. In the first stage, we estimate Equation (3) and obtain target leverage, $L \widehat{E V}_{i j, t+1}^{*}$, and the deviation from that target, $D L E V_{i j, t}=L \widehat{E V}_{i j, t+1}^{*}-L E V_{i j, t}$. We note that, because Equation (3) is a dynamic panel data model, using the traditional pooled OLS or fixed effects (FE) estimators would lead to biased and inconsistent estimates; see Baltagi (2013) for a detailed review. ${ }^{6}$ We thus follow Flannery and Hankins (2013) and adopt the Blundell and Bond (1998) (two-step) system

\footnotetext{
${ }^{6}$ There is a correlation between the firm fixed effects and the dynamic term, $L E V_{i j, t}$, that results in a bias. Thus, OLS tends to underestimate the SOA while FE overestimates the SOA. The bias tends to be quite severe if the sample has a relatively small number of time periods, as ours does (Judson and Owen, 1999).
} 
generalized method of moments (SYSGMM). ${ }^{7}$ In our robustness check, we use another recently advanced method to estimate this model.

In the second stage, we estimate Equation (6) by regressing the observed change in leverage, $\Delta L E V_{i j, t+1}$, on the interaction terms between the (estimated) deviation from target leverage and the news variables, $(N E W S \times D L E V)_{i j, t}$ and those between this deviation and the determinants of the leverage SOA listed above, $(\boldsymbol{Z} \times D L E V)_{i j, t}$. As in recent research (e.g., Öztekin and Flannery, 2012; Öztekin, 2015), we estimate this model using pooled ordinary least squares (POLS). However, in a robustness check, we employ the FE estimator to control for timeinvariant unobserved firm-specific factors that may be correlated with the news variables and the leverage SOA. Since $D L E V_{i j, t}$ is generated from the first stage rather than observed, the estimation in the second stage is subject to the well-known generated regressors problem, in which the estimated standard errors may be incorrect (Pagan, 1984). We address this problem by estimating bootstrapped standard errors (Faulkender et al., 2012; Öztekin, 2015).

We acknowledge that our estimation approach based on the partial adjustment model is not without potential shortcomings. First, this model may capture potential mechanical mean reversion and have low test power since leverage only varies within the unit interval and tends to move toward the mean in the long run (Chang and Dasgupta, 2009). We address this issue in a robustness test focusing on active leverage adjustments, rather than passive, mechanical ones. Still, even after

\footnotetext{
${ }^{7}$ In applying this method, we estimate our model in both levels and first differences using appropriate instruments for the dynamic term. Specifically, in the level equations, our instruments for $L E V_{i j, t}$ include its lagged values in first differences. In the first-differenced equations, our instruments for $\Delta L E V_{i j, t}$ are the lagged values of $L E V_{i j, t}$, both in levels. We use Roodman's (2009) Stata code xtabond2 to perform the regressions.
} 
accounting for this issue, evidence shows that firms adjust at moderate rates, suggesting that the leverage SOA may not be important enough to be a first-order policy determinant (Fama and French, 2002; Baker and Wurgler, 2002; Welch, 2004; Graham and Leary, 2011). Second, the partial adjustment framework relies on the idea that firms adjust their capital structure based on a comparison of target leverage in period $t$ with observed leverage in $t-1$. This is arguably a strong assumption as optimal policy may take into account initial leverage and refinancing thresholds, as well as the effects of future investment and financing decisions (Çolak, Gungoraydinoglu, and Öztekin, 2018). To address this critique, our study focuses on how the SOA varies with news coverage and sentiment rather than the absolute value of the SOA. In additional tests, we supplement our main analysis with evidence on firms' security issuances and retirements/repurchases (Öztekin, 2015; Çolak, Gungoraydinoglu, and Öztekin, 2018). This latter approach is free from the above concerns regarding the partial adjustment model.

\section{Data and Variable Construction}

\subsection{Sample}

We collect data from several sources. Firm-level media news data are drawn from RavenPack News Analytics. Accounting data come from Worldscope. Data on analyst coverage are taken from the Institutional Brokers' Estimate System (I/B/E/S). Big 4 auditor appointment data come from Compustat Global and Worldscope. At the country level, the data include both time-invariant variables, drawn from the existing literature, and time-varying variables, obtained from the World Development Indicators. Appendix A provides variable definitions and data sources in detail. All continuous variables are winsorized at the $1^{\text {st }}$ and $99^{\text {th }}$ percentiles to alleviate the impact of outliers. 
Our initial sample includes all firms across 33 countries during the period 2000-2010 that have media news data. We retain only firms with common stock and exclude those with special features, such as ADRs (American Depository Receipts), GDRs (Global Depository Receipts), warrants, trusts, funds, and non-equity securities. We also focus on firms listed on the single major exchange of each country, making exceptions for China (Shanghai Stock Exchange and Shenzhen Stock Exchange), Japan (Tokyo Stock Exchange and Osaka Stock Exchange), and the U.S. (American Stock Exchange and New York Stock Exchange), which have two exchanges of equal importance. ${ }^{8}$ We exclude financial and utility firms because these firms are subject to special regulations on financing policies. For a firm to be included in the analysis where we use dynamic panel data models, we also require the firm to have data for all variables for at least two years. These screening procedures result in a final sample of 6,778 firms with 33,619 firm-year observations. Table IA.1 in our internet appendix provides information on the data structure.

\subsection{Variable Construction}

\subsubsection{Media News Variables}

We obtain media news data from RavenPack News Analytics, a leading global news database commonly used in algorithmic trading and increasingly in the finance and accounting literature (e.g., Dai, Parwada, and Zhang, 2015; Dang, Moshirian, and Zhang, 2015; Bushman, Williams, and Wittenberg-Moerman, 2017). RavenPack continuously analyzes relevant economic and business information at both the country and firm levels from all leading global media

\footnotetext{
${ }^{8}$ NASDAQ is a multiple-dealer market and its multiple trades based on the same order may result in a structural difference in the information asymmetry for firms listed in this market (e.g., Lai, Ng, and Zhang, 2014). However, our results (untabulated) still hold when NASDAQ firms are included in the sample.
} 
organizations, major real-time newswires, online media, and trustworthy sources, including Dow Jones Newswires, all editions of the Wall Street Journal, Barron's, other major publishers and Web aggregators, regional and local newspapers, blog sites, press releases, regulatory disclosures, and government and regulatory updates, to produce real-time news analytics. RavenPack processes news flows (i.e., news coverage) and the information content of news articles (i.e., news-sentiment score) for more than 34,000 firms across 200 countries. The database covers over $98 \%$ of the investable global market, capturing news covering a wide range of facts, opinions, and firm disclosures.

To measure the information content of a news article, RavenPack uses three proprietary methodologies: traditional language analysis, expert consensus, and market response. These three methodologies produce a major type of sentiment score, an event sentiment score (ESS), which indicates the value effect of an entity-specific news event. To identify the ESS, RavenPack first uses an internal taxonomy to classify a news article into one of a set of predefined event categories that could be fundamental to investments. RavenPack then analyzes news events using sentiment analysis techniques to identify a quantified sentiment score for each news event. The ESS is determined based on training sets in which financial experts have classified firm-specific events and agreed on whether these events generally convey a positive, neutral, or negative sentiment and to what degree. The sentiment score has a value ranging between zero and 100, with a value above (or below) 50 indicating the positive (or negative) sentiment of a given news event, and a value of 50 representing a neutral sentiment. This score is assigned to all firms that are related to the reported news event. In our empirical analysis, we apply a transformation to the ESS score so that its value varies between -1 and 1. Positive, negative, and zero values respectively indicate positive, negative, and neutral sentiment for a particular news event. 
Based on the information provided by RavenPack reviewed above, we construct two measures of the news provided by the media: (1) the breadth (extent) of news coverage (NewsCove) and (2) the sentiment (tone) of news (NewsTone). NewsCove is the natural logarithm of one plus the number of news articles that cover news events for a firm in a given year. NewsTone is the average of the news-sentiment (ESS) scores for a firm in a given year. NewsCove and NewsTone capture two distinct dimensions of news. As such, a positive news tone does not necessarily imply more or less news coverage, and vice versa.

\subsubsection{Leverage Variables}

Since finance theory and empirical work testing trade-off models typically focus on market-based debt ratios (e.g., Hovakimian, Opler, and Titman, 2001; Leary and Roberts, 2005; Flannery and Rangan, 2006), our main measure of leverage is market leverage (MLEV). This variable is defined as the book value of total debt divided by the sum of the market value of equity and the book value of total debt. Nevertheless, following recent research (e.g., Faulkender et al., 2012), we also consider book leverage (BLEV) to be an alternative measure and check the robustness of our results to this measure. Book leverage is calculated as the book value of total debt divided by the book value of total assets.

\subsubsection{Summary Statistics}

Table 1 presents the summary statistics for each country and for the entire sample. On average, across the entire sample, a firm has a book leverage ratio of 0.22 and a market leverage ratio of 0.18 . In terms of the news variables, the means of news coverage and news tone are 3.02 and 0.10 , respectively. Firms in the U.S. receive the largest amount of news coverage (4.32), followed by those in Canada (3.35), Russia (3.10), and the U.K. (2.97). An average firm in the sample has total assets (book value) of $\$ 946$ million, an asset tangibility ratio of 0.32 , a market- 
to-book ratio of 1.71 , a liquidity ratio of 0.48 , an $R \& D$ ratio of 0.02 , a depreciation ratio of 0.04 , and an effective tax rate of $17.6 \%$.

[Insert Table 1 here]

\section{Results and Discussion}

\subsection{Baseline Regression Results}

Table 2 presents the baseline regression results for Equation (6). Our independent variables of interest are the interactions between the deviation from target leverage and (1) the extent of news coverage (NewsCove $\times D L E V)$ and (2) the tone of the news (NewsTone $\times D L E V)$. We find that the coefficients on these interaction terms are positive and highly significant at the $1 \%$ level in Models (1)-(4). These terms also remain significantly positive in Models (5) and (6), when we consider them in the same regressions to examine the joint effects of the news variables on leverage adjustments. These results, taken together, indicate that the extent of news coverage and the tone of the news are positively associated with the leverage SOA. Moreover, the effect of the news variables on the leverage SOA is economically significant. Based on the results for Models (5) and (6), a one standard deviation (1.293) increase in NewsCove will lead to an increase of 7.2-12.8 percentage points in the SOA. The impact of news tone is slightly more pronounced: the SOA will increase by $11.8-13$ percentage points if NewsTone increases by one standard deviation $(0.215) .{ }^{9}$ Overall, the results lend strong support to hypothesis H1a that news coverage and content help increase the speed with which firms move toward their target leverage. However, they do not

\footnotetext{
${ }^{9}$ This impact is economically relevant considering that SOA estimates documented by recent research (Öztekin and Flannery, 2012) and the current study (see our internet appendix, Table IA.1) typically vary between $20 \%$ and $40 \%$.
} 
support the alternative view, $\boldsymbol{H} \boldsymbol{1 b}$.

[Insert Table 2 here]

Regarding the control variables, we find that most of the results are in line with prior literature (e.g., Cook and Tang, 2010; Byoun, 2008; Faulkender et al., 2012). Specifically, the coefficients on $O V E R \times D L E V$ are positive and significant in almost all models, suggesting that over-levered firms have higher leverage SOAs. The coefficients on $D E F \times D L E V$ are also positive and significant in almost all models, indicating that firms with a financial deficit have higher leverage SOAs. The latter finding is consistent with prior research (e.g., Dang, Kim, and Shin, 2012) and suggests that firms under more pressure and/or with more incentive to cover their financing deficit undertake quicker adjustment. The coefficients on $D Y \times D L E V$ are negative in some models while the coefficients on $G D P \times D L E V$ are always significantly positive. These results suggest that the leverage SOA becomes lower during economic contractions (i.e., with high dividend yields) and higher during economic expansions (i.e., with high GDP growth), which is consistent with the literature (e.g., Cook and Tang, 2010).

\subsection{Robustness Checks}

We next examine the robustness of our results to using (1) alternative measures of leverage, (2) an alternative econometric method, and (3) an alternative measure of media news.

\subsubsection{Alternative Measures of Leverage}

According to Faulkender et al. (2012), a firm's leverage change can be decomposed into two components: a passive, mechanical adjustment and an active one; an active leverage adjustment occurs when the firm visits capital markets in some way. The authors further argue that, because only active adjustments entail transaction costs as predicted by dynamic trade-off models,

tests of target adjustment behavior should examine the active adjustment component. Following 
this argument, in our first robustness check we use measures of leverage that focus on active leverage adjustments. We note that this analysis also helps address the concern that the SOA estimates could be biased due to the presence of passive, mechanical adjustment.

We modify Equation (1) to focus on active leverage adjustment as follows:

$$
\begin{aligned}
\Delta L E V_{i j, t+1} \equiv L E V_{i j, t+1}-L E V_{i j, t}^{P} & =\alpha+\delta\left(L E V_{i j, t+1}^{*}-L E V_{i j, t}^{P}\right)+e_{i j, t+1}, \\
L E V_{i j, t}^{P} & =\frac{L E V_{i, t-1}}{T A_{i, t-1}+N I_{i, t}},
\end{aligned}
$$

where $T A$ is the book value of total assets, and $N I$ is net income during the year. The left-hand side of Equation (7) captures the firm's active adjustment toward its target leverage. We re-estimate a modified specification of Equation (6) that uses $L E V_{i j, t}^{P}$ instead of $L E V_{i j, t}$. The results, reported in Models (1) and (2), Panel A of Table 3, are qualitatively similar to the baseline findings. The effects of news coverage and sentiment on the SOA are positive and statistically significant. In short, our main finding is robust to the alternative leverage measures that only capture active adjustments.

[Insert Table 3 here]

\subsubsection{Alternative Econometric Method}

Although we use SYSGMM to estimate target leverage and the deviation from target leverage in our main analyses, in the robustness check below we consider a newly proposed method for dynamic panel data models with fractional dependent variables, termed DPF (Loudermilk, 2007; Elsas and Florysiak, 2015). This method resembles a Tobit estimator, in which the latent dependent variable can take values that are outside the unit interval but doubly censored at the corner outcomes, zero and one. An additional important feature of this approach is that the distribution of the unobserved fixed effects is assumed to be conditional on the initial value of the dependent variable and the time averages of the exogenous explanatory variables (Wooldridge, 2005); in essence, this modeling choice allows for firm heterogeneity. Dang, Kim, and Shin (2015) 
and Elsas and Florysiak (2015) demonstrate that DPF can outperform other alternative estimators when estimating dynamic leverage models. ${ }^{10}$

Models (3)-(4) of Panel A, Table 3 report the results when DLEV is obtained using DPF rather than SYSGMM. The coefficients on NewsCove $\times D L E V$ and NewsTone $\times D L E V$ are positive and statistically significant at the $1 \%$ level, suggesting that our evidence of a positive relation between news media coverage and the SOA still holds when using this estimation method.

\subsubsection{Alternative Measure of Media News}

Following Dang, Moshirian, and Zhang (2015), we consider an alternative measure of news content: firm-specific information in news stories (NewsFirm). NewsFirm is the logistic transformation of $R^{2}$ values (i.e., $\log \left(\left(1-R^{2}\right) / R^{2}\right)$ ), which are estimated each year from a firm's weekly news-sentiment scores regressed on a given country's weekly news-sentiment scores, as a measure of the firm-specific information contained in news stories. The intuition behind this measure is that, if the firm's news events have less market-wide information content than the firmspecific fundamentals, then the media's production of information about the firm is more firmspecific. In Models (1) and (2), Panel B of Table 3, we report the results using NewsFirm as the only media news variable. In Models (3) and (4), we include all three media news variables, namely, NewsCove, NewsTone, and NewsFirm. The results show that the coefficients on the interactions between the news variables and the deviation from target leverage are all positive and

\footnotetext{
${ }^{10}$ Elsas and Florysiak (2015) further argue that using the DPF estimator may help mitigate the concern that the estimate of the SOA could be confounded by mechanical mean reversion since leverage only varies within the unit interval and tends to move toward the mean in the long run (Chang and Dasgupta, 2009).
} 
statistically significant, suggesting that the positive effect of news coverage and content on the leverage SOA is robust to using this alternative measure of media news. ${ }^{11}$

\subsubsection{Additional Robustness Checks}

Next, we perform several analyses to further demonstrate the robustness of our main findings. To conserve space, we report these results in the internet appendix. We first control for differences in the institutional characteristics of the countries in our sample. Specifically, we run a subsample analysis for U.S. versus non-U.S. firms. We further re-run our regressions separately for firms from developed economies and those from emerging markets, as well as those from highand low-press-freedom countries. The results in Table IA.2 continue to show positive and significant coefficients on the interaction terms between the news variables and leverage deviation. This finding indicates that the positive impact of news coverage and content on leverage adjustment speeds persists after controlling for differences in institutional factors.

Although we employ the two-stage estimation approach in our main analysis, we also consider the one-stage approach (Elsas and Florysiak, 2015; Halling, Yu, and Zechner, 2016). This latter approach involves estimating an augmented partial adjustment model based on Equation (3) that includes interaction terms between lagged leverage and the news variables. It requires the use of advanced methods for estimating dynamic panel data such as SYSGMM. The results, reported in Table IA.3, show that our results are robust to using this approach.

\footnotetext{
${ }^{11}$ Although the coefficients on firm-specific news are relatively small in magnitude, we note that this variable is scaled differently compared to the other news and macroeconomic variables (see Appendix A for detailed variable definitions). In further analysis, we estimate standardized coefficients and find that the economic impact of the news variables is generally greater than that of the institutional factors.
} 


\section{Addressing Endogeneity Issues}

We address potential endogeneity concerns by focusing on certain types of news that are plausibly exogenous, controlling for additional determining factors of the leverage SOA that may be correlated with the media's news coverage, and using a shock to news media coverage.

\subsection{Different Types of News}

We first run our analysis for three news categories: firm-initiated news, press-initiated news, and non-financial news. ${ }^{12}$ By focusing on the press-initiated news, we can alleviate the concern that news media coverage is endogenous because it may be manipulated by firms and thus correlated with unobserved firm-level characteristics (i.e., omitted-variable bias). ${ }^{13}$ In addition, we focus on non-financial news, defined as news excluding events related to financing activities, such as M\&As (mergers and acquisitions) and debt or equity issuance. Financial news may be related to firms' financial policies, such as capital allocations, capital issues, and distributions, which may be directly or indirectly related to capital structure decisions. By restricting our analysis to nonfinancial news, which is more exogenous to those decisions, we are able to mitigate the endogeneity concern that news coverage and content could be driven by leverage adjustments (i.e., reverse causality).

[Insert Table 4 here]

\footnotetext{
${ }^{12}$ Each news event can be categorized as either firm-initiated or press-initiated news, and either financial or nonfinancial news. Firm-initiated news refers to announcements released by firms and distributed by news providers.

${ }^{13}$ There are scenarios in which press-initiated news becomes less exogenous. For instance, Dyck and Zingales (2003) argue that journalists and firms may maintain a quid pro quo relationship, where they exchange access to firm information for control over how the news stories are presented.
} 
We re-estimate Equation (6) for these types of news and present the regression results in Table 4. The results in Models (3)-(6) show that the coefficients on our main variables of interest, the interaction terms NewsCove $\times D L E V$ and NewsTone $\times D L E V$, are positive and statistically significant, suggesting that these two types of news, press-initiated and non-financial, both have a positive effect on SOA. In sum, our main findings continue to hold when we focus on the subsamples of firms with more exogenous categories of news.

\subsection{Additional Controls}

To further alleviate the potential endogeneity concern due to the presence of time-varying omitted variables, in what follows we control for additional country- and firm-level factors that may be correlated with news media coverage and the leverage SOA. First, we incorporate an interaction between a firm's leverage deviation and cash flow status into our analysis because Faulkender et al. (2012) document that the cost and speed of leverage adjustment depend on whether firms are over- or under-levered relative to target leverage (OVER), as well as whether they have a financing deficit $(D E F)$ or surplus (SURPLUS). We thus add to Equation (6) a triple interaction term capturing a firm's joint status of having above-target leverage and a financing surplus: $O V E R \times S U R P L U S \times D L E V$. In addition, we control for the structure of a country's financial system (FIN_EMPHASIS), a dummy variable equal to one if the financial system's structure is bank-based or market-based, and zero otherwise. We also include the size of the stock market $(M C A P)$. We control for these additional two variables because Öztekin and Flannery (2012) suggest that, if a country's institutional characteristics are more conducive to debt and equity issuances, firms in that country are likely to exhibit higher adjustment speeds.

[Insert Table 5 here] 
We re-estimate Equation (6) using these additional controls and report the results in Panel A of Table 5. In Models (1) and (2) we control for industry-, country-, and year-fixed effects while in Models (3) and (4) we further control for firm- and year-fixed effects. Using firm-fixed effects allows us to account for time-invariant unobservable firm-level variables, which further addresses the omitted variable bias. In Models (1) and (2), over-levered firms with a financing surplus have a higher leverage SOA as the coefficients on $O V E R \times D E F \times S U R P L U S$ are positive and significant. We also find that the coefficients on FIN_EMPHASIS $\times$ DLEV are positive and statistically significant, indicating that firms in countries with a market- or bank-based financial structure are likely to exhibit higher SOAs. Importantly, we find that the coefficients on NewsCove $\times D L E V$ and NewsTone $\times D L E V$ remain positive and statistically significant, suggesting that our results are robust to the inclusion of these additional controls.

In Panel B of Table 5, we incorporate within Equation (3) additional firm-, industry-, and macro-level controls that are the most commonly used determinants of (target) leverage (e.g., Frank and Goyal, 2009; Öztekin and Flannery, 2012; Öztekin, 2015); see the list of those variables in Section 3.1. This test enables us to control for several confounding effects. For instance, if highgrowth and more profitable firms attract more news coverage with a more positive tone, while also making quicker leverage adjustments (e.g., Drobetz and Wanzenried, 2006), then our evidence may reflect a spurious correlation between the media and the SOA. However, the results across all models show that the coefficients on NewsCove $\times D L E V$ and NewsTone $\times D L E V$ are positive and statistically significant, suggesting that our findings are unlikely to be driven by confounding effects. 


\subsection{National Newspaper Strikes}

In a further attempt to address endogeneity, we follow Peress (2014) and use national newspaper strikes as a plausibly exogenous shock to news coverage to assess the causal impact of the media on the leverage SOA. Newspaper strikes, which take the form of journalists' strikes, printers' strikes, or distributors' strikes, result in a decrease in news coverage as they prevent readers from receiving news. This decrease in news coverage is plausibly exogenous to firms' capital structure decisions to a large extent. We therefore expect that firms headquartered in a country that experiences newspaper strikes should exhibit slower leverage adjustment.

To perform the analysis using national newspaper strikes, we collect data on several strikes from Peress (2014) and RavenPack database. The data cover those strikes that (1) affect the press on a national scale and (2) involve the publishing and media sectors only. Over the sample period from 2000 to 2010, there were 33 eligible national newspaper strikes in eight countries, namely, Australia, Canada, France, Greece, Italy, Norway, the U.K., and the U.S. (see Table IA.4 in our internet appendix for more details). We measure national newspaper strikes by either a dummy variable (DUMMY_STRIKE), which equals one if there is a newspaper strike in a country in a given year, and zero otherwise, or a count variable (NUMBER_STRIKE) that captures the number of national newspaper strikes in a country in a given year. We estimate a modified model specification of Equation (6) that incorporates two interaction terms, DUMMY_STRIKE $\times D L E V$ and NUMBER_STRIKE $\times D L E V$. We run our analysis for the whole sample as well as a subsample of firms that do not operate in the media and publishing sectors. By using the latter sample, we can focus on non-media firms, whose financial policies are unlikely to be related to the national newspaper strikes.

[Insert Table 6 here] 
Table 6 presents the regression results. We find that the coefficients on the interaction terms DUMMY_STRIKE $\times D L E V$ and NUMBER_STRIKE $\times D L E V$ are negative and statistically significant, which is in line with our conjecture that an exogenous decrease in news coverage resulting from national newspaper strikes is associated with a lower SOA. Overall, our analysis documents some evidence of a causal, positive effect of news coverage on the leverage SOA. ${ }^{14}$

\section{Possible Channels}

Based on our earlier discussion of the dual role played by the media, we next explore two channels through which the media helps facilitate firms' leverage adjustments, namely information dissemination and corporate governance. It is important to note that these underlying mechanisms are not necessarily mutually exclusive and, if anything, may jointly contribute toward explaining the relationship in question.

\subsection{Information Disseminating Channel}

Based on $\mathbf{H l a}$, we contend that the media plays an important role by disseminating news, thus increasing investor recognition, improving firm visibility, and reducing information asymmetry. Hence, if the positive effect of news coverage and content on the leverage SOA is driven by the media's dissemination of corporate information, then this effect should be weaker (stronger) for firms with lower (greater) information asymmetry. Similarly, this effect should also be weaker (stronger) for firms operating in countries with more (less) transparent information environments.

\footnotetext{
${ }^{14}$ In another attempt to alleviate the endogeneity issue, we perform an instrumental variable regression. We obtain qualitatively similar results. See our internet appendix for more details.
} 
To test this prediction, we modify Equation (6) by adding the interaction term between news, deviation from target leverage, and information asymmetry: $N E W S \times D L E V \times I A$. The coefficients on $N E W S \times D L E V \times I A$ capture the impact of news coverage on the leverage SOA, conditional on the degree of asymmetric information. Our proxies for information asymmetry (IA) are indicator variables, constructed either at the firm or country level. We measure country-level information environments $(I A)$ using three indicators based on the accounting standard score index (ACCST) (La Porta et al., 1998), the disclosure score index (DISC) (Jin and Myers, 2006), or the aggregate measure of country-level asymmetric information for all markets $(A A I)$; the latter measure is a principal component of corporate transparency, equity disclosure, equity liability, equity public enforcement, equity insider trading, and debt information sharing (Öztekin and Flannery, 2012). Following prior studies (Bushman, Piotroski, and Smith, 2004; Jin and Myers, 2006), we also proxy for a firm's information asymmetry (IA) using either an indicator variable based on the number of analysts following the firm ( $A N A)$ or a dummy variable (BIG4) that equals one if the firm is audited by a Big 4 auditor, and zero otherwise. All these indicators are set as one if the corresponding variables are greater than their annual median values, and zero otherwise.

[Insert Table 7 here]

Panel A of Table 7 presents the regression results in which we proxy for $I A$ using countrylevel information environments. The results show that the coefficients on the triple interaction term, NewsCove $\times D L E V \times I A$ or NewsTone $\times D L E V \times I A$, are generally negative and statistically significant, suggesting that the positive effect of news coverage and content on the leverage SOA is weaker for firms operating in countries with more transparent information environments.

In Panel B of Table 7, we present the results from the regressions in which we use proxies for firm-level information environment, $A N A$ and $B I G 4$. We observe that the coefficients on the 
interaction term between the news variables and the deviation from target leverage are qualitatively similar to those in the baseline regression results. To the extent that analysts represent a different channel of information acquisition (e.g., Derrien and Kecskés, 2013), these results suggest that the media still facilitates leverage adjustments even after controlling for this alternative channel. Importantly, the coefficients on the triple interaction term, NewsCove $\times D L E V \times I A$, are negative and significant, indicating that the positive impact of news coverage on the SOA is attenuated for firms with higher analyst coverage or a Big 4 auditor. Since these firms have lower information asymmetry, our results generally support the conjecture that the effect of the news media on the SOA is less pronounced for firms with a lower degree of information asymmetry.

\subsection{Monitoring Channel}

Due to the separation of ownership and control, firms may face a potential moral hazard problem in which managers prefer a quiet life (Bertrand and Mullainathan, 2003) and avoid difficult tasks such as pursuing optimal capital structure policies. However, as predicted by $\mathbf{H 1 a}$, monitoring by the media can reduce agency costs that hinder leverage adjustments, enabling firms to better follow optimal financial policies (Morellec, Nikolov, and Schurhoff, 2012). To the extent that the media helps facilitate dynamic leverage rebalancing via the monitoring channel, the effect of news coverage and content on the SOA should be stronger (weaker) for more weakly governed (better-governed) firms and for firms operating in countries with weaker (stronger) governance effectiveness.

To test this prediction, we modify Equation (6) by adding the triple interaction term between the news media, deviation from target leverage, and governance: $N E W S \times D L E V \times G O V$, where GOV is a dummy variable proxying for either country-level or firm-level governance. To measure country-level governance, we follow La Porta et al. (1998) and use an indicator 
$(C O M L A W)$ that equals one if a country has a common law tradition, and zero otherwise. La Porta et al. (1998) find that countries whose legal systems are based on English common law have the strongest protection of external shareholders. We also follow Kaufmann, Kraay, and Mastruzzi (2011) and use two indicators based on the regulatory quality (RQUAL) and government effectiveness indices (GGOV). To proxy for firm-level governance, we use two dummy variables based on institutional ownership $(I O)$ and institutional block ownership $(B I O)$; higher $I O$ and $B I O$ are associated with better governance because institutional investors are more likely to monitor and discipline managers (Shleifer and Vishny, 1986; Aggarwal et al., 2011). ${ }^{15}$ Our indicators equal one if the corresponding variables are greater than their annual median values, and zero otherwise.

[Insert Table 8 here]

Panel A of Table 8 presents the regression results obtained when we proxy for countrylevel governance (GOV) using COMLAW, RQUAL, or GOVEF. We find that the coefficients on the interaction terms NewsCove $\times D L E V \times G O V$ and NewsTone $\times D L E V \times G O V$ are negative and generally significant, suggesting that the positive impact of news coverage and content on leverage adjustment speeds is weaker in countries with better governance.

Panel B of Table 8 presents the regression results obtained when we proxy for firm-level governance using either $I O$ or $B I O$. We continue to find that news coverage and content are positively related to the leverage SOA, as shown by the positive and significant coefficients on the interaction terms between the news variables and the deviation from target leverage. To the extent that the presence of institutional investors and blockholders represents another mechanism of

\footnotetext{
${ }^{15}$ Institutional blockholders may improve but may also worsen corporate governance depending on their firm ownership stakes (see Edmans (2014) for a survey of the literature on blockholders). For this reason, we use both institutional ownership and institutional block ownership in this test.
} 
information acquisition and governance, these results show that our main findings continue to hold after controlling for this alternative mechanism. Importantly, we find that the coefficients on the triple interaction terms NewsCove $\times D L E V \times I O$ and NewsCove $\times D L E V \times B I O$ are negative and significant in all models. These results indicate that the effect of the media on the SOA is generally less pronounced for firms with higher levels of institutional (block) ownership, i.e., those with better governance. This finding is consistent with the monitoring role of the media. The results for the tone of news are weaker, possibly because, as argued in Section 2, the potential impact of the tone of news on agency conflicts is ambiguous. While more positive news may reflect better governance quality, it may also insulate management from external pressure, thus enhancing their decision-making discretion. In short, the weak results for news tone may be due to the presence of the two potential opposite effects of news sentiment on agency conflicts.

\section{Further Analyses ${ }^{16}$}

\subsection{The Costs and Benefits of Leverage Adjustments}

Our analysis has thus far supported the argument that the media's news coverage and content can reduce leverage adjustment costs, leading to a higher leverage SOA. To provide further evidence in support of this view, in this section we attempt to relate these news variables to the leverage SOA conditional on measures of leverage adjustment costs and benefits. Our analysis is motivated by Öztekin and Flannery (2012), who document that country-level institutional factors capturing adjustment costs and benefits could affect firms' adjustment speeds. Specifically, they argue that if a country's institutional characteristics make it more expensive and less beneficial for

\footnotetext{
${ }^{16}$ We thank the anonymous referees for their helpful comments and suggestions on these analyses.
} 
firms operating in that country to issue debt and equity and undertake capital structure adjustment, then those firms will exhibit slower adjustment speeds. Based on this reasoning, we explore whether the effect of the media's news on the leverage SOA varies with a country's institutional factors characterized by higher adjustment costs or lower adjustment benefits.

We hypothesize that if the media mitigates the adverse effect of a country's institutional environment associated with higher adjustment costs or lower adjustment benefits through its effective role in information disseminating and monitoring, then the effects of news coverage and content on the SOA will be more pronounced when firms operate in such an environment. Alternatively, if the media does not reduce, or even exacerbates, the adverse effect of institutional factors associated with higher adjustment costs or lower adjustment benefits, especially when these factors make it prohibitively costly for firms to adjust their capital structure, then the effects of news coverage and content on the SOA will be insignificant or even become weaker in these environments. ${ }^{17}$ Ultimately, the impact of country-level adjustment costs and benefits on the association between news media coverage and the leverage SOA is an empirical question.

An empirical challenge of this analysis, however, is that there are no uniform (countrylevel) measures of leverage adjustment costs and benefits in the existing literature. We thus follow Öztekin and Flannery (2012) and adopt three most relevant principal component measures based

\footnotetext{
${ }^{17}$ To the extent that leverage adjustment costs are positively associated with target leverage range, that is, the range within which firms do not adjust their capital structure, our arguments imply a nonlinear relation between different determinants of adjustment costs and benefits, including the country-specific factors and firm-level news variables under consideration, and the width of this target range. These predictions are consistent with prior dynamic capital structure models (e.g., Fischer, Heinkel, and Zechner, 1989) that allow for such nonlinearity.
} 
on a country's institutional environment. First, we use an indicator variable based on the ease of access to equity markets (ACCESS_EQUITY) to measure the cost of leverage adjustments. Access to equity markets is calculated as the first principal component of shareholder rights and shareholder right enforcement. ${ }^{18}$ As an indicator, ACCESS_EQUITY implies stronger protection of shareholders' rights, a lower cost of capital, a lower cost of leverage adjustment, and ultimately a higher SOA. ${ }^{19}$

Second, to measure the benefits of leverage adjustments, we use ex ante bankruptcy costs (EA_BCOST), which is a dummy variable based on the first principal component of credit rights and creditor right index. In countries in which lenders can easily force repayment, repossess collateral, gain control of the firm, or enforce debt contracts, the value of quickly reversing leverage increases is likely higher (Öztekin and Flannery, 2012). Hence, higher ex ante distress costs should result in faster leverage adjustments. Additionally, we use an indicator based on deviation penalties $(D E V P)$, which, in turn, is the first principal component of another four indices: the executive quality, the quality of contract enforcement, the strength of law and order, and the quality of government. According to Öztekin and Flannery (2012), rebalancing benefits are greater in countries with more constraints on executive power, better quality of contract enforcement, better legal systems, and stronger governance. As dummy variables, both $E A \_B C O S T$ and $D V E P$

\footnotetext{
${ }^{18}$ In this analysis, we prefer to use principal components as they capture multiple dimensions of adjustment costs and benefits, and thus are more informative than single measures. The results also hold when we use the latter.

${ }^{19}$ We do not consider two related measures, access to debt markets and access to all markets, because they include two components: creditor rights and creditor right enforcement indices, which are highly correlated with a measure of ex ante bankruptcy costs adopted later.
} 
capture higher adjustment benefits, which provide firms with stronger incentives to follow optimal capital structure decisions and result in a higher SOA.

$$
\text { [Insert Table } 9 \text { here] }
$$

To test our prediction, we augment Equation (6) by adding triple interactions between the news variables, deviation from target leverage, and indicator variables proxying for adjustment costs or benefits. The coefficients on these interactions capture the incremental effect of news coverage and content on the leverage SOA, conditional on the costs and benefits of leverage adjustments. The results in Table 9 show that most of the coefficients on $A D J \_C O S T \times D L E V$ and $A D J B E N \times D L E V$ are positive and significant, suggesting that better access to equity and debt markets, higher ex ante bankruptcy costs, and greater deviation penalties either enable or incentivize firms to adjust more quickly to target leverage. Importantly, almost all coefficients on the triple interaction terms are significantly negative, suggesting that the impact of news coverage and content on the SOA becomes stronger when firms operate in an environment with poorer access to capital markets, smaller ex ante bankruptcy costs, or smaller deviation penalties. ${ }^{20}$

Overall, these findings support our hypothesis for the effective role of the media in information disseminating and monitoring: the media mitigates the adverse effect of country-level institutional factors associated with higher adjustment costs or lower adjustment benefits, and thus has a more pronounced effect on the SOA for firms operating in such environments.

\footnotetext{
${ }^{20}$ In another test reported in the internet appendix, we provide evidence that both news coverage and sentiment have a negative effect on the implied cost of capital, which in turn implies lower leverage adjustment costs.
} 


\subsection{News Media Coverage and Leverage Adjustment Activities}

In this section, we explore whether news coverage and content facilitate leverage adjustment activities. Recent studies show that external financing activities, namely debt issuances, debt retirements, equity issuances, and equity repurchases, are relevant for a firm's capital structure rebalancing (Öztekin and Flannery, 2012; Çolak, Gungoraydinoglu, and Öztekin, 2018). ${ }^{21}$ To the extent that the news media lowers leverage adjustment costs, it should enhance firms' ability to access capital markets through these external adjustment mechanisms.

To test this prediction, we follow Çolak, Gungoraydinoglu, and Öztekin (2018) and estimate a series of logit regressions of a security issuance or retirement, on news coverage and tone and the controls (i.e., the variables used in the first-stage regression in Equation (2)). ${ }^{22}$ As in recent research (Öztekin and Flannery, 2012), we define a debt issuance, debt retirement, and equity issuance as a security issuance or retirement of at least $5 \%$ of the book assets. An equity retirement is defined as a stock repurchase of at least $1.25 \%$ of the book assets.

\section{[Insert Table 10 here]}

Panels A and B of Table 10 report the regression results for debt and equity transactions, respectively. We find that news coverage has a significant and positive impact on debt issuances and retirements as well as equity issuances and repurchases, suggesting that firms covered more by the media are more likely to engage in external financing activities. The tone of the news also

\footnotetext{
${ }^{21}$ Focusing on U.S. firms, Hovakimian (2004) finds that debt reductions are the only type of transaction that consistently offset deviations from target leverage. Leary and Roberts (2005) show that debt issuances are more important than equity issuances for rebalancing capital structures.

${ }^{22}$ See also our internet appendix (Table IA.6) for a univariate analysis of the frequency and size of adjustments.
} 
has significantly positive effects on the likelihoods of firms issuing debt and equity. ${ }^{23}$ However, while news sentiment is positively related to debt retirements, it is negatively related to equity repurchases. The latter finding implies that firms with more positive news are more likely to retire debt than equity. ${ }^{24}$

As in the main analysis, a potential concern about our inference is the presence of endogeneity. To mitigate this issue, in Panels C and D of Table 10, we rerun our analysis for nonfinancial news, which is more exogenous to firms' financing activities and hence their security issues and retirements. We find that our main findings remain qualitatively unchanged. Overall, the results indicate that the media's news coverage and content have a positive impact on several external financing activities of firms, which in turn helps facilitate their leverage adjustments. ${ }^{25}$

\subsection{Nonlinear Effect of News Media on the Speed of Leverage Adjustment}

In our final analysis, we explore potential asymmetries and nonlinearities in the impact of news coverage and content on the leverage SOA. First, we examine whether this effect is different for under- versus over-levered firms. Our test is motivated by the strong evidence in the literature

${ }^{23}$ If equity is more sensitive to asymmetric information than debt, it may be affected more by the media's dissemination role. In line with this, the impact of news tone on equity issues is larger in magnitude than that on debt.

${ }^{24}$ Firms with positive news are less likely to be undervalued and may have less incentive to buy back their shares.

${ }^{25}$ In further analysis, we follow the approach in Section 6.3 and use national newspaper strikes as an instrument for news coverage to address potential endogeneity concerns. However, the results are somewhat mixed: the impact of strikes on the leverage SOA is only significant and negative for debt retirements and equity repurchases. Overall, we note that the analysis presented in this section is only a preliminary attempt to understand the association between news media coverage and firms' security choices in the broader context of our study of the leverage SOA. Further research on this important question, especially analysis using cleaner identification strategies, is warranted. 
that deviations from target leverage are among the most important determinants of the SOA, and that adjustment speeds significantly vary for firms with above- and below-target leverage (Byoun, 2008; Faulkender et al., 2012). We then study whether the impact of the media on the leverage SOA differs for firms with high media coverage or positive news versus those with the opposite characteristics. Our test is inspired by evidence in prior studies that the impact of news media coverage on equity return (i.e., the cost of equity capital) can be nonlinear (e.g., Medovikov, 2016).

To perform these tests, we modify Equation (6) by adding triple interactions between the news variables, the deviation from target leverage, and three dummy variables that capture whether firms are over- or under-levered, whether they have high media coverage, and whether they have positive news content. The results, reported in detail in Table IA.8 in our internet appendix, document some evidence of asymmetric and nonlinear effects of the news media on the leverage SOA, conditional on whether firms are over-levered relative to their target leverage, covered by more news, and particularly whether the news articles have a more positive tone.

\section{Conclusion}

We study whether and how the media's news coverage affects firms' leverage adjustments. Since recent research shows evidence of both the bright and dark sides of the news media, the impact of the media on firms' leverage adjustment speeds is an open empirical question. Using a comprehensive sample of global news across 33 countries over the 2000-2010 period, we find that media coverage and content have a positive and significant effect on leverage adjustment speeds. Our finding is robust to alternative measures of leverage, advanced regression methods, and different subsamples of countries. We further address endogeneity concerns by examining different categories of news that are plausibly exogenous; controlling for firm-, industry-, and country-level determinants of leverage adjustments that may be correlated with news coverage and tone; and 
exploiting an exogenous variation in media coverage following national newspaper strikes. Our findings continue to hold in those tests. While it is difficult to completely rule out endogeneity, taken together those tests indicate that our main conclusion is unlikely to be affected by this potential concern.

We also explore two possible underlying mechanisms through which the media's news coverage might affect firms' leverage adjustment: the information disseminating and monitoring channels. Our results suggest that the news media can help increase leverage adjustment speeds by reducing the costs of adjustment stemming from information asymmetry or agency conflicts. Overall, our study highlights the important role played by the news media in shaping firms' optimal capital structure decisions. Our evidence supports a positive, rather than a skeptical, view of media coverage and thus contributes to an important and timely debate on the pros and cons of the news media in the economy and wider society. 


\section{References}

Aggarwal, R., Erel, I., Ferreira, M., Matos, P., 2011. Does Governance Travel around the World? Evidence from Institutional Investors. Journal of Financial Economics 100, 154-181.

Ahern, K.R., Sosyura, D., 2014. Who Writes the News? Corporate Press Releases during Merger Negotiations. The Journal of Finance 69, 241-291.

Ahern, K.R., Sosyura, D., 2015. Rumor Has It: Sensationalism in Financial Media. Review of Financial Studies 28, 2050-2093.

An, Z., Li, D., Yu, J., 2015. Firm Crash Risk, Information Environment, and Speed of Leverage Adjustment. Journal of Corporate Finance 31, 132-151.

Antoniou, A., Guney, Y., Paudyal, K., 2008. The Determinants of Capital Structure: Capital Market-Oriented versus Bank-Oriented Institutions. Journal of Financial and Quantitative Analysis 43, 59-92.

Baker, M., Wurgler, J., 2002. Market Timing and Capital Structure. The Journal of Finance 57, 132.

Baltagi, B., 2013. Econometric Analysis of Panel Data, 5 ed. Wiley.

Barber, B., Odean, T., 2008. All that Glitters: The Effect of Attention and News on the Buying Behavior of Individual and Institutional Investors. Review of Financial Studies 21, 785818.

Bednar, M.K., 2012. Watchdog or Lapdog? A Behavioral View of the Media as a Corporate Governance Mechanism. Academy of Management Journal 55, 131-150.

Bertrand, M., Mullainathan, S., 2003. Enjoying the Quiet Life? Corporate Governance and Managerial Preferences. Journal of Political Economy 111, 1043-1075. 
Blankespoor, E., DeHaan, E., 2015. CEO Visibility: Are Media Stars Born or Made. Working Paper, Stanford University.

Blankespoor, E., Miller, G.S., White, H.D., 2014. The Role of Dissemination in Market Liquidity: Evidence from Firms' Use of Twitter. Accounting Review 89, 79-112.

Blundell, R., Bond, S., 1998. Initial Conditions and Moment Restrictions in Dynamic Panel Data Models. Journal of Econometrics 87, 115-143.

Brisker, E.R., Wang, W., 2017. CEO's Inside Debt and Dynamics of Capital Structure. Financial Management 46, 655-685.

Bushee, B.J., Core, J.E., Guay, W., Hamm, S.J.W., 2010. The Role of the Business Press as an Information Intermediary. Journal of Accounting Research 48, 1-19.

Bushman, R.M., Piotroski, J.D., Smith, A.J., 2004. What Determines Corporate Transparency? Journal of Accounting Research 42, 207-252.

Bushman, R.M., Williams, C.D., Wittenberg-Moerman, R., 2017. The Informational Role of the Media in Private Lending. Journal of Accounting Research 55, 115-152.

Byoun, S., 2008. How and When Do Firms Adjust Their Capital Structures toward Targets? The Journal of Finance 63, 3069-3096.

Chang, Y.K., Chou, R.K., Huang, T.H., 2014. Corporate Governance and the Dynamics of Capital Structure: New Evidence. Journal of Banking and Finance 48, 374-385.

Chang, X., Dasgupta, S., 2009. Target Behavior and Financing: How Conclusive Is the Evidence? The Journal of Finance 64, 1767-1796.

Clarke, J., Chen, H., Du, D., Hu, Y., 2018. Fake News, Investor Attention, and Market Reaction. Working Paper, Georgia Institute of Technology, City University of Hong Kong, and Carnegie Mellon University. 
Çolak, G., Gungoraydinoglu, A., Öztekin, Ö., 2018. Global Leverage Adjustments, Uncertainty, and Country Institutional Strength. Journal of Financial Intermediation 35, 41-56.

Cook, D.O., Tang, T., 2010. Macroeconomic Conditions and Capital Structure Adjustment Speed. Journal of Corporate Finance 16, 73-87.

Core, J.E., Guay, W., Larcker, D.F., 2008. The Power of the Pen and Executive Compensation. Journal of Financial Economics 88, 1-25.

Dai, L., Parwada, J.T., Zhang, B., 2015. The Governance Effect of the Media's News Dissemination Role: Evidence from Insider Trading. Journal of Accounting Research 53, $331-366$.

Dai, L., Shen, R., Zhang, B., 2018. Does the Media Spotlight Burn or Spur Innovation? Working Paper, University of New South Wales, Nanyang Technological University, and Chinese University of Hong Kong.

Dang, T.L., Moshirian, F., Zhang, B., 2015. Commonality in News around the World. Journal of Financial Economics 116, 82-110.

Dang, V.A., Kim, M., Shin, Y., 2012. Asymmetric Capital Structure Adjustments: New Evidence from Dynamic Panel Threshold Models. Journal of Empirical Finance 19, 465-482.

Dang, V.A., Kim, M., Shin, Y., 2015. In Search of Robust Methods for Dynamic Panel Data Models in Empirical Corporate Finance. Journal of Banking and Finance 53, 84-98.

DeAngelo, H., DeAngelo, L., Whited, T.M., 2011. Capital Structure Dynamics and Transitory Debt. Journal of Financial Economics 99, 235-261.

DeHaan, E., Shevlin, T., Thornock, J., 2015. Market (In)Attention and the Strategic Scheduling and Timing of Earnings Announcements. Journal of Accounting and Economics 60, 36-55.

Derrien, F., Kecskés, A., 2013. The Real Effects of Financial Shocks: Evidence from Exogenous 
Changes in Analyst Coverage. The Journal of Finance 68, 1407-1440.

Devos, E., Rahman, S., Tsang, D., 2017. Debt Covenants and the Speed of Capital Structure Adjustment. Journal of Corporate Finance 45, 1-18.

Drake, M.S., Guest, N.M., Twedt, B.J., 2014. The Media and Mispricing: The Role of the Business Press in the Pricing of Accounting Information. Accounting Review 89, 1673-1701.

Drobetz, W., Wanzenried, G., 2006. What Determines the Speed of Adjustment to the Target Capital Structure? Applied Financial Economics 16, 941-958.

Dyck, A., Morse, A., Zingales, L., 2010. Who Blows the Whistle on Corporate Fraud? The Journal of Finance 65, 2213-2253.

Dyck, A., Volchkova, N., Zingales, L., 2008. The Corporate Governance Role of the Media: Evidence from Russia. The Journal of Finance 63, 1093-1135.

Dyck, A., Zingales, L., 2002. The Corporate Governance Role of the Media. Working paper, Harvard University.

Dyck, A., Zingales, L., 2003. The Media and Asset Prices. Working paper, Harvard University.

Edmans, A., 2014. Blockholders and Corporate Governance. Annual Review of Financial Economics 6, 23-50.

Elsas, R., Flannery, M.J., Garfinkel, J.A., 2014. Financing Major Investments: Information about Capital Structure Decisions. Review of Finance 18, 1341-1386.

Elsas, R., Florysiak, D., 2011. Heterogeneity in the Speed of Adjustment toward Target Leverage. International Review of Finance 11, 181-211.

Elsas, R., Florysiak, D., 2015. Dynamic Capital Structure Adjustment and the Impact of Fractional Dependent Variables. Journal of Financial and Quantitative Analysis 50, 1105-1133.

Fama, E.F., French, K.R., 2002. Testing Trade-Off and Pecking Order Predictions about Dividends 
and Debt. Review of Financial Studies 15, 1-33.

Fang, L., Peress, J., 2009. Media Coverage and the Cross-section of Stock Returns. The Journal of Finance 64, 2023-2052.

Faulkender, M., Flannery, M.J., Hankins, K.W., Smith, J.M., 2012. Cash Flows and Leverage Adjustments. Journal of Financial Economics 103, 632-646.

Fier, S.G., McCullough, K.A., Carson, J.M., 2013. Internal Capital Markets and the Partial Adjustment of Leverage. Journal of Banking and Finance 37, 1029-1039.

Fischer, E.O., Heinkel, R., Zechner, J., 1989. Dynamic Capital Structure Choice: Theory and Tests. The Journal of Finance 44, 19-40.

Flannery, M.J., Hankins, K.W., 2013. Estimating Dynamic Panel Models in Corporate Finance. Journal of Corporate Finance 19, 1-19.

Flannery, M.J., Rangan, K.P., 2006. Partial Adjustment toward Target Capital Structures. Journal of Financial Economics 79, 469-506.

Frank, M.Z., Goyal, V.K., 2008. Chapter 12 - Trade-Off and Pecking Order Theories of Debt in Eckbo, B. (Ed.), Handbook of Empirical Corporate Finance. Elsevier, San Diego, pp. 135202.

Frank, M.Z., Goyal, V.K., 2009. Capital Structure Decisions: Which Factors Are Reliably Important? Financial Management 38, 1-37.

Frankel, R., Li, X., 2004. Characteristics of a Firm's Information Environment and the Information Asymmetry between Insiders and Outsiders. Journal of Accounting and Economics 37, $229-259$.

Goldstein, R., Ju, N., Leland, H., 2001. An EBIT-Based Model of Dynamic Capital Structure. Journal of Business 74, 483-512. 
Graham, J.R., Leary, M.T., 2011. A Review of Empirical Capital Structure Research and Directions for the Future. Annual Review of Financial Economics 3, 309-345.

Green, J., Hand, J., Penn, M., 2014. Business Press Coverage and the Market Pricing of Good and Bad News, Working Paper, Pennsylvania State University, University of North Carolina at Chapel Hill, and Florida State University.

Gurun, U.G., Butler, A.W., 2012. Don't Believe the Hype: Local Media Slant, Local Advertising, and Firm Value. The Journal of Finance 67, 561-598.

Halling, M., Yu, J., Zechner, J., 2016. Leverage Dynamics over the Business Cycle. Journal of Financial Economics 122, 21-41.

Hayward, M.L., Rindova, V. P., Pollock, T. G., 2004. Believing One's Own Press: The Causes and Consequences of CEO celebrity. Strategic Management Journal 25, 637-653.

Hennessy, C.A., Whited, T.M., 2007. How Costly Is External Financing? Evidence from a Structural Estimation. The Journal of Finance 62, 1705-1745.

Hovakimian, A., 2004. The Role of Target Leverage in Security Issues and Repurchases. The Journal of Business 77, 1041-1072.

Hovakimian, A., Opler, T., Titman, S., 2001. The Debt-Equity Choice: An Analysis of Issuing Firms. Journal of Financial and Quantitative Analysis 36, 1-24.

Huang, R., Ritter, J.R., 2009. Testing Theories of Capital Structure and Estimating the Speed of Adjustment. Journal of Financial and Quantitative Analysis 44, 237-271.

Jensen, M., 1979. Toward a Theory of the Press, in K. Brunner (ed.), Economics Social Institutions Springer Netherlands, 267-287.

Jiang, F., Jiang, Z., Huang, J., Kim, K.A., Nofsinger, J.R., 2017. Bank Competition and Leverage Adjustments. Financial Management 46, 995-1022. 
Jin, L., Myers, S.C., 2006. R2 around the World: New Theory and New Tests. Journal of Financial Economics 79, 257-292.

Joe, J.R., Louis, H., Robinson, D., 2009. Managers' and Investors' Responses to Media Exposure of Board Ineffectiveness. Journal of Financial and Quantitative Analysis 44, 579-605.

Judson, R.A., Owen, A.L., 1999. Estimating Dynamic Panel Data Models: A Guide for Macroeconomists. Economics Letters 65, 9-15.

Kaufmann, D., Kraay, A., Mastruzzi, M., 2011. The Worldwide Governance Indicators: Methodology and Analytical Issues. Hague Journal on the Rule of Law 3, 220-246.

Korajczyk, R.A., Lucas, D.J., McDonald, R.L., 1991. The Effect of Information Releases on the Pricing and Timing of Equity Issues. Review of Financial Studies 4, 685-708.

Kothari, S.P., Xu, L., Short, J.E., 2009. The Effect of Disclosures by Management, Analysts, and Business Press on Cost of Capital, Return Volatility, and Analyst Forecasts: A Study Using Content Analysis. Accounting Review 84, 1639-1670.

Kuhnen, C.M., Niessen, A., 2012. Public Opinion and Executive Compensation. Management Science 58, 1249-1272.

Lai, S., Ng, L., Zhang, B., 2014. Does PIN Affect Equity Prices around the World. Journal of Financial Economics 114, 178-195.

Leary, M.T., Roberts, M.R., 2005. Do Firms Rebalance Their Capital Structures? The Journal of Finance 60, 2575-2619.

Lemmon, M.L., Roberts, M.R., Zender, J.F., 2008. Back to the Beginning: Persistence and the Cross-Section of Corporate Capital Structure. The Journal of Finance 63, 1575-1608.

Levine, R., 2002. Bank-Based or Market-Based Financial Systems: Which Is Better? Journal of Financial Intermediation 11, 398-428. 
Liao, L.K., Mukherjee, T., Wang, W., 2015. Corporate Governance and Capital Structure Dynamics An Empirical Study. Journal of Financial Research 38, 169-192.

Liu, B., McConnell, J.J., 2013. The Role of the Media in Corporate Governance: Do the Media Influence Managers' Capital Allocation Decisions? Journal of Financial Economics 110, $1-17$.

Lockhart, G.B., 2014. Credit Lines and Leverage Adjustments. Journal of Corporate Finance 25, $274-288$.

Loudermilk, M.S., 2007. Estimation of Fractional Dependent Variables in Dynamic Panel Data Models with an Application to Firm Dividend Policy. Journal of Business and Economic Statistics 25, 462-472.

Medovikov, I., 2016. When Does the Stock Market Listen to Economic News? New Evidence from Copulas and News Wires. Journal of Banking and Finance 65, 27-40.

Miller, G.S., 2006. The Press as a Watchdog for Accounting Fraud. Journal of Accounting Research 44, 1001-1033.

Miller, G.S., Skinner, D.J., 2015. The Evolving Disclosure Landscape: How Changes in Technology, the Media, and Capital Markets Are Affecting Disclosure. Journal of Accounting Research 53, 221-239.

Modigliani, F., Miller, M.H., 1958. The Cost of Capital, Corporation Finance and the Theory of Investment. American Economic Review 48, 261.

Morck, R., Yeung, B., Yu, W., 2000. The Information Content of Stock Markets: Why Do Emerging Markets Have Synchronous Stock Price Movements? Journal of Financial Economics 58, $215-260$.

Morellec, E., Nikolov, B., Schurhoff, N., 2012. Corporate Governance and Capital Structure 
Dynamics. The Journal of Finance 67, 803-848.

Myers, S.C., 1984. The Capital Structure Puzzle. The Journal of Finance 39, 574-592.

Myers, S.C., Majluf, N.S., 1984. Corporate Financing and Investment Decisions When Firms Have Information That Investors Do Not Have. Journal of Financial Economics 13, 187-221.

Öztekin, Ö., 2015. Capital Structure Decisions around the World: Which Factors Are Reliably Important? Journal of Financial and Quantitative Analysis 50, 301-323.

Öztekin, Ö., Flannery, M.J., 2012. Institutional Determinants of Capital Structure Adjustment Speeds. Journal of Financial Economics 103, 88-112.

Pagan, A., 1984. Econometric Issues in the Analysis of Regressions with Generated Regressors. International Economic Review 25, 221-247.

Parsons, C., Titman, S., 2009. Empirical Capital Structure: A Review. Foundations and Trends in Finance 3, 1-93.

Peress, J., 2014. The Media and the Diffusion of Information in Financial Markets: Evidence from Newspaper Strikes. The Journal of Finance 69, 2007-2043.

Porta, R.L., Lopez-de-Silanes, F., Shleifer, A., Vishny, R., 1998. Law and Finance. Journal of Political Economy 106, 1113-1155.

Roodman, D., 2009. How to Do xtabond2: An Introduction to Difference and System GMM in Stata. Stata Journal 9, 86-136.

Shleifer, A., Vishny, R.W., 1986. Large Shareholders and Corporate Control. Journal of Political Economy 94, 461-488.

Solomon, D.H., 2012. Selective Publicity and Stock Prices. The Journal of Finance 67, 599-638.

Solomon, D.H., Soltes, E.F., 2012. Managerial Control of Business Press Coverage, Working Paper, University of Southern California and Harvard Business School. 
Solomon, D.H., Soltes, E., Sosyura, D., 2014. Winners in the Spotlight: Media Coverage of Fund Holdings as a Driver of Flows. Journal of Financial Economics 113, 53-72.

Strebulaev, I.A., 2007. Do Tests of Capital Structure Theory Mean What They Say? The Journal of Finance 62, 1747-1787.

Tetlock, P.C., 2010. Does Public Financial News Resolve Asymmetric Information? Review of Financial Studies 23, 3520-3557.

Tetlock, P.C., Saar-Tsechansky, M., Macskassy, S., 2008. More Than Words: Quantifying Language to Measure Firms' Fundamentals. The Journal of Finance 63, 1437-1467.

Turner, J.D., Ye, Q., Walker, C.B., 2018. Media Coverage and Stock Returns on the London Stock Exchange, 1825-70. Review of Finance 4, 1605-1629.

Warr, R.S., Elliott, W.B., Koëter-Kant, J., Öztekin, Ö., 2012. Equity Mispricing and Leverage Adjustment Costs. Journal of Financial and Quantitative Analysis 47, 589-616.

Welch, I., 2004. Capital Structure and Stock Returns. Journal of Political Economy 112, 106-131. Wooldridge, J.M., 2005. Fixed-Effects and Related Estimators for Correlated Random-Coefficient and Treatment-Effect Panel Data Models. The Review of Economics and Statistics 87, $385-390$.

Zhou, Q., Tan, K.J.K., Faff, R., Zhu, Y., 2016. Deviation from Target Capital Structure, Cost of Equity and Speed of Adjustment. Journal of Corporate Finance 39, 99-120. 


\section{Appendix A: Variable Definitions}

\begin{tabular}{|c|c|c|c|}
\hline Variables & Acronym & Description & Data sources \\
\hline \multicolumn{4}{|c|}{ A. Firm-level variables } \\
\hline \multicolumn{4}{|l|}{ A.1. Leverage } \\
\hline Book leverage & $B L E V$ & Book value of total debt divided by the book value of total assets. & Worldscope \\
\hline Market leverage & $M L E V$ & $\begin{array}{l}\text { Book value of total debt divided by the sum of market value of } \\
\text { equity and the book value of total debt. }\end{array}$ & Worldscope \\
\hline \multicolumn{4}{|c|}{ A.2. Media news variables } \\
\hline News coverage & NewsCove & $\begin{array}{l}\text { The extent of news coverage, which is the log of one plus the } \\
\text { number of news reports about a firm in each year. }\end{array}$ & RavenPack \\
\hline News tone & NewsTone & $\begin{array}{l}\text { The tone of the news, which is the average ESS score for a firm in } \\
\text { each year. ESS scores are scaled so their values range between -1 } \\
\text { and } 1 \text { with negative, positive, and zero values indicating negative, } \\
\text { positive, and neutral tones for the news, respectively. }\end{array}$ & RavenPack \\
\hline Firm-specific news & NewsFirm & $\begin{array}{l}\text { The extent of firm-specific news coverage, which is the logistic } \\
\text { transformation of } \mathrm{R}^{2}\left(\log \left(1-R^{2} / R^{2}\right)\right) \text { estimated from a firm's weekly } \\
\text { news-sentiment scores regressed on a country's weekly news- } \\
\text { sentiment scores. }\end{array}$ & RavenPack \\
\hline
\end{tabular}

\section{A.3. Other firm-level characteristics}

\begin{tabular}{|c|c|c|c|}
\hline $\begin{array}{l}\text { Above-target } \\
\text { leverage }\end{array}$ & OVER & $\begin{array}{l}\text { A dummy that equals one if the firm is over-levered relative to target } \\
\text { leverage, and zero otherwise. }\end{array}$ & Worldscope \\
\hline $\begin{array}{l}\text { Financing deficit/ } \\
\text { surplus }\end{array}$ & $\begin{array}{l}\text { DEF/ } \\
\text { SURPLUS }\end{array}$ & $\begin{array}{l}\text { A dummy that equals one if the firm has a financing deficit } \\
\text { (surplus), and zero otherwise. }\end{array}$ & Worldscope \\
\hline Tangibility & $T A N G$ & Net property, plant and equipment scaled by total assets. & Worldscope \\
\hline Firm size & SIZE & Log of the book value of total assets denominated in U.S. dollars. & Worldscope \\
\hline $\begin{array}{l}\text { Market-to-book } \\
\text { ratio }\end{array}$ & $M B$ & Log of market-to-book equity ratio. & Worldscope \\
\hline $\begin{array}{l}\text { Return-on-assets } \\
\text { ratio }\end{array}$ & $R O A$ & Net income before extraordinary items scaled by total assets. & Worldscope \\
\hline $\begin{array}{l}\text { Research and } \\
\text { development }\end{array}$ & $R \& D$ & Research and development expenses scaled by total assets. & Worldscope \\
\hline $\begin{array}{l}\text { Research and } \\
\text { development } \\
\text { dummy }\end{array}$ & $R \& D D$ & $\begin{array}{l}\text { A dummy equal to one if research and development expenses are not } \\
\text { reported, and zero otherwise. }\end{array}$ & Worldscope \\
\hline Depreciation & $D E P$ & Depreciation and amortization divided by total assets. & Worldscope \\
\hline Analyst coverage & $A N A$ & $\begin{array}{l}\text { An indicator equal to one if the number of financial analysts } \\
\text { covering a firm is greater than its annual median, and zero } \\
\text { otherwise. }\end{array}$ & $\mathrm{I} / \mathrm{B} / \mathrm{E} / \mathrm{S}$ \\
\hline $\begin{array}{l}\text { Industry median of } \\
\text { leverage }\end{array}$ & INLEV & $\begin{array}{l}\text { The median of the market leverage (book leverage) of the industry } \\
\text { to which the firm belongs. }\end{array}$ & Worldscope \\
\hline Taxes & $T A X$ & Current income taxes divided by income before income taxes. & Worldscope \\
\hline Liquidity & LIQUID & Total current assets divided by total assets. & Worldscope \\
\hline Global market beta & BETA & $\begin{array}{l}\text { Covariance of the stock return with the global market index return } \\
\text { over the past five years divided by the global market index return } \\
\text { variance. }\end{array}$ & Datastream \\
\hline Forecast errors & ANAERROR & $\begin{array}{l}\text { Absolute value of the difference between the announced earnings } \\
\text { and mean of estimated earnings scaled by the mean of analyst } \\
\text { forecasts }\end{array}$ & $\mathrm{I} / \mathrm{B} / \mathrm{E} / \mathrm{S}$ \\
\hline $\begin{array}{l}\text { Stock return } \\
\text { volatility }\end{array}$ & $S T D$ & Annualized standard deviation of monthly stock returns & Worldscope \\
\hline Big 4 auditor & BIG4 & $\begin{array}{l}\text { A dummy equal to one if the firm is audited by any of the Big } 4 \text { or } \\
\text { Big } 5 \text { auditors, and zero otherwise. }\end{array}$ & $\begin{array}{l}\text { Compustat Global } \\
\& \text { Worldscope }\end{array}$ \\
\hline
\end{tabular}




\begin{tabular}{|c|c|c|c|}
\hline $\begin{array}{l}\text { Institutional } \\
\text { ownership }\end{array}$ & $I O$ & $\begin{array}{l}\text { An indicator equal to one if total institutional ownership, calculated } \\
\text { as the percentage of shares outstanding, is greater than its annual } \\
\text { median, and zero otherwise. }\end{array}$ & $\begin{array}{l}\text { FactSet/Lion- } \\
\text { shares }\end{array}$ \\
\hline $\begin{array}{l}\text { Institutional block } \\
\text { ownership }\end{array}$ & $B I O$ & $\begin{array}{l}\text { An indicator equal to one if institutional block ownership, calculated } \\
\text { as the percentage of block shares outstanding (in which a block } \\
\text { refers to holdings of above } 5 \% \text { of total shares) is greater than its } \\
\text { annual median, and zero otherwise. }\end{array}$ & $\begin{array}{l}\text { FactSet/Lion- } \\
\text { shares }\end{array}$ \\
\hline $\begin{array}{l}\text { High media } \\
\text { coverage }\end{array}$ & HIGHCOV & $\begin{array}{l}\text { A dummy that equals one if the firm has news coverage in excess of } \\
\text { the median value of all sample firms in each country in a given year. }\end{array}$ & RavenPack \\
\hline Positive tone & POSITIVE & $\begin{array}{l}\text { A dummy variable that equals one if the news tone for the firm is } \\
\text { positive, and zero otherwise. }\end{array}$ & RavenPack \\
\hline
\end{tabular}

\begin{tabular}{|c|c|c|c|}
\hline \multicolumn{4}{|c|}{ B. Country-level variables } \\
\hline $\begin{array}{l}\text { Annual inflation } \\
\text { rate }\end{array}$ & $I N F L$ & Growth in consumer price index. & $\begin{array}{l}\text { World } \\
\text { Development } \\
\text { Indicators }\end{array}$ \\
\hline Dividend yields & $D Y$ & $\begin{array}{l}\text { Measured by the total amount of dividends of a country divided by } \\
\text { the total stock market capitalization. }\end{array}$ & Worldscope \\
\hline GDP growth & $G G D P$ & Annual GDP growth. & $\begin{array}{l}\text { World } \\
\text { Development } \\
\text { Indicators }\end{array}$ \\
\hline $\begin{array}{l}\text { Stock market cap } \\
\text { to GDP }\end{array}$ & $M C A P$ & Ratio of stock market capitalization to GDP & $\begin{array}{l}\text { World } \\
\text { Development } \\
\text { Indicators }\end{array}$ \\
\hline Financial emphasis & $\begin{array}{l}\text { FIN_EMPHAS } \\
\text { IS }\end{array}$ & $\begin{array}{l}\text { A dummy that equals one if the financial system structure is bank- } \\
\text { based or market-based, and zero otherwise. }\end{array}$ & Levine (2002) \\
\hline $\begin{array}{l}\text { Accounting } \\
\text { standard }\end{array}$ & $A C C S T$ & $\begin{array}{l}\text { An indicator equal to one if the accounting standard index, which } \\
\text { was created by examining and rating companies' } 1990 \text { annual } \\
\text { reports for their inclusion or omission of } 90 \text { specific accounting } \\
\text { items, covering general information, income statements, balance } \\
\text { sheets, funds flow statement, accounting standards, stock data, and } \\
\text { special items, is greater than its annual median, and zero otherwise. }\end{array}$ & $\begin{array}{l}\text { La Porta et al. } \\
(1998)\end{array}$ \\
\hline Disclosure score & DISC & $\begin{array}{l}\text { An indicator based on a measure of the level of financial disclosure } \\
\text { and availability of information to investors; the latter is calculated } \\
\text { based on survey results about the level and effectiveness of financial } \\
\text { disclosure in the annual Global Competitiveness Report for } 1999 \\
\text { and } 2000 \text {. The indicator is equal to one if the corresponding variable } \\
\text { is greater than its annual median, and zero otherwise. }\end{array}$ & $\begin{array}{l}\text { Jin and Myers } \\
(2006)\end{array}$ \\
\hline $\begin{array}{l}\text { Aggregate } \\
\text { asymmetric } \\
\text { information }\end{array}$ & $A A I$ & $\begin{array}{l}\text { An indicator equal to one if the first principal component (factor } \\
\text { loadings in parentheses) of corporate transparency }(0.80) \text {, equity } \\
\text { disclosure }(0.87) \text {, equity liability }(0.80) \text {, equity public enforcement } \\
(0.75) \text {, and equity insider trading indices }(0.62) \text { is greater than its } \\
\text { annual median, and zero otherwise. }\end{array}$ & $\begin{array}{l}\text { Öztekin and } \\
\text { Flannery (2012) }\end{array}$ \\
\hline Legal origin & COMLAW & $\begin{array}{l}\text { A dummy that takes the value of one if a firm is of common law } \\
\text { origin, and zero otherwise. }\end{array}$ & $\begin{array}{l}\text { La Porta et al. } \\
\text { (1998) }\end{array}$ \\
\hline Regulatory quality & RQUALITY & $\begin{array}{l}\text { An indicator equal to one if the regulatory quality index, which } \\
\text { captures investors' perceptions of the government's ability to } \\
\text { formulate and implement sound policies and regulations that permit } \\
\text { and promote private sector development, is greater than its annual } \\
\text { median, and zero otherwise. }\end{array}$ & $\begin{array}{l}\text { Kaufmann, } \\
\text { Kraay, and } \\
\text { Mastruzzi (2011) }\end{array}$ \\
\hline Good government & $G G O V$ & $\begin{array}{l}\text { An indicator based on how well a country protects private property } \\
\text { rights, which is the sum of three indexes: (i) government corruption, } \\
\text { (ii) the risk of expropriation of private property by the government, } \\
\text { and (iii) the risk of the government repudiating contracts. The }\end{array}$ & $\begin{array}{l}\text { Morck, Yeung, } \\
\text { and Yu (2000) }\end{array}$ \\
\hline
\end{tabular}


indicator is equal to one if the good government index is greater than its annual median, and zero otherwise.

Ease of access to ACCESS_EQU An indicator equal to one if the first principal component (factor Öztekin and equity markets ITY loadings in parentheses) of shareholder rights (0.89) and shareholder Flannery (2012) right enforcement $(0.89)$ is greater than its annual median, and zero otherwise.

Ex ante bankruptcy EA_BCOST An indicator equal to one if the first principal component (factor costs loadings in parentheses) of the creditor rights (0.74) and creditor right indices $(-0.74)$ is greater than its annual median, and zero otherwise.

Deviation penalties DEVP

An indicator equal to one if the first principal component (factor

Öztekin and

Flannery (2012) loadings in parentheses) of executive quality $(0.78)$, contract

Öztekin and enforcement (0.92), law and order (0.84), corruption (0.89), expropriation (0.95), and repudiation (0.90) is greater than its annual median, and zero otherwise. 


\section{Table 1: Summary Statistics}

This table reports the means of firm-level variables by country and for the entire sample. The sample period is 2000-2010. The variable definitions are in Appendix A.

\begin{tabular}{|c|c|c|c|c|c|c|c|c|c|c|c|c|c|c|c|c|}
\hline Country & $B L E V$ & $M L E V$ & NewsCove & NewsTone & NewsFirm & $R O A$ & SIZE & TANG & $M B$ & LIQUID & $D E P$ & $R \& D$ & $R \& D D$ & $T A X$ & $G G D P$ & $I N F L$ \\
\hline Australia & 0.230 & 0.164 & 2.569 & 0.129 & 4.632 & 0.074 & 13.060 & 0.331 & 0.815 & 0.393 & 0.048 & 0.006 & 0.776 & 0.130 & 0.033 & 0.031 \\
\hline Austria & 0.267 & 0.228 & 2.674 & 0.173 & 3.326 & 0.045 & 13.780 & 0.371 & 0.499 & 0.478 & 0.057 & 0.010 & 0.376 & 0.208 & 0.023 & 0.020 \\
\hline Belgium & 0.256 & 0.204 & 2.559 & 0.138 & 3.654 & 0.063 & 13.400 & 0.317 & 0.686 & 0.472 & 0.062 & 0.020 & 0.611 & 0.118 & 0.020 & 0.022 \\
\hline Canada & 0.183 & 0.147 & 3.352 & 0.130 & 4.502 & 0.015 & 12.550 & 0.412 & 0.599 & 0.431 & 0.054 & 0.026 & 0.721 & 0.083 & 0.023 & 0.021 \\
\hline China & 0.249 & 0.211 & 2.428 & 0.198 & 3.735 & 0.070 & 14.530 & 0.495 & 0.478 & 0.404 & 0.044 & 0.002 & 0.692 & 0.116 & 0.098 & 0.019 \\
\hline Denmark & 0.247 & 0.161 & 2.697 & 0.142 & 3.723 & 0.085 & 13.860 & 0.313 & 0.981 & 0.495 & 0.051 & 0.046 & 0.339 & 0.167 & 0.014 & 0.020 \\
\hline Ireland & 0.263 & 0.193 & 2.608 & 0.129 & 3.617 & 0.064 & 13.420 & 0.280 & 0.802 & 0.507 & 0.040 & 0.011 & 0.699 & 0.189 & 0.044 & 0.033 \\
\hline Finland & 0.238 & 0.192 & 2.579 & 0.117 & 3.942 & 0.066 & 13.690 & 0.303 & 0.651 & 0.509 & 0.052 & 0.028 & 0.235 & 0.116 & 0.029 & 0.015 \\
\hline France & 0.247 & 0.196 & 2.847 & 0.139 & 4.498 & 0.043 & 14.630 & 0.200 & 0.718 & 0.500 & 0.046 & 0.024 & 0.529 & 0.251 & 0.017 & 0.017 \\
\hline Germany & 0.195 & 0.160 & 2.362 & & 4.619 & 0.018 & 13.390 & 0.216 & 0.622 & & & 0.032 & 0.394 & 0.207 & 0.013 & 0.016 \\
\hline Greece & 0.303 & 0.225 & & & & & & & & & & & & 0.301 & & 0.032 \\
\hline Hong Kong & 0.176 & 0.173 & & & & 0.052 & & & & & & & & 0.117 & 0.051 & 0.004 \\
\hline Indonesia & 0.320 & 0.270 & 2.203 & & & 0.114 & 13.720 & 0.477 & 0.603 & & & 0.001 & & 0.144 & 0.054 & 0.083 \\
\hline India & 0.281 & 0.240 & 2.450 & 0.229 & 3.019 & 0.100 & 12.340 & 0.376 & 0.567 & 0.523 & 0.034 & 0.004 & 0.600 & 0.308 & 0.076 & 0.069 \\
\hline Italy & 0.287 & 0.225 & 2.373 & 0.124 & 4.228 & 0.033 & 14.300 & 0.234 & 0.720 & 0.487 & 0.052 & 0.006 & 0.754 & 0.200 & 0.011 & 0.023 \\
\hline Japan & 0.207 & 0.193 & 2.245 & 0.059 & 3.848 & 0.028 & 13.830 & 0.305 & 0.223 & 0.535 & 0.035 & 0.018 & 0.243 & 0.222 & 0.012 & -0.001 \\
\hline South Korea & 0.267 & 0.267 & 1.962 & 0.207 & 3.909 & 0.061 & 14.340 & 0.389 & 0.039 & 0.447 & 0.042 & 0.007 & 0.274 & 0.157 & 0.042 & 0.032 \\
\hline Mexico & 0.259 & 0.203 & 2.470 & 0.088 & 3.547 & 0.081 & 15.070 & 0.409 & 0.558 & 0.413 & 0.046 & 0.000 & 1.000 & 0.071 & 0.029 & 0.050 \\
\hline Malaysia & 0.225 & 0.195 & 2.412 & & & 0.077 & 13.390 & 0.398 & & & & & & 0.091 & 0.054 & 0.022 \\
\hline Netherlands & 0.268 & 0.198 & 2.946 & & & 0.059 & 14.580 & 0.245 & 0.806 & & 0.048 & 0.020 & 0.588 & 0.184 & 0.022 & 0.021 \\
\hline Norway & 0.318 & 0.255 & 2.570 & 0.187 & & 0.053 & & 0.378 & 0.635 & & & 0.009 & 0.612 & 0.116 & 0.025 & 0.019 \\
\hline Poland & 0.195 & 0.137 & & & & 0.069 & & & & & & & 0.857 & 0.121 & 0.049 & 0.031 \\
\hline Russia & 0.251 & 0.208 & & & & 0.111 & & & 0.427 & & & & & 0.120 & 0.067 & 0.110 \\
\hline South Africa & 0.188 & 0.130 & 2.010 & 0.151 & 4.425 & 0.114 & 14.150 & 0.386 & 0.879 & 0.459 & 0.041 & 0.002 & 0.624 & 0.140 & 0.041 & 0.062 \\
\hline Singapore & 0.219 & 0.184 & 2.531 & 0.152 & 4.146 & 0.090 & 13.210 & 0.375 & 0.547 & 0.460 & 0.033 & 0.004 & 0.800 & 0.179 & 0.050 & 0.016 \\
\hline Spain & 0.278 & 0.208 & 2.508 & 0.121 & 4.156 & 0.063 & 14.310 & 0.324 & 0.887 & 0.438 & 0.046 & 0.004 & 0.873 & 0.311 & 0.032 & 0.030 \\
\hline Sweden & 0.199 & 0.141 & 2.594 & 0.134 & 4.322 & 0.041 & 13.440 & 0.220 & 0.861 & 0.521 & 0.048 & 0.029 & 0.455 & 0.127 & 0.026 & 0.014 \\
\hline Switzerland & 0.208 & 0.157 & 2.482 & 0.111 & 4.289 & 0.057 & 13.420 & 0.267 & 0.707 & 0.566 & 0.049 & 0.034 & 0.344 & 0.236 & 0.021 & 0.010 \\
\hline Thailand & 0.329 & 0.267 & 2.435 & 0.133 & 3.629 & 0.104 & 13.760 & 0.435 & 0.615 & 0.339 & 0.056 & 0.000 & 0.989 & 0.084 & 0.045 & 0.026 \\
\hline
\end{tabular}




\begin{tabular}{lllllllllllllllllll} 
Turkey & 0.244 & 0.200 & 1.676 & 0.142 & 3.882 & 0.090 & 14.070 & 0.332 & 0.455 & 0.493 & 0.044 & 0.003 & 0.589 & 0.206 & 0.040 & 0.093 \\
Taiwan & 0.213 & 0.193 & 2.742 & 0.074 & 2.682 & 0.071 & 13.180 & 0.334 & 0.343 & 0.524 & 0.040 & 0.020 & 0.297 & 0.093 & 0.037 & 0.013 \\
United Kingdom & 0.211 & 0.151 & 2.968 & 0.152 & 4.816 & 0.066 & 13.760 & 0.294 & 0.849 & 0.445 & 0.045 & 0.015 & 0.608 & 0.230 & 0.023 & 0.019 \\
United States & 0.238 & 0.171 & 4.321 & 0.084 & 4.556 & 0.051 & 14.020 & 0.312 & 0.823 & 0.429 & 0.046 & 0.018 & 0.542 & 0.126 & 0.021 & 0.026 \\
& & & & & & & & & & & & & & & & & & \\
All countries & 0.223 & 0.183 & 3.023 & 0.102 & 4.068 & 0.053 & 13.760 & 0.316 & 0.538 & 0.480 & 0.042 & 0.016 & 0.490 & 0.176 & 0.027 & 0.020 \\
\hline
\end{tabular}




\section{Table 2: The Effect of Media News on the Speed of Leverage Adjustment - Baseline Results}

This table reports the regression results for the effect of the news media on the speed of leverage adjustment (SOA). We estimate Equation (6)

$$
\Delta L E V_{i j, t+1}=\alpha+\boldsymbol{\beta}^{\prime}(N E W S \times D L E V)_{i j, t}+\gamma^{\prime}(\boldsymbol{Z} \times D L E V)_{i j, t}+e_{i j, t+1},
$$

where the dependent variable $(\triangle L E V)$ is the observed change in either book leverage $(\triangle B L E V)$ or market leverage $(\triangle M L E V)$. NEWS is a media news variable (NewsCove or NewsTone). NewsCove is the extent of news coverage for a firm in a given year, which is defined as the natural logarithm of one plus the number of news articles that cover news events for the firm in that year. NewsTone is the tone of news for a firm in a given year, which is calculated as the average of the event sentiment score $(E S S)$ for the firm in that year. $D L E V$ is the deviation from target leverage, estimated from Equation (3) using the Blundell and Bond (1998) (two-step) SYSGMM estimator. $Z$ is vector of the determinants of the leverage SOA, including an above-target leverage dummy variable $(O V E R)$ that equals one if the firm is over-levered relative to target leverage, and zero otherwise, a financing deficit dummy variable $(D E F)$ that equals one if the firm has a financing deficit, and zero otherwise, dividend yields (DY), and annual GDP growth $(G G D P)$. Country, industry, and year fixed effects (CIY) are included in all models. The variable definitions are in Appendix A. Standard errors are bootstrapped and reported in parentheses. $* * *, * *$, and * indicate significance at the $1 \%, 5 \%$, and $10 \%$ levels, respectively.

\begin{tabular}{|c|c|c|c|c|c|c|}
\hline \multirow[b]{2}{*}{ Variables } & \multicolumn{2}{|c|}{ News Coverage } & \multicolumn{2}{|c|}{ News Tone } & \multicolumn{2}{|c|}{ All News Variables } \\
\hline & $\begin{array}{c}\triangle B L E V_{t+1} \\
\text { (1) }\end{array}$ & $\begin{array}{c}\Delta M L E V_{t+1} \\
\text { (2) }\end{array}$ & $\begin{array}{c}\Delta B L E V_{t+1} \\
\text { (3) }\end{array}$ & $\begin{array}{c}\Delta M L E V_{t+1} \\
(4)\end{array}$ & $\begin{array}{c}\Delta B L E V_{t+1} \\
(5)\end{array}$ & $\begin{array}{c}\Delta M L E V_{t+1} \\
(6)\end{array}$ \\
\hline NewsCove $\times D L E V$ & $\begin{array}{c}0.105^{* * * *} \\
(0.008)\end{array}$ & $\begin{array}{c}0.061 * * * \\
(0.005)\end{array}$ & & & $\begin{array}{c}0.099 * * * \\
(0.008)\end{array}$ & $\begin{array}{c}0.056 * * * \\
(0.005)\end{array}$ \\
\hline NewsTone $\times$ DLEV & & & $\begin{array}{c}0.676 * * * \\
(0.062)\end{array}$ & $\begin{array}{c}0.584 * * * \\
(0.039)\end{array}$ & $\begin{array}{c}0.606 * * * \\
(0.050)\end{array}$ & $\begin{array}{c}0.552^{* * *} \\
(0.040)\end{array}$ \\
\hline$O V E R \times D L E V$ & $\begin{array}{c}0.040 \\
(0.035)\end{array}$ & $\begin{array}{c}0.152^{* * * *} \\
(0.023)\end{array}$ & $\begin{array}{c}0.214 * * * \\
(0.029)\end{array}$ & $\begin{array}{c}0.262 * * * \\
(0.022)\end{array}$ & $\begin{array}{c}0.036 \\
(0.033)\end{array}$ & $\begin{array}{c}0.159 * * * \\
(0.020)\end{array}$ \\
\hline$D E F \times D L E V$ & $\begin{array}{c}0.061 * * \\
(0.030)\end{array}$ & $\begin{array}{c}0.024 \\
(0.017)\end{array}$ & $\begin{array}{c}0.156^{* * * *} \\
(0.024)\end{array}$ & $\begin{array}{c}0.085 * * * \\
(0.019)\end{array}$ & $\begin{array}{c}0.073 * * * \\
(0.028)\end{array}$ & $\begin{array}{c}0.040 * * \\
(0.018)\end{array}$ \\
\hline$D Y \times D L E V$ & $\begin{array}{c}-0.017 * * \\
(0.007)\end{array}$ & $\begin{array}{c}0.002 \\
(0.004)\end{array}$ & $\begin{array}{l}-0.002 \\
(0.005)\end{array}$ & $\begin{array}{c}0.005 \\
(0.004)\end{array}$ & $\begin{array}{c}-0.020 * * * \\
(0.006)\end{array}$ & $\begin{array}{l}-0.004 \\
(0.005)\end{array}$ \\
\hline$G G D P \times D L E V$ & $\begin{array}{c}5.328 * * * \\
(0.639)\end{array}$ & $\begin{array}{c}3.351 * * * \\
(0.420)\end{array}$ & $\begin{array}{c}6.372 * * * \\
(0.535)\end{array}$ & $\begin{array}{c}3.224 * * * \\
(0.345)\end{array}$ & $\begin{array}{c}3.891 * * * \\
(0.595)\end{array}$ & $\begin{array}{c}2.165 * * * \\
(0.377)\end{array}$ \\
\hline Fixed effects & CIY & CIY & CIY & CIY & CIY & CIY \\
\hline Observations & 33,267 & 33,267 & 33,267 & 33,267 & 33,267 & 33,267 \\
\hline R-squared & $7.4 \%$ & $16.7 \%$ & $6.9 \%$ & $17.0 \%$ & $7.8 \%$ & $17.5 \%$ \\
\hline
\end{tabular}




\section{Table 3: Alternative Measure of SOA and Media News, and Alternative Regression Method}

This table reports the regression results for the effect of the news media on the speed of leverage adjustment (SOA). We estimate Equation (6)

$$
\Delta L E V_{i j, t+1}=\alpha+\boldsymbol{\beta}^{\prime}(N E W S \times D L E V)_{i j, t}+\gamma^{\prime}(\boldsymbol{Z} \times D L E V)_{i j, t}+e_{i j, t+1},
$$

where the dependent variable $(\triangle L E V)$ is the observed change in either book leverage $(\triangle B L E V)$ or market leverage $(\triangle M L E V)$. NEWS is a media news variable (NewsCove or NewsTone). NewsCove is the extent of news coverage for a firm in a given year, which is defined as the natural logarithm of one plus the number of news articles that cover news events for the firm in that year. NewsTone is the tone of news for a firm in a given year, which is calculated as the average of the event sentiment score $(E S S)$ for the firm in that year. $D L E V$ is the deviation from target leverage, estimated from Equation (3) using the Blundell and Bond (1998) (two-step) SYSGMM estimator. $Z$ is vector of the determinants of the leverage SOA. In Panel A, Models (1) and (2) report the results for measures of leverage that capture active leverage adjustments. Models (3) and (4) report the results obtained with DLEV being estimated using the DPF estimator (Elsas and Florysiak, 2015). Panel B reports the results for NewsFirm, which is a measure of the firm-specific information contained in news stories for a firm in a given year. Country, industry, and year fixed effects (CIY) are included in all models. The variable definitions are in Appendix A. Standard errors are bootstrapped and reported in parentheses. $* * *, * *$, and $*$ indicate significance at the $1 \%, 5 \%$, and $10 \%$ levels, respectively.

\begin{tabular}{|c|c|c|c|c|}
\hline \multicolumn{5}{|c|}{ Panel A: Alternative Measure of Leverage SOA and Alternative Regression Method } \\
\hline \multirow[b]{2}{*}{ Variables } & \multicolumn{2}{|c|}{ Active SOA } & \multicolumn{2}{|c|}{ DPF } \\
\hline & $\begin{array}{c}\triangle B L E V_{t+1} \\
(1)\end{array}$ & $\begin{array}{c}\Delta M L E V_{t+1} \\
\text { (2) }\end{array}$ & $\begin{array}{c}\triangle B L E V_{t+1} \\
\text { (3) }\end{array}$ & $\begin{array}{c}\Delta M L E V_{t+1} \\
(4)\end{array}$ \\
\hline NewsCove $\times D L E V$ & $\begin{array}{c}0.078 * * * \\
(0.007)\end{array}$ & $\begin{array}{c}0.059 * * * \\
(0.006)\end{array}$ & $\begin{array}{c}0.117 * * * \\
(0.009)\end{array}$ & $\begin{array}{c}0.131 * * * \\
(0.008)\end{array}$ \\
\hline NewsTone $\times D L E V$ & $\begin{array}{c}0.276 * * * \\
(0.078)\end{array}$ & $\begin{array}{c}0.409 * * * \\
(0.055)\end{array}$ & $\begin{array}{c}0.710^{* * * *} \\
(0.088)\end{array}$ & $\begin{array}{c}0.442 * * * \\
(0.076)\end{array}$ \\
\hline$O V E R \times D L E V$ & $\begin{array}{c}0.098 * * \\
(0.040)\end{array}$ & $\begin{array}{c}0.109 * * * \\
(0.029)\end{array}$ & $\begin{array}{l}0.070^{*} \\
(0.039)\end{array}$ & $\begin{array}{c}0.438 * * * \\
(0.034)\end{array}$ \\
\hline$D E F \times D L E V$ & $\begin{array}{c}0.154 * * * \\
(0.031)\end{array}$ & $\begin{array}{c}0.174 * * * \\
(0.024)\end{array}$ & $\begin{array}{c}0.146 * * * \\
(0.033)\end{array}$ & $\begin{array}{c}0.254 * * * \\
(0.026)\end{array}$ \\
\hline$D Y \times D L E V$ & $\begin{array}{c}-0.035^{* * *} \\
(0.006)\end{array}$ & $\begin{array}{c}-0.036 * * * \\
(0.005)\end{array}$ & $\begin{array}{c}-0.020 * * * \\
(0.007)\end{array}$ & $\begin{array}{c}0.019 * * * \\
(0.006)\end{array}$ \\
\hline$G G D P \times D L E V$ & $\begin{array}{c}3.411 * * * \\
(0.660)\end{array}$ & $\begin{array}{c}2.918 * * * \\
(0.538)\end{array}$ & $\begin{array}{c}3.358 * * * \\
(0.693)\end{array}$ & $\begin{array}{c}2.788 * * * \\
(0.750)\end{array}$ \\
\hline Fixed effects & CIY & CIY & CIY & CIY \\
\hline Observations & 33,267 & 33,267 & 33,267 & 33,267 \\
\hline R-squared & $9.1 \%$ & $18.8 \%$ & $7.5 \%$ & $20.5 \%$ \\
\hline
\end{tabular}




\begin{tabular}{|c|c|c|c|c|}
\hline \multicolumn{5}{|c|}{ Panel B: Alternative Measure of Media News } \\
\hline \multirow[b]{2}{*}{ Variables } & \multicolumn{2}{|c|}{ Firm-specific News } & \multicolumn{2}{|c|}{ All News Variables } \\
\hline & $\begin{array}{c}\triangle B L E V_{t+1} \\
(1)\end{array}$ & $\begin{array}{c}\Delta M L E V_{t+1} \\
(2)\end{array}$ & $\begin{array}{c}\triangle B L E V_{t+1} \\
\text { (3) }\end{array}$ & $\begin{array}{c}\Delta M L E V_{t+1} \\
(4)\end{array}$ \\
\hline NewsFirm $\times$ DLEV & $\begin{array}{c}0.055^{* * * *} \\
(0.005)\end{array}$ & $\begin{array}{c}0.029 * * * \\
(0.003)\end{array}$ & $\begin{array}{c}0.027 * * * \\
(0.005)\end{array}$ & $\begin{array}{c}0.016 * * * \\
(0.003)\end{array}$ \\
\hline NewsCove $\times D L E V$ & & & $\begin{array}{c}0.081 * * * \\
(0.009)\end{array}$ & $\begin{array}{c}0.044 * * * \\
(0.005)\end{array}$ \\
\hline NewsTone $\times$ DLEV & & & $\begin{array}{c}0.584 * * * \\
(0.061)\end{array}$ & $\begin{array}{c}0.562 * * * \\
(0.046)\end{array}$ \\
\hline$O V E R \times D L E V$ & $\begin{array}{c}0.123 * * * \\
(0.033)\end{array}$ & $\begin{array}{c}0.211 * * * \\
(0.021)\end{array}$ & $\begin{array}{c}0.021 \\
(0.040)\end{array}$ & $\begin{array}{r}0.155^{* * * *} \\
(0.027)\end{array}$ \\
\hline$D E F \times D L E V$ & $\begin{array}{l}0.047 * \\
(0.025)\end{array}$ & $\begin{array}{c}0.009 \\
(0.019)\end{array}$ & $\begin{array}{c}0.044 \\
(0.029)\end{array}$ & $\begin{array}{c}0.013 \\
(0.018)\end{array}$ \\
\hline$D Y \times D L E V$ & $\begin{array}{c}-0.018 * * * \\
(0.006)\end{array}$ & $\begin{array}{c}0.000 \\
(0.005)\end{array}$ & $\begin{array}{c}-0.030 * * * \\
(0.008)\end{array}$ & $\begin{array}{c}-0.009 * * \\
(0.004)\end{array}$ \\
\hline$G G D P \times D L E V$ & $\begin{array}{c}6.088 * * * \\
(0.591)\end{array}$ & $\begin{array}{c}3.924 * * * \\
(0.364)\end{array}$ & $\begin{array}{c}3.310 * * * \\
(0.579)\end{array}$ & $\begin{array}{c}2.094 * * * \\
(0.444)\end{array}$ \\
\hline Fixed effects & CIY & CIY & CIY & CIY \\
\hline Observations & 29,828 & 29,828 & 29,828 & 29,828 \\
\hline R-squared & $7.2 \%$ & $16.8 \%$ & $8.0 \%$ & $17.9 \%$ \\
\hline
\end{tabular}




\section{Table 4: Different Types of News}

This table reports the regression results for the effect of the news media on the speed of leverage adjustment (SOA). We estimate Equation (6) where the dependent variable $(\triangle L E V)$ is the observed change in either book leverage ( $\triangle B L E V)$ or market leverage $(\triangle M L E V)$. NewsCove is the extent of news coverage for a firm in a given year, which is defined as the natural logarithm of one plus the number of news articles that cover news events for the firm in that year. NewsTone is the tone of news for a firm in a given year, which is calculated as the average of the event sentiment score (ESS) for the firm in that year. DLEV is the deviation from target leverage, estimated from Equation (3) using the Blundell and Bond (1998) (two-step) SYSGMM estimator. $Z$ is vector of the determinants of the leverage SOA. Models (1) and (2) report the results for firm-initiated news. Models (3) and (4) report the results for press-initiated news. Models (5) and (6) report the results for non-financial news. Country, industry, and year fixed effects (CIY) are included in all models. The variable definitions are in Appendix A. Standard errors are bootstrapped and reported in parentheses. ${ }^{* *},{ }^{* *}$, and $*$ indicate significance at the $1 \%, 5 \%$, and $10 \%$ levels, respectively.

\begin{tabular}{|c|c|c|c|c|c|c|}
\hline \multirow[b]{2}{*}{ Variables } & \multicolumn{2}{|c|}{ Firm-initiated News } & \multicolumn{2}{|c|}{ Press-initiated News } & \multicolumn{2}{|c|}{ Non-financial News } \\
\hline & $\begin{array}{c}\Delta B L E V_{t+1} \\
(1)\end{array}$ & $\begin{array}{c}\Delta M L E V_{t+1} \\
\text { (2) }\end{array}$ & $\begin{array}{c}\triangle B L E V_{t+1} \\
\text { (3) }\end{array}$ & $\begin{array}{c}\Delta M L E V_{t+1} \\
(4)\end{array}$ & $\begin{array}{c}\triangle B L E V_{t+1} \\
(5)\end{array}$ & $\begin{array}{c}\Delta M L E V_{t+1} \\
(6)\end{array}$ \\
\hline NewsCove $\times D L E V$ & $\begin{array}{c}0.131^{* * *} \\
(0.016)\end{array}$ & $\begin{array}{c}0.058^{* * *} \\
(0.012)\end{array}$ & $\begin{array}{c}0.092^{* * *} \\
(0.008)\end{array}$ & $\begin{array}{c}0.048^{* * *} \\
(0.005)\end{array}$ & $\begin{array}{c}0.090^{* * *} \\
(0.007)\end{array}$ & $\begin{array}{c}0.049^{* * *} * \\
(0.006)\end{array}$ \\
\hline NewsTone $\times$ DLEV & $\begin{array}{c}0.370^{* *} \\
(0.146)\end{array}$ & $\begin{array}{c}0.100 \\
(0.088)\end{array}$ & $\begin{array}{c}0.325^{* * *} \\
(0.063)\end{array}$ & $\begin{array}{c}0.113^{* *} \\
(0.049)\end{array}$ & $\begin{array}{c}0.307 * * * \\
(0.069)\end{array}$ & $\begin{array}{c}0.113^{* * *} \\
(0.039)\end{array}$ \\
\hline$O V E R \times D L E V$ & $\begin{array}{l}-0.010 \\
(0.058)\end{array}$ & $\begin{array}{c}0.216^{* * *} \\
(0.042)\end{array}$ & $\begin{array}{l}0.059^{*} \\
(0.030)\end{array}$ & $\begin{array}{c}0.178 * * * \\
(0.023)\end{array}$ & $\begin{array}{l}0.063 * \\
(0.035)\end{array}$ & $\begin{array}{c}0.174 * * * \\
(0.020)\end{array}$ \\
\hline$D E F \times D L E V$ & $\begin{array}{c}0.155^{* * *} \\
(0.057)\end{array}$ & $\begin{array}{c}0.101 * * * \\
(0.034)\end{array}$ & $\begin{array}{c}0.077^{* *} \\
(0.030)\end{array}$ & $\begin{array}{l}0.035^{*} \\
(0.019)\end{array}$ & $\begin{array}{c}0.071^{* * *} \\
(0.024)\end{array}$ & $\begin{array}{c}0.033 \\
(0.020)\end{array}$ \\
\hline$D Y \times D L E V$ & $\begin{array}{c}-0.029 * * * \\
(0.008)\end{array}$ & $\begin{array}{l}-0.011 \\
(0.007)\end{array}$ & $\begin{array}{c}-0.017 * * * \\
(0.005)\end{array}$ & $\begin{array}{c}0.002 \\
(0.004)\end{array}$ & $\begin{array}{c}-0.016^{* * *} \\
(0.006)\end{array}$ & $\begin{array}{c}0.003 \\
(0.003)\end{array}$ \\
\hline$G G D P \times D L E V$ & $\begin{array}{c}8.796^{* * *} \\
(1.251)\end{array}$ & $\begin{array}{c}4.697 * * * \\
(0.907)\end{array}$ & $\begin{array}{c}5.121^{* * *} \\
(0.496)\end{array}$ & $\begin{array}{c}3.504^{* * *} \\
(0.363)\end{array}$ & $\begin{array}{c}5.300^{* * *} \\
(0.701)\end{array}$ & $\begin{array}{c}3.518^{* * *} \\
(0.376)\end{array}$ \\
\hline Fixed effects & CIY & CIY & CIY & CIY & CIY & CIY \\
\hline Observations & 12,894 & 12,894 & 33,052 & 33,052 & 33,169 & 33,169 \\
\hline R-squared & $8.5 \%$ & $22.5 \%$ & $7.2 \%$ & $16.5 \%$ & $7.3 \%$ & $16.5 \%$ \\
\hline
\end{tabular}




\section{Table 5: Controlling for Additional Macro- and Firm-level Variables}

This table reports the regression results for the effect of the news media on the speed of leverage adjustment (SOA) after controlling for additional country-level variables and firm-fixed effects (Panel A), as well as firm-specific characteristics (Panel B). We estimate Equation (6) where the dependent variable ( $\triangle L E V$ ) is the observed change in either book leverage $(\triangle B L E V)$ or market leverage $(\triangle M L E V)$. News Cove is the extent of news coverage for a firm in a given year, which is defined as the natural logarithm of one plus the number of news articles that cover news events for the firm in that year. NewsTone is the tone of news for a firm in a given year, which is calculated as the average of the event sentiment score $(E S S)$ for the firm in that year. $D L E V$ is the deviation from target leverage, estimated from Equation (3) using the Blundell and Bond (1998) (two-step) SYSGMM estimator. In Models (1) and (2) of Panel A, we estimate Equation (6) but add three interaction terms: one between the deviation from target leverage $(D L E V)$ and above-target leverage interacted with a financing surplus status $(O V E R \times S U R P L U S)$ and two interactions between $D L E V$ and additional country-level variables (MCAP and FIN EMPHASIS). MCAP is the ratio of stock market capitalization to GDP. FIN_EMPHASIS is a dummy variable that equals one if the financial system structure is bankbased or market-based, and zero otherwise. In Models (1) and (2) of Panel B, we estimate Equation (6) but add interaction terms between the deviation from target leverage (DLEV) and additional firm-specific characteristics and macro-level factors. These additional variables include profitability $(R O A)$, market-to-book $(M B)$, non-debt tax shields $(D E P)$, firm size $(S I Z E)$, asset tangibility $(T A N G)$, research and development $(R \& D)$ expenditures, an R\&D dummy $(R \& D D)$, effective tax rates $(T A X)$, liquidity $(L I Q U I D)$, and the inflation rate (INFL). Country, industry, and year fixed effects (CIY) are included in Models (1) and (2) of both Panels A and B. Models (3) and (4) of both Panels A and B include firm and year fixed effects (FY). The variable definitions are in Appendix A. Standard errors are bootstrapped and reported in parentheses. ${ }^{* *}, * *$, and $*$ indicate significance at the $1 \%, 5 \%$, and $10 \%$ levels, respectively.

\begin{tabular}{|c|c|c|c|c|}
\hline \multicolumn{5}{|c|}{ Panel A: Controlling for Additional Macro-Level Variables and Firm Fixed Effects } \\
\hline \multirow[b]{2}{*}{ Variables } & \multicolumn{2}{|c|}{ Additional Macro Variables } & \multicolumn{2}{|c|}{ Firm Fixed Effects } \\
\hline & $\begin{array}{c}\Delta B L E V_{t+1} \\
(1)\end{array}$ & $\begin{array}{c}\Delta M L E V_{t+1} \\
\text { (2) }\end{array}$ & $\begin{array}{c}\Delta B L E V_{t+1} \\
\text { (3) }\end{array}$ & $\begin{array}{c}\Delta M L E V_{t+1} \\
(4)\end{array}$ \\
\hline NewsCove $\times D L E V$ & $\begin{array}{c}0.045^{* * *} \\
(0.010)\end{array}$ & $\begin{array}{c}0.015^{* * *} \\
(0.006)\end{array}$ & $\begin{array}{c}0.299 * * * \\
(0.013)\end{array}$ & $\begin{array}{c}0.211 * * * \\
(0.012)\end{array}$ \\
\hline NewsTone $\times D L E V$ & $\begin{array}{c}0.583 * * * \\
(0.054)\end{array}$ & $\begin{array}{c}0.523 * * * \\
(0.042)\end{array}$ & $\begin{array}{c}0.499 * * * \\
(0.065)\end{array}$ & $\begin{array}{c}0.515^{* * *} \\
(0.044)\end{array}$ \\
\hline$O V E R \times D L E V$ & $\begin{array}{c}-0.150^{* * *} \\
(0.050)\end{array}$ & $\begin{array}{l}-0.021 \\
(0.031)\end{array}$ & $\begin{array}{c}0.082 \\
(0.057)\end{array}$ & $\begin{array}{c}0.078^{* *} \\
(0.032)\end{array}$ \\
\hline$D E F \times D L E V$ & $\begin{array}{c}0.170^{* * *} \\
(0.042)\end{array}$ & $\begin{array}{c}0.183^{* * *} \\
(0.023)\end{array}$ & $\begin{array}{c}0.337 * * * \\
(0.052)\end{array}$ & $\begin{array}{c}0.237^{* * *} \\
(0.033)\end{array}$ \\
\hline$O V E R \times S U R P L U S \times D L E V$ & $\begin{array}{c}0.356^{* * *} \\
(0.057)\end{array}$ & $\begin{array}{c}0.350 * * * \\
(0.032)\end{array}$ & $\begin{array}{c}0.394 * * * \\
(0.073)\end{array}$ & $\begin{array}{c}0.340^{* * *} \\
(0.045)\end{array}$ \\
\hline$D Y \times D L E V$ & $\begin{array}{c}-0.034 * * * \\
(0.008)\end{array}$ & $\begin{array}{c}-0.018 * * * \\
(0.005)\end{array}$ & $\begin{array}{c}0.023^{* *} \\
(0.010)\end{array}$ & $\begin{array}{l}0.011 * \\
(0.007)\end{array}$ \\
\hline$G G D P \times D L E V$ & $\begin{array}{c}2.424 * * * \\
(0.748)\end{array}$ & $\begin{array}{c}2.432 * * * \\
(0.352)\end{array}$ & $\begin{array}{c}10.430 * * * \\
(1.224)\end{array}$ & $\begin{array}{c}9.319^{* * *} \\
(0.789)\end{array}$ \\
\hline$M C A P \times D L E V$ & $\begin{array}{c}0.078^{* * *} \\
(0.023)\end{array}$ & $\begin{array}{l}-0.016 \\
(0.013)\end{array}$ & $\begin{array}{c}0.160^{* * * *} \\
(0.050)\end{array}$ & $\begin{array}{l}0.041 * \\
(0.023)\end{array}$ \\
\hline FIN_EMPHASIS $\times D L E V$ & $\begin{array}{c}0.226^{* * *} \\
(0.037)\end{array}$ & $\begin{array}{c}0.209^{* * *} \\
(0.024)\end{array}$ & $\begin{array}{c}0.258 * * * \\
(0.084)\end{array}$ & $\begin{array}{c}0.201 * * * \\
(0.053)\end{array}$ \\
\hline Fixed effects & CIY & CIY & FY & FY \\
\hline Observations & 30,658 & 30,658 & 30,658 & 30,658 \\
\hline R-squared & $8.5 \%$ & $17.6 \%$ & $40.5 \%$ & $47.7 \%$ \\
\hline
\end{tabular}




\begin{tabular}{|c|c|c|c|c|}
\hline \multicolumn{5}{|c|}{ Panel B: Controlling for Additional Firm-level Variables and Firm Fixed Effects } \\
\hline \multirow[b]{2}{*}{ Variables } & \multicolumn{2}{|c|}{ Additional Firm-level Variables } & \multicolumn{2}{|c|}{ Firm Fixed Effects } \\
\hline & $\begin{array}{c}\Delta B L E V_{t+1} \\
\text { (1) }\end{array}$ & $\begin{array}{l}\Delta M L E V_{t+1} \\
\text { (2) }\end{array}$ & $\begin{array}{c}\triangle B L E V_{t+1} \\
\text { (3) }\end{array}$ & $\begin{array}{c}\Delta M L E V_{t+1} \\
\text { (4) }\end{array}$ \\
\hline NewsCove $\times$ DLEV & $\begin{array}{c}0.075^{* * * *} \\
(0.014)\end{array}$ & $\begin{array}{c}0.065 * * * \\
(0.008)\end{array}$ & $\begin{array}{c}0.118 * * * \\
(0.035)\end{array}$ & $\begin{array}{c}0.167 * * * \\
(0.018)\end{array}$ \\
\hline NewsTone $\times$ DLEV & $\begin{array}{c}0.563 * * * \\
(0.046)\end{array}$ & $\begin{array}{c}0.612 * * * \\
(0.035)\end{array}$ & $\begin{array}{c}0.431 * * * \\
(0.071)\end{array}$ & $\begin{array}{c}0.546 * * * \\
(0.048)\end{array}$ \\
\hline$R O A \times D L E V$ & $\begin{array}{c}-0.679 * * * \\
(0.212)\end{array}$ & $\begin{array}{c}-0.794 * * * \\
(0.124)\end{array}$ & $\begin{array}{c}0.039 \\
(0.284)\end{array}$ & $\begin{array}{l}-0.165 \\
(0.175)\end{array}$ \\
\hline$M B \times D L E V$ & $\begin{array}{c}0.131 * * * \\
(0.020)\end{array}$ & $\begin{array}{c}-0.141 * * * \\
(0.010)\end{array}$ & $\begin{array}{c}0.080^{* *} \\
(0.037)\end{array}$ & $\begin{array}{c}-0.109 * * * \\
(0.017)\end{array}$ \\
\hline$D E P \times D L E V$ & $\begin{array}{c}0.240 \\
(0.599)\end{array}$ & $\begin{array}{c}0.183 \\
(0.270)\end{array}$ & $\begin{array}{l}-1.472 * \\
(0.842)\end{array}$ & $\begin{array}{l}-0.053 \\
(0.550)\end{array}$ \\
\hline$S I Z E \times D L E V$ & $\begin{array}{c}-0.095 * * * \\
(0.011)\end{array}$ & $\begin{array}{c}-0.043 * * * \\
(0.007)\end{array}$ & $\begin{array}{c}-0.113 * * * * \\
(0.028)\end{array}$ & $\begin{array}{c}-0.090 * * * \\
(0.012)\end{array}$ \\
\hline$T A N G \times D L E V$ & $\begin{array}{c}-0.201 * * \\
(0.094)\end{array}$ & $\begin{array}{l}-0.122 * \\
(0.068)\end{array}$ & $\begin{array}{c}0.024 \\
(0.202)\end{array}$ & $\begin{array}{l}-0.010 \\
(0.119)\end{array}$ \\
\hline$R \& D \times D L E V$ & $\begin{array}{l}-0.339 \\
(0.937)\end{array}$ & $\begin{array}{c}0.087 \\
(0.278)\end{array}$ & $\begin{array}{l}-0.431 \\
(1.431)\end{array}$ & $\begin{array}{l}-0.577 \\
(0.764)\end{array}$ \\
\hline$R \& D D^{*} D L E V$ & $\begin{array}{c}0.019 \\
(0.037)\end{array}$ & $\begin{array}{c}0.043 * * \\
(0.021)\end{array}$ & $\begin{array}{l}0.124^{*} \\
(0.072)\end{array}$ & $\begin{array}{l}0.080^{*} \\
(0.041)\end{array}$ \\
\hline$T A X \times D L E V$ & $\begin{array}{c}0.001 * * \\
(0.000)\end{array}$ & $\begin{array}{c}0.000 \\
(0.001)\end{array}$ & $\begin{array}{c}0.001 \\
(0.001)\end{array}$ & $\begin{array}{c}0.000 \\
(0.001)\end{array}$ \\
\hline$L I Q U I D \times D L E V$ & $\begin{array}{c}-0.226^{* *} \\
(0.110)\end{array}$ & $\begin{array}{c}-0.236 * * * \\
(0.071)\end{array}$ & $\begin{array}{c}0.257 \\
(0.191)\end{array}$ & $\begin{array}{c}0.095 \\
(0.126)\end{array}$ \\
\hline$I N F L \times D L E V$ & $\begin{array}{l}-0.357 \\
(0.742)\end{array}$ & $\begin{array}{c}1.405^{* * *} \\
(0.486)\end{array}$ & $\begin{array}{c}3.645^{* * * *} \\
(1.341)\end{array}$ & $\begin{array}{c}2.406 * * * \\
(0.773)\end{array}$ \\
\hline$G G D P \times D L E V$ & $\begin{array}{c}0.276 \\
(0.658)\end{array}$ & $\begin{array}{l}-0.601 \\
(0.406)\end{array}$ & $\begin{array}{c}3.062 * * * \\
(0.980)\end{array}$ & $\begin{array}{c}3.106^{* * *} \\
(0.618)\end{array}$ \\
\hline Fixed effects & CIY & CIY & FY & FY \\
\hline Observations & 33,619 & 33,619 & 33,619 & 33,619 \\
\hline R-squared & $9.0 \%$ & $19.4 \%$ & $41.7 \%$ & $48.5 \%$ \\
\hline
\end{tabular}




\section{Table 6: National Newspaper Strikes Results}

This table reports the regression results for the effect of the news media on the speed of leverage adjustment (SOA) for the following model:

$$
\Delta L E V_{i j, t+1}=\alpha+\boldsymbol{\beta}^{\prime}(S T R I K E \times D L E V)_{i j, t}+\boldsymbol{\gamma}^{\prime}(\boldsymbol{Z} \times D L E V)_{i j, t}+e_{i j, t+1},
$$

where the dependent variable $(\triangle L E V)$ is the observed change in market leverage ( $\triangle M L E V)$. DLEV is the deviation from target leverage, which is estimated using the Blundell and Bond (1998) (two-step) SYSGMM. STRIKE captures the effect of a strike and can be either (1) a dummy variable equal to one if there is a newspaper strike in a country in a given year (DUMMY_STRIKE), and zero otherwise, or (2) a count variable equal to the number of newspaper strikes in a country in a given year (NUMBER STRIKE). Country, industry, and year fixed effects (CIY) are included in all models. The variable definitions are in Appendix A. Standard errors reported in parentheses are bootstrapped. ***, **, and $*$ indicate significance at the $1 \%, 5 \%$, and $10 \%$ levels, respectively.

\begin{tabular}{|c|c|c|c|c|}
\hline \multirow[b]{3}{*}{ VARIABLES } & \multicolumn{2}{|c|}{ DUMMY_STRIKE } & \multicolumn{2}{|c|}{ NUMBER_STRIKE } \\
\hline & All Firms & Non-Media Firms & All Firms & Non-Media Firms \\
\hline & $(1)$ & (2) & (3) & (4) \\
\hline DUMMY_STRIKE $\times D L E V$ & $\begin{array}{c}-0.085 * * \\
(0.038)\end{array}$ & $\begin{array}{l}-0.078^{*} \\
(0.043)\end{array}$ & & \\
\hline NUMBER_STRIKE $\times D L E V$ & & & $\begin{array}{c}-0.077 * * \\
(0.036)\end{array}$ & $\begin{array}{c}-0.075^{* *} \\
(0.034)\end{array}$ \\
\hline OVER_UNDER $\times D L E V$ & $\begin{array}{c}0.085^{* * * *} \\
(0.024)\end{array}$ & $\begin{array}{c}0.072 * * * \\
(0.022)\end{array}$ & $\begin{array}{c}0.085 * * * \\
(0.027)\end{array}$ & $\begin{array}{c}0.072 * * * \\
(0.021)\end{array}$ \\
\hline$D E F \_S U R P L U S \times D L E V$ & $\begin{array}{c}-0.105 * * * \\
(0.020)\end{array}$ & $\begin{array}{c}-0.116 * * * \\
(0.023)\end{array}$ & $\begin{array}{c}-0.105 * * * \\
(0.020)\end{array}$ & $\begin{array}{c}-0.116^{* * * *} \\
(0.021)\end{array}$ \\
\hline$D Y \times D L E V$ & $\begin{array}{l}-0.008^{*} \\
(0.004)\end{array}$ & $\begin{array}{l}-0.005 \\
(0.005)\end{array}$ & $\begin{array}{l}-0.008^{*} \\
(0.004)\end{array}$ & $\begin{array}{l}-0.005 \\
(0.005)\end{array}$ \\
\hline$G G D P \times D L E V$ & $\begin{array}{c}1.259 * * * \\
(0.439)\end{array}$ & $\begin{array}{l}1.744 * * * \\
(0.402)\end{array}$ & $\begin{array}{l}1.246^{* * * *} \\
(0.431)\end{array}$ & $\begin{array}{l}1.730 * * * \\
(0.361)\end{array}$ \\
\hline Fixed effects & CIY & CIY & CIY & CIY \\
\hline Observations & 33,267 & 29,062 & 33,267 & 29,062 \\
\hline R-squared & $7.5 \%$ & $7.8 \%$ & $7.5 \%$ & $7.8 \%$ \\
\hline
\end{tabular}




\section{Table 7: Information Dissemination Channel}

This table reports the regression results for the effect of the news media on the speed of leverage adjustment (SOA) conditional on information asymmetry. We estimate an augmented model of Equation (6) where the dependent variable $(\triangle L E V)$ is the observed change in either book leverage $(\triangle B L E V)$ or market leverage $(\triangle M L E V)$. News Cove is the extent of news coverage for a firm in a given year, which is defined as the natural logarithm of one plus the number of news articles that cover news events for the firm in that year. NewsTone is the tone of news for a firm in a given year, which is calculated as the average of the event sentiment score (ESS) for the firm in that year. DLEV is the deviation from target leverage, estimated from Equation (3) using the Blundell and Bond (1998) (two-step) SYSGMM estimator. Our model includes triple interaction terms between NewsCove or NewsTone, DLEV, and IA, where $I A$ is the country-and firm-level information asymmetry. In Panel A, we use three indicator variables based on the accounting standard score index (ACCST) (Models (1) and (2)), the disclosure score index (DISC) (Models (3) and (4)), and the aggregate asymmetric information ( $A A I$ ) (Models (5) and (6)) as proxies for the country-level information asymmetry. In Panel B, we use an indicator based on analyst coverage (ANA) (Models (1) and (2)) and the Big 4 auditor dummy (BIG4) (Models (3) and (4)) as proxies for the firm-level information asymmetry. These indicators equal one if the corresponding variables are greater than their annual median values, and zero otherwise. Industry and year fixed effects (IY) are included in Panel A. Country, industry, and year fixed effects (CIY) are included in Panel B. The variable definitions are in Appendix A. Standard errors are bootstrapped and reported in parentheses. ***, **, and $*$ indicate significance at the $1 \%, 5 \%$, and $10 \%$ levels, respectively.

\begin{tabular}{|c|c|c|c|c|c|c|}
\hline \multicolumn{7}{|c|}{ Panel A: Country-level information asymmetry } \\
\hline \multirow[b]{2}{*}{ Variables } & \multicolumn{2}{|c|}{$I A=A C C S T$} & \multicolumn{2}{|c|}{$I A=D I S C$} & \multicolumn{2}{|c|}{$I A=A A I$} \\
\hline & $\begin{array}{c}\Delta B L E V_{t+1} \\
(1)\end{array}$ & $\begin{array}{c}\Delta M L E V_{t+1} \\
(2)\end{array}$ & $\begin{array}{c}\triangle B L E V_{t+1} \\
(3)\end{array}$ & $\begin{array}{c}\Delta M L E V_{t+1} \\
\text { (4) }\end{array}$ & $\begin{array}{c}\Delta B L E V_{t+1} \\
(5)\end{array}$ & $\begin{array}{c}\Delta M L E V_{t+1} \\
(6)\end{array}$ \\
\hline NewsCove $\times D L E V$ & $\begin{array}{c}0.099 * * * \\
(0.011)\end{array}$ & $\begin{array}{c}0.067 * * * \\
(0.008)\end{array}$ & $\begin{array}{c}0.085 * * * \\
(0.014)\end{array}$ & $\begin{array}{c}0.071 * * * \\
(0.009)\end{array}$ & $\begin{array}{c}0.094 * * * \\
(0.012)\end{array}$ & $\begin{array}{c}0.059 * * * \\
(0.008)\end{array}$ \\
\hline NewsTone $\times$ DLEV & $\begin{array}{c}0.625^{* * * *} \\
(0.064)\end{array}$ & $\begin{array}{c}0.664 * * * \\
(0.050)\end{array}$ & $\begin{array}{c}0.601 * * * \\
(0.072)\end{array}$ & $\begin{array}{c}0.689 * * * \\
(0.055)\end{array}$ & $\begin{array}{c}0.621 * * * \\
(0.070)\end{array}$ & $\begin{array}{c}0.656^{* * *} \\
(0.055)\end{array}$ \\
\hline$I A \times D L E V$ & $\begin{array}{c}0.590 * * * \\
(0.080)\end{array}$ & $\begin{array}{c}0.441 * * * \\
(0.050)\end{array}$ & $\begin{array}{c}0.473 * * * \\
(0.073)\end{array}$ & $\begin{array}{c}0.439 * * * \\
(0.046)\end{array}$ & $\begin{array}{c}0.580 * * * \\
(0.087)\end{array}$ & $\begin{array}{c}0.408 \text { *** } \\
(0.041)\end{array}$ \\
\hline NewsCove $\times D L E V \times I A$ & $\begin{array}{c}-0.107 * * * \\
(0.022)\end{array}$ & $\begin{array}{c}-0.087 * * * \\
(0.015)\end{array}$ & $\begin{array}{c}-0.058 * * \\
(0.027)\end{array}$ & $\begin{array}{c}-0.061 * * * \\
(0.017)\end{array}$ & $\begin{array}{c}-0.101 * * * \\
(0.021)\end{array}$ & $\begin{array}{c}-0.074 * * * \\
(0.013)\end{array}$ \\
\hline NewsTone $\times D L E V \times I A$ & $\begin{array}{l}-0.126 \\
(0.114)\end{array}$ & $\begin{array}{c}-0.244 * * \\
(0.120)\end{array}$ & $\begin{array}{c}-0.221^{* *} \\
(0.101)\end{array}$ & $\begin{array}{c}-0.376 * * * \\
(0.093)\end{array}$ & $\begin{array}{l}-0.117 \\
(0.158)\end{array}$ & $\begin{array}{c}-0.216^{* *} \\
(0.096)\end{array}$ \\
\hline Controls $\times D L E V$ & Yes & Yes & Yes & Yes & Yes & Yes \\
\hline Fixed effects & IY & IY & IY & IY & IY & IY \\
\hline Observations & 32,419 & 32,419 & 26,021 & 26,021 & 30,290 & 30,290 \\
\hline R-squared & $6.5 \%$ & $8.3 \%$ & $6.2 \%$ & $8.6 \%$ & $6.7 \%$ & $8.5 \%$ \\
\hline
\end{tabular}




\begin{tabular}{|c|c|c|c|c|}
\hline \multicolumn{5}{|c|}{ Panel B: Firm-level information asymmetry } \\
\hline \multirow[b]{2}{*}{ Variables } & \multicolumn{2}{|c|}{$I A=A N A$} & \multicolumn{2}{|c|}{$I A=B I G 4$} \\
\hline & $\begin{array}{c}\triangle B L E V_{t+1} \\
\text { (1) }\end{array}$ & $\begin{array}{c}\Delta M L E V_{t+1} \\
(2)\end{array}$ & $\begin{array}{c}\triangle B L E V_{t+1} \\
\text { (3) }\end{array}$ & $\begin{array}{c}\Delta M L E V_{t+1} \\
(4)\end{array}$ \\
\hline NewsCove $\times D L E V$ & $\begin{array}{c}0.163 * * * \\
(0.016)\end{array}$ & $\begin{array}{c}0.111^{* * * *} \\
(0.008)\end{array}$ & $\begin{array}{c}0.144 * * * \\
(0.016)\end{array}$ & $\begin{array}{c}0.094 * * * \\
(0.009)\end{array}$ \\
\hline NewsTone $\times$ DLEV & $\begin{array}{c}0.638 * * * \\
(0.074)\end{array}$ & $\begin{array}{c}0.563 * * * \\
(0.065)\end{array}$ & $\begin{array}{c}0.571 * * * \\
(0.099)\end{array}$ & $\begin{array}{c}0.564 * * * \\
(0.062)\end{array}$ \\
\hline$I A \times D L E V$ & $\begin{array}{c}0.340 * * * \\
(0.053)\end{array}$ & $\begin{array}{c}0.250 * * * \\
(0.037)\end{array}$ & $\begin{array}{c}0.350 * * * \\
(0.059)\end{array}$ & $\begin{array}{c}0.232 * * * \\
(0.045)\end{array}$ \\
\hline NewsCove $\times D L E V \times I A$ & $\begin{array}{c}-0.135 * * * \\
(0.021)\end{array}$ & $\begin{array}{c}-0.105^{* * *} * \\
(0.014)\end{array}$ & $\begin{array}{c}-0.114 * * * \\
(0.023)\end{array}$ & $\begin{array}{c}-0.079 * * * \\
(0.014)\end{array}$ \\
\hline NewsTone $\times D L E V \times I A$ & $\begin{array}{l}-0.114 \\
(0.096)\end{array}$ & $\begin{array}{c}0.041 \\
(0.091)\end{array}$ & $\begin{array}{c}0.028 \\
(0.129)\end{array}$ & $\begin{array}{c}0.012 \\
(0.093)\end{array}$ \\
\hline Controls $\times D L E V$ & Yes & Yes & Yes & Yes \\
\hline Fixed effects & CIY & CIY & CIY & CIY \\
\hline Observations & 33,267 & 33,267 & 32,974 & 32,974 \\
\hline R-squared & $6.3 \%$ & $8.1 \%$ & $6.3 \%$ & $8.2 \%$ \\
\hline
\end{tabular}




\section{Table 8: Governance Channel}

This table reports the regression results for the effect of the news media on the speed of leverage adjustment (SOA) conditional on governance quality. We estimate an augmented model of Equation (6) where the dependent variable $(\triangle L E V)$ is the observed change in either book leverage ( $\triangle B L E V)$ or market leverage ( $\triangle M L E V$ ). News Cove is the extent of news coverage for a firm in a given year, which is defined as the natural logarithm of one plus the number of news articles that cover news events for the firm in that year. NewsTone is the tone of news for a firm in a given year, which is calculated as the average of the event sentiment score (ESS) for the firm in that year. DLEV is the deviation from target leverage, estimated from Equation (3) using the Blundell and Bond (1998) (two-step) SYSGMM estimator. Our model includes triple interaction terms between NewsCove or NewsTone, DLEV , and GOV where GOV is the countryand firm-level governance characteristics. In Panel A, we use the legal origin dummy (COMLAW) (Models (1) and (2)) as well as two indicator variables based on the regulatory quality index (RQUALITY) (Models (3) and (4)) and the good government index (GGOV) (Models (5) and (6)) as proxies for country-level governance characteristics. In Panel B, we use two indicators based on institutional ownership (IO) (Models (1) and (2)) and institutional block ownership (BIO) (Models (3) and (4)) as proxies for the firm-level governance characteristics. These indicators equal one if the corresponding variables are greater than their annual median values, and zero otherwise. Industry and year fixed effects (IY) are included in Panel A. Country, industry, and year fixed effects (CIY) are included in Panel B. The variable definitions are in Appendix A. Standard errors are bootstrapped and reported in parentheses. ***, **, and * indicate significance at the $1 \%, 5 \%$, and $10 \%$ levels, respectively.

\begin{tabular}{|c|c|c|c|c|c|c|}
\hline \multicolumn{7}{|c|}{ Panel A: Country-Level governance } \\
\hline \multirow[b]{2}{*}{ Variables } & \multicolumn{2}{|c|}{$G O V=C O M L A W$} & \multicolumn{2}{|c|}{$G O V=R Q U A L I T Y$} & \multicolumn{2}{|c|}{$G O V=G G O V$} \\
\hline & $\begin{array}{c}\triangle B L E V_{t+1} \\
\text { (1) }\end{array}$ & $\begin{array}{c}\Delta M L E V_{t+1} \\
\text { (2) }\end{array}$ & $\begin{array}{c}\triangle B L E V_{t+1} \\
\text { (3) }\end{array}$ & $\begin{array}{c}\triangle M L E V_{t+1} \\
\text { (4) }\end{array}$ & $\begin{array}{c}\triangle B L E V_{t+1} \\
\text { (5) }\end{array}$ & $\begin{array}{c}\Delta M L E V_{t+1} \\
(6)\end{array}$ \\
\hline NewsCove $\times D L E V$ & $\begin{array}{c}0.120 * * * \\
(0.011)\end{array}$ & $\begin{array}{c}0.076 * * * \\
(0.008)\end{array}$ & $\begin{array}{c}0.112 * * * \\
(0.010)\end{array}$ & $\begin{array}{c}0.074 * * * \\
(0.007)\end{array}$ & $\begin{array}{c}0.086 * * * \\
(0.013)\end{array}$ & $\begin{array}{c}0.059 * * * \\
(0.008)\end{array}$ \\
\hline NewsTone $\times$ DLEV & $\begin{array}{c}0.702 * * * \\
(0.075)\end{array}$ & $\begin{array}{c}0.735 * * * \\
(0.058)\end{array}$ & $\begin{array}{c}0.652 * * * \\
(0.073)\end{array}$ & $\begin{array}{c}0.676 \text { *** } \\
(0.050)\end{array}$ & $\begin{array}{c}0.582 * * * \\
(0.064)\end{array}$ & $\begin{array}{c}0.586 * * * \\
(0.053)\end{array}$ \\
\hline$G O V \times D L E V$ & $\begin{array}{c}0.489 * * * \\
(0.075)\end{array}$ & $\begin{array}{c}0.204 * * * \\
(0.047)\end{array}$ & $\begin{array}{c}0.586 * * * \\
(0.089)\end{array}$ & $\begin{array}{c}0.355^{* * *} \\
(0.055)\end{array}$ & $\begin{array}{c}0.478 * * * \\
(0.069)\end{array}$ & $\begin{array}{c}0.512 * * * \\
(0.043)\end{array}$ \\
\hline NewsCove $* D L E V \times G O V$ & $\begin{array}{c}-0.107 * * * \\
(0.020)\end{array}$ & $\begin{array}{c}-0.050 * * * \\
(0.014)\end{array}$ & $\begin{array}{c}-0.116^{* * * *} \\
(0.024)\end{array}$ & $\begin{array}{c}-0.075 * * * \\
(0.015)\end{array}$ & $\begin{array}{c}-0.075 * * * \\
(0.022)\end{array}$ & $\begin{array}{c}-0.096 * * * \\
(0.013)\end{array}$ \\
\hline NewsTone $* D L E V \times G O V$ & $\begin{array}{c}-0.254 * * \\
(0.124)\end{array}$ & $\begin{array}{c}-0.354 * * * \\
(0.090)\end{array}$ & $\begin{array}{l}-0.235 \\
(0.143)\end{array}$ & $\begin{array}{c}-0.344 * * * \\
(0.095)\end{array}$ & $\begin{array}{l}-0.080 \\
(0.136)\end{array}$ & $\begin{array}{l}-0.163 \\
(0.120)\end{array}$ \\
\hline Controls $\times D L E V$ & Yes & Yes & Yes & Yes & Yes & Yes \\
\hline Fixed effects & IY & IY & IY & IY & IY & IY \\
\hline Observations & 33,267 & 33,267 & 33,267 & 33,267 & 33,267 & 33,267 \\
\hline R-squared & $6.3 \%$ & $8.1 \%$ & $6.5 \%$ & $8.2 \%$ & $6.5 \%$ & $8.5 \%$ \\
\hline
\end{tabular}




\begin{tabular}{|c|c|c|c|c|}
\hline \multicolumn{5}{|l|}{ Panel B: Firm-level governance } \\
\hline \multirow[b]{2}{*}{ Variables } & \multicolumn{2}{|c|}{$G O V=I O$} & \multicolumn{2}{|c|}{$G O V=B I O$} \\
\hline & $\begin{array}{c}\triangle B L E V_{t+1} \\
(1)\end{array}$ & $\begin{array}{c}\Delta M L E V_{t+1} \\
(2)\end{array}$ & $\begin{array}{c}\triangle B L E V_{t+1} \\
(3)\end{array}$ & $\begin{array}{c}\Delta M L E V_{t+1} \\
(4)\end{array}$ \\
\hline NewsCove $\times D L E V$ & $\begin{array}{c}0.127 * * * \\
(0.012)\end{array}$ & $\begin{array}{c}0.080 * * * \\
(0.007)\end{array}$ & $\begin{array}{c}0.105^{* * *} \\
(0.009)\end{array}$ & $\begin{array}{c}0.072 * * * \\
(0.006)\end{array}$ \\
\hline NewsTone $\times$ DLEV & $\begin{array}{c}0.628 * * * \\
(0.069)\end{array}$ & $\begin{array}{c}0.545^{* * *} \\
(0.052)\end{array}$ & $\begin{array}{c}0.606^{* * * *} \\
(0.067)\end{array}$ & $\begin{array}{c}0.576^{* * * *} \\
(0.045)\end{array}$ \\
\hline$G O V \times D L E V$ & $\begin{array}{c}0.290 * * * \\
(0.055)\end{array}$ & $\begin{array}{c}0.333 * * * \\
(0.041)\end{array}$ & $\begin{array}{l}0.189 * \\
(0.098)\end{array}$ & $\begin{array}{c}0.323 * * * \\
(0.084)\end{array}$ \\
\hline NewsCove $\times D L E V \times G O V$ & $\begin{array}{c}-0.089 * * * \\
(0.017)\end{array}$ & $\begin{array}{c}-0.092 * * * \\
(0.012)\end{array}$ & $\begin{array}{l}-0.045^{*} \\
(0.026)\end{array}$ & $\begin{array}{c}-0.086^{* * *} \\
(0.019)\end{array}$ \\
\hline NewsTone $\times D L E V \times G O V$ & $\begin{array}{l}-0.090 \\
(0.119)\end{array}$ & $\begin{array}{c}0.103 \\
(0.086)\end{array}$ & $\begin{array}{c}0.136 \\
(0.191)\end{array}$ & $\begin{array}{c}0.132 \\
(0.155)\end{array}$ \\
\hline Controls $\times D L E V$ & Yes & Yes & Yes & Yes \\
\hline Fixed effects & CIY & CIY & CIY & CIY \\
\hline Observations & 33,267 & 33,267 & 33,267 & 33,267 \\
\hline R-squared & $6.2 \%$ & $8.2 \%$ & $6.2 \%$ & $8.0 \%$ \\
\hline
\end{tabular}




\section{Table 9: Costs and Benefits of Leverage Adjustments}

This table reports the regression results for the effect of the news media on the speed of leverage adjustment (SOA) conditional on the costs and benefits of adjusting to target leverage. We estimate an augmented model of Equation (6) where the dependent variable $(\triangle L E V)$ is the observed change in either book leverage $(\triangle B L E V)$ or market leverage $(\triangle M L E V)$. NewsCove is the extent of news coverage for a firm in a given year, which is defined as the natural logarithm of one plus the number of news articles that cover news events for the firm in that year. NewsTone is the tone of news for a firm in a given year, which is calculated as the average of the event sentiment score (ESS) for the firm in that year. DLEV is the deviation from target leverage, estimated from Equation (3) using the Blundell and Bond (1998) (two-step) SYSGMM estimator. Our model includes triple interaction terms between NewsCove or NewsTone, DLEV, and $A D J C O S T$ or $A D J B E N$, which are indicator variables based on the adjustment costs or benefits, respectively. Specifically, $A D J$ COST is based on the ease of access to equity markets (ACCESS_EQUITY) in Models (1) and (2). $A D J B E N$ is based on ex ante bankruptcy costs (EA_BCOST) in Models (3) and (4) and deviation penalties (DEVP) in Models (5) and (6). These indicators equal one if the corresponding variables are greater than their annual median values, and zero otherwise. Industry and year fixed effects (IY) are included in all models. The variable definitions are in Appendix A. Standard errors are bootstrapped and reported in parentheses. ${ }^{* *},{ }^{* *}$, and * indicate significance at the $1 \%, 5 \%$, and $10 \%$ levels, respectively.

\begin{tabular}{|c|c|c|c|c|c|c|}
\hline \multirow[b]{2}{*}{ Variables } & \multicolumn{2}{|c|}{$\begin{array}{c}\text { ADJ_COST }= \\
\text { ACCESS_EQUITY } \\
\end{array}$} & \multicolumn{2}{|c|}{$\begin{array}{l}A D J \_B E N= \\
E A \_B C O S T\end{array}$} & \multicolumn{2}{|c|}{$\begin{array}{c}A D J \_B E N= \\
D E V P\end{array}$} \\
\hline & $\begin{array}{c}\triangle B L E V_{t+1} \\
(1)\end{array}$ & $\begin{array}{c}\Delta M L E V_{t+1} \\
\text { (2) }\end{array}$ & $\begin{array}{c}\triangle B L E V_{t+1} \\
\text { (3) }\end{array}$ & $\begin{array}{c}\Delta M L E V_{t+1} \\
(4)\end{array}$ & $\begin{array}{c}\triangle B L E V_{t+1} \\
(5)\end{array}$ & $\begin{array}{c}\triangle M L E V_{t+} \\
1 \\
(6) \\
\end{array}$ \\
\hline NewsCove $\times D L E V$ & $\begin{array}{c}0.121 * * * \\
(0.009)\end{array}$ & $\begin{array}{c}0.068^{* * *} \\
(0.009)\end{array}$ & $\begin{array}{c}0.117 * * * \\
(0.007)\end{array}$ & $\begin{array}{c}0.065 * * * \\
(0.005)\end{array}$ & $\begin{array}{c}0.098 * * * \\
(0.012)\end{array}$ & $\begin{array}{c}0.044 * * * \\
(0.008)\end{array}$ \\
\hline NewsTone $\times$ DLEV & $\begin{array}{c}0.698^{* * * *} \\
(0.088)\end{array}$ & $\begin{array}{c}0.746^{* * *} \\
(0.067)\end{array}$ & $\begin{array}{c}0.776^{* * *} \\
(0.079)\end{array}$ & $\begin{array}{l}0.875^{* * *} \\
(0.059)\end{array}$ & $\begin{array}{c}0.673 * * * \\
(0.079)\end{array}$ & $\begin{array}{c}0.717 * * * \\
(0.062)\end{array}$ \\
\hline$A D J \_C O S T \times D L E V$ & $\begin{array}{c}0.390^{* * *} \\
(0.081)\end{array}$ & $\begin{array}{c}0.144 * * * \\
(0.049)\end{array}$ & & & & \\
\hline NewsCove $\times D L E V \times A D J \_C O S T$ & $\begin{array}{c}-0.092 * * * \\
(0.019)\end{array}$ & $\begin{array}{c}-0.031^{* *} \\
(0.015)\end{array}$ & & & & \\
\hline NewsTone $\times D L E V \times A D J \_C O S T$ & $\begin{array}{l}-0.256 \\
(0.169)\end{array}$ & $\begin{array}{c}-0.398 * * * \\
(0.099)\end{array}$ & & & & \\
\hline$A D J \_B E N \times D L E V$ & & & $\begin{array}{c}0.399 * * * \\
(0.070)\end{array}$ & $\begin{array}{c}0.195^{* * * *} \\
(0.047)\end{array}$ & $\begin{array}{c}0.581 * * * \\
(0.072)\end{array}$ & $\begin{array}{c}0.526 * * * \\
(0.057)\end{array}$ \\
\hline NewsCove $\times D L E V \times A D J \_B E N$ & & & $\begin{array}{c}-0.097 * * * \\
(0.022)\end{array}$ & $\begin{array}{c}-0.033 * * \\
(0.016)\end{array}$ & $\begin{array}{c}-0.101 * * * \\
(0.018)\end{array}$ & $\begin{array}{c}-0.084 * * * \\
(0.016)\end{array}$ \\
\hline NewsTone $\times D L E V \times A D J \_B E N$ & & & $\begin{array}{c}-0.370 * * * \\
(0.123)\end{array}$ & $\begin{array}{c}-0.545^{* * *} \\
(0.080)\end{array}$ & $\begin{array}{l}-0.214 \\
(0.166)\end{array}$ & $\begin{array}{c}-0.282 * * \\
(0.114)\end{array}$ \\
\hline Controls $\times D L E V$ & Yes & Yes & Yes & Yes & Yes & Yes \\
\hline Fixed effects & IY & IY & IY & IY & IY & IY \\
\hline Observations & 30,658 & 30,658 & 30,658 & 30,658 & 27,940 & 27,940 \\
\hline R-squared & $6.4 \%$ & $8.2 \%$ & $6.4 \%$ & $8.3 \%$ & $6.7 \%$ & $8.6 \%$ \\
\hline
\end{tabular}




\section{Table 10: News Media Coverage and Leverage Adjustment Activities: Multivariate Analysis}

This table presents the marginal effects from the logistic regressions modeling firms' decision to access capital markets via debt issuances, debt retirements, equity issuances, and equity repurchases. Panels A and B report the results for all types of news (i.e., the whole sample) while Panels $\mathrm{C}$ and D present the results for non-financial news. Debt issuances (D.Issue), debt retirements (D.Retire), and equity issuances (E.Equity) are defined as a security issuance or repurchase of at least $5 \%$ of the book assets. Equity retirements (E.Retire) are defined as a stock repurchase of at least $1.25 \%$ of the book assets. The controls are the same variables used in Equation (2). ***, **, and * indicate significance at the $1 \%, 5 \%$, and 10\% levels, respectively. Country, industry, and year fixed effects (CIY) are included in all panels. The variable definitions are in Appendix A. Standard errors are reported in parentheses. ***, **, and * indicate significance at the $1 \%, 5 \%$, and $10 \%$ levels, respectively.

\begin{tabular}{|c|c|c|c|c|c|c|}
\hline \multicolumn{7}{|c|}{ Panel A: External Financing Activities with Debt Transactions } \\
\hline & \multicolumn{3}{|c|}{ Debt issuance } & \multicolumn{3}{|c|}{ Debt retirement } \\
\hline & (1) & (2) & (3) & (4) & (5) & (6) \\
\hline NewsCove & $\begin{array}{c}0.010^{* * *} \\
(0.003)\end{array}$ & & $\begin{array}{c}0.009 * * * \\
(0.003)\end{array}$ & $\begin{array}{c}0.016^{* * * *} \\
(0.002)\end{array}$ & & $\begin{array}{c}0.017 * * * \\
(0.002)\end{array}$ \\
\hline NewsTone & & $\begin{array}{c}0.031 * * \\
(0.015)\end{array}$ & $\begin{array}{l}-0.006 \\
(0.015)\end{array}$ & & $\begin{array}{c}0.198 * * * \\
(0.011)\end{array}$ & $\begin{array}{c}0.088 * * * \\
(0.011)\end{array}$ \\
\hline Controls & Yes & Yes & Yes & Yes & Yes & Yes \\
\hline Fixed effects & CIY & CIY & CIY & CIY & CIY & CIY \\
\hline Observations & 33,267 & 33,267 & 33,267 & 33,267 & 33,267 & 33,267 \\
\hline Pseudo R-squared & $3.6 \%$ & $3.4 \%$ & $3.7 \%$ & $4.7 \%$ & $2.2 \%$ & $4.9 \%$ \\
\hline
\end{tabular}

Panel B: External Financing Activities with Equity Transactions

\begin{tabular}{|c|c|c|c|c|c|c|}
\hline & \multicolumn{3}{|c|}{ Equity issuance } & \multicolumn{3}{|c|}{ Equity retirement } \\
\hline & (1) & (2) & (3) & (4) & (5) & (6) \\
\hline NewsCove & $\begin{array}{c}0.009 * * * \\
(0.003)\end{array}$ & & $\begin{array}{c}0.014 * * * \\
(0.003)\end{array}$ & $\begin{array}{c}0.011^{* * * *} \\
(0.002)\end{array}$ & & $\begin{array}{c}0.011^{* * * *} \\
(0.002)\end{array}$ \\
\hline NewsTone & & $\begin{array}{c}0.339 * * * \\
(0.016)\end{array}$ & $\begin{array}{c}0.397 * * * \\
(0.017)\end{array}$ & & $\begin{array}{c}-0.360^{* * * *} \\
(0.014)\end{array}$ & $\begin{array}{c}-0.358 * * * \\
(0.014)\end{array}$ \\
\hline Controls & Yes & Yes & Yes & Yes & Yes & Yes \\
\hline Fixed effects & CIY & CIY & CIY & CIY & CIY & CIY \\
\hline Observations & 33,267 & 33,267 & 33,267 & 33,267 & 33,267 & 33,267 \\
\hline Pseudo R-squared & $10.2 \%$ & $12.3 \%$ & $12.8 \%$ & $4.8 \%$ & $7.7 \%$ & $7.8 \%$ \\
\hline \multicolumn{7}{|c|}{ Panel C: External Financing Activities with Debt Transactions } \\
\hline & \multicolumn{3}{|c|}{ Debt issuance } & \multicolumn{3}{|c|}{ Debt retirement } \\
\hline & (1) & (2) & (3) & (4) & (5) & $(6)$ \\
\hline NewsCove & $\begin{array}{c}0.007 * * * \\
(0.003)\end{array}$ & & $\begin{array}{c}0.007 * * * \\
(0.003)\end{array}$ & $\begin{array}{c}0.017 * * * \\
(0.002)\end{array}$ & & $\begin{array}{c}0.017 * * * \\
(0.002)\end{array}$ \\
\hline NewsTone & & $\begin{array}{c}0.041 * * \\
(0.015)\end{array}$ & $\begin{array}{c}0.004 \\
(0.015)\end{array}$ & & $\begin{array}{c}0.188 * * * \\
(0.011)\end{array}$ & $\begin{array}{c}0.081 * * * \\
(0.011)\end{array}$ \\
\hline Controls & Yes & Yes & Yes & Yes & Yes & Yes \\
\hline Fixed effects & CIY & CIY & CIY & CIY & CIY & CIY \\
\hline Observations & 33,198 & 33,198 & 33,198 & 33,198 & 33,198 & 33,198 \\
\hline Pseudo R-squared & $3.6 \%$ & $3.4 \%$ & $3.6 \%$ & $4.7 \%$ & $2.1 \%$ & $4.9 \%$ \\
\hline
\end{tabular}

Panel D: External Financing Activities with Equity Transactions

\begin{tabular}{lcccccc} 
& \multicolumn{3}{c}{ Equity issuance } & & \multicolumn{3}{c}{ Equity retirement } \\
\cline { 2 - 3 } \cline { 5 - 7 } & $(1)$ & $(2)$ & $(3)$ & $(4)$ & $(5)$ & $(6)$ \\
\hline NewsCove & $0.006^{* * *}$ & & $0.012^{* * *}$ & & $0.012^{* * *}$ & $0.012^{* * *}$
\end{tabular}




\begin{tabular}{lcccccc} 
& $(0.003)$ & & $(0.003)$ & $(0.002)$ & & $(0.002)$ \\
NewsTone & & $0.344 * * *$ & $0.401 * * *$ & & $-0.362 * * *$ & $-0.360 * * *$ \\
& & $(0.016)$ & $(0.017)$ & & $(0.014)$ & $(0.014)$ \\
Controls & Yes & Yes & Yes & Yes & Yes & Yes \\
Fixed effects & CIY & CIY & CIY & CIY & CIY & CIY \\
Observations & 33,198 & 33,198 & 33,198 & 33,198 & 33,198 & 33,198 \\
Pseudo R-squared & $10.1 \%$ & $12.4 \%$ & $12.8 \%$ & $4.8 \%$ & $7.8 \%$ & $7.9 \%$ \\
\hline
\end{tabular}




\section{Internet Appendix to}

\section{"News Media Coverage and Corporate Leverage Adjustments"}

This internet appendix provides supplemental analyses to the main results presented in "News Media Coverage and Corporate Leverage Adjustments". Section A reports the data structure. Section B summarizes the subsample analysis. Section C reports the results obtained using the one-stage estimation approach. Section D discusses the results obtained using an instrumental variable approach. Sections E and F analyze the impact of news coverage and content on leverage adjustment activities and the cost of capital, respectively. Finally, Section G examines the nonlinear effect of the news variables on the leverage SOA.

\section{Section A. Data Structure}

Table IA.1 reports the data structure and the mean of the estimated SOA for each country and for the entire sample. Of all the countries in the sample, Japan has the largest number of firms (1,398), followed by the U.S. (1,116), India (648), the U.K. (406), Taiwan (332), Germany (264), and Canada (308). We find that the estimated leverage adjustment speeds are all positive and lie between zero and one as expected. As in Öztekin and Flannery (2012), the patterns of these SOA estimates are broadly similar for market leverage $(M L E V)$ and book leverage $(B L E V)$. For firms in the whole sample, the average estimated SOAs of book and market leverage are 0.23 and 0.38 , respectively, which is consistent with the prediction that a typical firm converges to its optimal capital structure over time.

\section{Section B. Different Subsamples}

We first conduct a subsample analysis for U.S. versus non-U.S. firms. We perform this analysis for two main reasons. First, the U.S. has arguably among the most advanced media industries in the world. In our sample, the average U.S. firm receives by far the highest news 
coverage relative to firms in any other country. Second, an analysis based on a single country does not suffer from the heterogeneity seen in the institutional factors across different countries, which provides a simpler, but cleaner, setting in which to examine our research question. We re-estimate Equation (6) for the subsamples of U.S. versus non-U.S. firms and report the results in Panel A of Table IA.2. We find the interaction terms between the news variables and the leverage deviation to be positive and significant across all models, suggesting that the positive impact of news coverage and content on the leverage SOA is present in both U.S. and non-U.S. firms.

We also re-estimate Equation (6) separately for firms from developed economies and those from emerging markets, as well as those from high- and low-press-freedom countries. This analysis is motivated by the fact that the ability of the news media to produce and disseminate information and the quality of that information depend on a country's degree of economic development and press freedom (Griffin, Hirschey, and Kelly, 2011). A country is defined as a high(low)-press-freedom country if its world press freedom index is above (below) the median score for all the sample countries. We report the results in Panel B of Table IA.2. Across all models, the coefficients on the interaction terms between the news variables and the leverage deviation remain positive and significant. Overall, the results for different subsamples provide further support for $\boldsymbol{H 1 a}$.

\section{Section C. One-Stage Approach}

We have thus far employed the two-stage approach to study the impact of the news variables on the SOA. We now consider an alternative approach based on one-stage estimation. This approach involves substituting Equation (4) into Equation (3), yielding

$$
L E V_{i j, t+1}=\alpha+\left(1-\left(\delta_{0}+\boldsymbol{\beta}^{\prime} N E W S_{i j, t}\right)\right) L E V_{i j, t}+\boldsymbol{\vartheta}^{\prime} \boldsymbol{X}_{i j, t}+\mu_{i}+e_{i j, t+1},
$$

which we can simplify further to yield 


$$
L E V_{i j, t+1}=\alpha+\lambda^{\prime}(N E W S \times L E V)_{i j, t}+\left(1-\delta_{0}\right) L E V_{i j, t}+\boldsymbol{\vartheta}^{\prime} \boldsymbol{X}_{i j, t}+\mu_{i}+e_{i j, t+1},
$$

where $\lambda^{\prime}=-\boldsymbol{\beta}^{\prime}$. In this model, the effect of the news media on the SOA is captured by the coefficients on the interaction terms $(\lambda)$ between alternative measures of news media coverage and leverage, $(N E W S \times L E V)_{i j, t}$. Since $\boldsymbol{\lambda}$ and $\boldsymbol{\beta}$ have the same magnitudes but are opposite in sign, we expect the coefficients, $\lambda$, to be negative.

Because the one-stage regression model, Equation (6'), is a dynamic panel data model, we adopt the SYSGMM estimator, as discussed in Section 3 of the paper. We report the regression results in Table IA.3. Our independent variables of interest are the interaction terms between leverage ( $L E V)$ and the extent of the media's news coverage (NewsCove) and the tone of the news (NewsTone). We find that the coefficients on these interaction terms are negative and highly significant at the $1 \%$ level in Models (1) and (2). These results indicate that news coverage and tone are positively associated with the leverage SOA, supporting hypothesis $\mathrm{HIa}$.

\section{Section D. Instrumental Variable Approach}

To further address the possibility that unobserved omitted variables might be driving the results, we adopt the instrumental variable (IV) estimation approach. We follow the spirit of recent studies (e.g., Gurun and Butler, 2012) and use industry-year medians (excluding the firm of interest) of news coverage (InDNewsCove) and of news tone (InDNewsTone) within each country as instruments for a given firm's news media coverage and tone, respectively. The intuition behind these IVs is that, if the industry in which a firm operates attracts media coverage, then the firm itself is more likely to be covered by the press. On the other hand, it seems less likely that the industry-median news variables (excluding the firm's news) will have a direct impact on the firm's leverage adjustments. We present the IV regression results using these instruments in Table IA.5. In the first stage, we regress the news variables (NewsCove and NewsTone), interacted with DLEV, 
on the instruments interacted with $D L E V$ and the controls. The first-stage results reveal that the instruments are relevant as they are significantly correlated with firm-level news coverage and tone. Importantly, the second-stage results, reported in Models (2), (4), (6), and (8), show positive and significant coefficients on NewsCove $\times D L E V$ and NewsTone $\times D L E V$, suggesting that news coverage and content still have a positive impact on the leverage SOA.

\section{Section E. Media Coverage and Leverage Adjustment Activities - Univariate Analysis}

In this section, we perform a univariate analysis of the impact of news media coverage on leverage adjustment activities. Panels A and B of Table IA.6 report the results for news media coverage and content, respectively. The percentage of firm years in which firms access external markets is reported in Panels A.I and Panel B.I while the size of capital market transactions is reported in Panel A.II and Panel B.II. The results show that the frequency of access to external markets through both debt and equity transactions is significantly higher for firms with high media coverage than for those with low media coverage (Panel A.I). In addition, debt transactions (47\%) appear to be a more important form of adjustment than equity transactions (43\%). The magnitudes of the access, in terms of the amounts of debt issuance and equity issuance (Panel A.II), follow a similar pattern to the frequency of access, as documented in Panel A.I. However, there is no difference in the volume of debt retirement between firms with high media coverage and those with low media coverage, while the former firms retire more equity than the latter.

Regarding the impact of news sentiment, Panel B.I shows that the incidences of debt and equity transactions are higher for firms with positive news than those with negative news. This finding holds for all types of external leverage adjustments, except equity retirement. Firms retire less equity when the news coverage about them is positive. In Panel B.II, we find a similar pattern 
regarding the size of transactions. Overall, the results provide preliminary evidence that the news media facilitates firms' external financing activities and capital structure rebalancing.

\section{Section F. Media Coverage and Cost of Capital}

Our empirical analysis is based on the argument that the news media can reduce the cost of leverage adjustments because it helps reduce information asymmetry, agency costs, and, particularly, the cost of capital. In an attempt to provide some evidence to support this argument, we relate news coverage and content to the cost of capital. We follow Hail and Leuz (2006) and use the average from four implied cost of capital models to proxy for the cost of capital. These models include the residual income valuation model of Claus and Thomas (2001) and Gebhardt, Lee, and Swaminathan (2001), the MPEG model of Easton (2004), and the abnormal earnings growth valuation model of Ohlson and Juettner-Nauroth (2005). We then estimate the effects of NewsCov and NewsTone on the implied cost of capital.

We present the results in Table IA.7. We find that greater news media coverage and more positive news sentiment reduce the cost of capital, as shown by the negative and significant coefficient estimates on NewsCov (Model (1)), NewsTone (Model (2)), and on both variables (Model (3)). Overall, this evidence provides further support for our main argument that the news media can reduce the costs of leverage adjustments, which in turn increases the leverage SOA.

\section{Section G. Nonlinear Effect of News Media on the Speed of Leverage Adjustment}

In this analysis, we examine potential asymmetries and nonlinearities in the relation between news coverage and content and the leverage SOA. First, we examine the strength of this relation for under- and over-levered firms. As mentioned in the paper, our test is motivated by the well-documented finding in the literature that the SOA is strongly determined by deviations from target leverage. Specifically, Byoun (2008) and Faulkender et al. (2012) show that firms' 
adjustments toward target leverage are asymmetric as firms weigh differently positive and negative deviations of their leverage from the target ratio. The preference to preserve debt capacity for future financing needs will result in a slower adjustment when firms are under-levered, while the concern about financial distress costs will lead to a quicker adjustment when firms are overlevered. Following these arguments, to the extent that over-levered firms face higher distress risk, their greater news coverage may reflect more concerns and negative sentiment about such risk, which inversely affects these firms' adjustment activities. Hence, the positive impact of news coverage on the SOA may be less pronounced when firms have above-target leverage. However, firms that have above-target leverage but can still attract positive news stories may take advantage of the positive news tone in the media to revert back to their target leverage. This argument suggests that the impact of news sentiment on the SOA may be stronger when firms are overlevered.

Second, we examine whether the effect of the media's news on the SOA differs for firms with high media coverage or positive news versus those with the opposite characteristics. Our analysis is motivated by existing empirical evidence of a nonlinear impact of news on equity return (i.e., the cost of equity capital). For example, Medovikov (2016) shows that the market reacts strongly and negatively to negative news, but that it appears to discount positive news. Thus, it is possible that the effect of the news media on the SOA is also nonlinear, especially when both news coverage and news sentiment are analyzed concurrently. In particular, greater coverage of news with more positive sentiment may amplify the positive effect of the media's news on the SOA while greater coverage of news with a more negative tone may exacerbate the negative impact of news sentiment on the SOA. 
To test those predictions, we estimate a model based on Equation (6), augmented by three triple interactions between the news variables, the deviation from target leverage, and three dummy variables that capture whether firms are over- or under-levered (OVER), whether they have high media coverage (HIGHCOV), and whether they have positive news content (POSITIVE). $\mathrm{HIGHCOV}$ is an indicator variable that equals one if news coverage is above the median news coverage in a given year, and zero otherwise. POSITIVE is an indicator variable that equals one if the news sentiment score is positive in a given year, and zero otherwise.

We present the results in Table IA.8. Models (1) and (2) show negative coefficients on NewsCov $\times D L E V \times O V E R$, suggesting that the positive impact of media coverage on leverage adjustment speeds is weaker for over-levered firms. This finding is consistent with the conjecture that because over-levered firms are exposed to higher distress risk, their greater news coverage may be associated with less than positive news, thus inversely affecting these firms' adjustment activities and lowering their leverage SOA. When over-levered firms attract more positive news, as captured by the coefficients on NewsTone $\times D L E V \times O V E R$, the positive impact on the SOA of having above-target leverage does become more pronounced as predicted. In Models (3) and (4), again the effect of news coverage seems dependent on whether the news sentiment is positive or negative. There is weak evidence that news coverage has an inverse $\mathrm{U}$-shaped relation with the leverage SOA, as shown by the negative and marginally significant coefficients on NewsCove $\times D L E V \times H I G H C O V$. The positive coefficients on NewsTone $\times D L E V \times H I G H C O V$ indicate that firms covered more intensively by the media and in a more positive tone will make the quickest adjustments. In Models (5) and (6), the coefficients on the interaction terms NewsCove $\times D L E V \times P O S I T I V E$ and NewsTone $\times D L E V \times P O S I T I V E$ are positive and generally significant, again suggesting that the impact of both news variables on leverage adjustments is 
stronger with a positive tone. These results are consistent with our prediction that greater news coverage and more positive news sentiment, when combined together, may amplify their standalone positive effect on the SOA. Overall, there is some evidence of asymmetric and nonlinear effects of the news media on the leverage SOA, conditional on whether firms are over-levered relative to their target leverage, covered by more news, and particularly whether the news articles have a more positive tone.

\section{Additional References}

Claus, J., Thomas, J., 2001. Equity Premia as Low as Three Percent? Evidence from Analysts' Earnings Forecasts for Domestic and International Stock Markets. The Journal of Finance $56,1629-1666$.

Easton, P.D., 2004. PE Ratios, PEG Ratios, and Estimating the Implied Expected Rate of Return on Equity Capital. Accounting Review 79, 73-95.

Gebhardt, W.R., Lee, C.M.C., Swaminathan, B., 2001. Toward an Implied Cost of Capital. Journal of Accounting Research 39, 135-176.

Griffin, J. M., Hirschey, N. H., and Kelly, P. J., 2011. How important is the financial media in global markets? Review of Financial Studies 24, 3941-3992.

Hail, L., Leuz, C., 2006. International Differences in the Cost of Equity Capital: Do Legal Institutions and Securities Regulation Matter? Journal of Accounting Research 44, $485-531$.

Ohlson, J.A., Juettner-Nauroth, B.E., 2005. Expected EPS and EPS Growth as Determinants of Value. Review of Accounting Studies 10, 349-365. 


\section{Table IA.1: Data Structure and Estimates of the Speed of Leverage Adjustment}

This table reports the data structure and the average of the speed of leverage adjustment (SOA) for each country. The study period is from 2000 to 2010. The leverage SOA is estimated following Flannery and Hankins (2013) and adopting the Blundell and Bond (1998) (two-step) SYSGMM for either book leverage (BLEV) or market leverage $(M L E V)$. The variable definitions are in Appendix A.

\begin{tabular}{|c|c|c|c|c|}
\hline \multirow[t]{2}{*}{ Country } & \multicolumn{2}{|c|}{ Data Structure } & \multicolumn{2}{|c|}{ SOA Estimates } \\
\hline & No. of Firms & No. of Obs. & $B L E V$ & MLEV \\
\hline Australia & 215 & 949 & 0.319 & 0.277 \\
\hline Austria & 29 & 156 & 0.080 & 0.105 \\
\hline Belgium & 55 & 302 & 0.426 & 0.284 \\
\hline Canada & 308 & 1,298 & 0.340 & 0.305 \\
\hline China & 42 & 221 & 0.362 & 0.245 \\
\hline Denmark & 36 & 184 & 0.025 & 0.244 \\
\hline Ireland & 33 & 191 & 0.348 & 0.168 \\
\hline Finland & 62 & 256 & 0.192 & 0.318 \\
\hline France & 155 & 664 & 0.356 & 0.268 \\
\hline Germany & 264 & 1,178 & 0.326 & 0.273 \\
\hline Greece & 38 & 140 & 0.334 & 0.356 \\
\hline Hong Kong & 485 & 2,074 & 0.255 & 0.276 \\
\hline Indonesia & 34 & 180 & 0.117 & 0.638 \\
\hline India & 648 & 2,020 & 0.117 & 0.043 \\
\hline Italy & 96 & 396 & 0.152 & 0.132 \\
\hline Japan & 1,398 & 8,206 & 0.163 & 0.145 \\
\hline South Korea & 184 & 668 & 0.098 & 0.244 \\
\hline Mexico & 20 & 117 & 0.346 & 0.152 \\
\hline Malaysia & 85 & 482 & 0.166 & 0.223 \\
\hline Netherlands & 61 & 311 & 0.361 & 0.373 \\
\hline Norway & 72 & 283 & 0.246 & 0.450 \\
\hline Poland & 31 & 102 & 0.210 & 0.351 \\
\hline Russia & 35 & 163 & 0.178 & 0.044 \\
\hline South Africa & 57 & 250 & 0.284 & 0.188 \\
\hline Singapore & 110 & 604 & 0.173 & 0.214 \\
\hline Spain & 67 & 278 & 0.210 & 0.142 \\
\hline Sweden & 118 & 532 & 0.289 & 0.442 \\
\hline Switzerland & 116 & 722 & 0.080 & 0.219 \\
\hline Thailand & 39 & 208 & 0.129 & 0.178 \\
\hline Turkey & 31 & 109 & 0.354 & 0.446 \\
\hline Taiwan & 332 & 1,461 & 0.174 & 0.382 \\
\hline United Kingdom & 406 & 2,347 & 0.228 & 0.345 \\
\hline United States & 1,116 & 6,567 & 0.184 & 0.256 \\
\hline All Countries & 6,778 & 33,267 & 0.228 & 0.381 \\
\hline
\end{tabular}




\section{Table IA.2: Different Subsamples}

This table reports the regression results for the effect of the news media on the speed of leverage adjustment (SOA) for the following model:

$$
\Delta L E V_{i j, t+1}=\alpha+\boldsymbol{\beta}^{\prime}(N E W S \times D L E V)_{i j, t}+\gamma^{\prime}(\boldsymbol{Z} \times D L E V)_{i j, t}+e_{i j, t+1},
$$

where the dependent variable $(\triangle L E V)$ is the observed change in either book leverage $(\triangle B L E V)$ or market leverage ( $\triangle M L E V$ ). NEWS is a media news variable (NewsCove or NewsTone). NewsCove is the extent of news coverage for a firm in a given year, which is defined as the natural logarithm of one plus the number of news articles that cover news events for the firm in that year. NewsTone is the tone of news for a firm in a given year, which is calculated as the average of the event sentiment score (ESS) for the firm in that year. DLEV is the deviation from target leverage, which is estimated using the Blundell and Bond (1998) (two-step) SYSGMM. $\boldsymbol{Z}$ is a vector of the determinants of the leverage SOA. Panel A reports the regression results for U.S. and non-U.S. firms. Panel B reports the regression results for developed and emerging markets (Model (1)-(4)), and countries with high press freedom versus low press freedom (Model (5)-(8)). Country, industry, and year fixed effects (CIY) are included in all models, except Models (1) and (2) of Panel A, where only industry and year fixed effects (IY) are included. The variable definitions are in Appendix A. Standard errors reported in parentheses are bootstrapped. $* * *, * *$, and $*$ indicate significance at the $1 \%, 5 \%$, and $10 \%$ levels, respectively.

\begin{tabular}{|c|c|c|c|c|}
\hline \multicolumn{5}{|c|}{ Panel A: U.S. versus Non-U.S. Firms } \\
\hline \multirow[b]{2}{*}{ Variables } & \multicolumn{2}{|c|}{ U.S. Firms } & \multicolumn{2}{|c|}{ Non-U.S. Firms } \\
\hline & $\begin{array}{c}\Delta B L E V_{t+1} \\
(1)\end{array}$ & $\begin{array}{c}\Delta M L E V_{t+1} \\
\text { (2) }\end{array}$ & $\begin{array}{c}\Delta B L E V_{t+1} \\
(3)\end{array}$ & $\begin{array}{c}\Delta M L E V_{t+1} \\
(4)\end{array}$ \\
\hline NewsCove $* D L E V$ & $\begin{array}{c}0.081 * * * \\
(0.013)\end{array}$ & $\begin{array}{c}0.028^{* *} \\
(0.012)\end{array}$ & $\begin{array}{c}0.088 * * * \\
(0.010)\end{array}$ & $\begin{array}{c}0.057 * * * \\
(0.007)\end{array}$ \\
\hline NewsTone $*$ DLEV & $\begin{array}{c}1.623 * * * \\
(0.354)\end{array}$ & $\begin{array}{c}0.805^{* * * *} \\
(0.240)\end{array}$ & $\begin{array}{c}0.568 * * * \\
(0.057)\end{array}$ & $\begin{array}{c}0.537 * * * \\
(0.038)\end{array}$ \\
\hline$O V E R \_U N D E R * D L E V$ & $\begin{array}{c}-0.178^{* *} \\
(0.084)\end{array}$ & $\begin{array}{c}0.197 * * * \\
(0.044)\end{array}$ & $\begin{array}{c}0.092 * * * \\
(0.032)\end{array}$ & $\begin{array}{c}0.154 * * * \\
(0.023)\end{array}$ \\
\hline$D E F \_S U R P L U S * D L E V$ & $\begin{array}{c}0.182 * * * \\
(0.069)\end{array}$ & $\begin{array}{c}0.096 * * * \\
(0.037)\end{array}$ & $\begin{array}{l}0.052 * \\
(0.029)\end{array}$ & $\begin{array}{l}0.031 * \\
(0.018)\end{array}$ \\
\hline$D Y^{*} D L E V$ & $\begin{array}{c}-0.096^{* * *} \\
(0.021)\end{array}$ & $\begin{array}{c}-0.055^{* * * *} \\
(0.017)\end{array}$ & $\begin{array}{l}-0.007 \\
(0.005)\end{array}$ & $\begin{array}{c}0.003 \\
(0.005)\end{array}$ \\
\hline$G G D P * D L E V$ & $\begin{array}{c}11.509 * * * \\
(2.742)\end{array}$ & $\begin{array}{c}5.802 * * * \\
(1.750)\end{array}$ & $\begin{array}{c}3.619 * * * \\
(0.544)\end{array}$ & $\begin{array}{c}2.070^{* * * *} \\
(0.436)\end{array}$ \\
\hline Fixed effects & IY & IY & CIY & CIY \\
\hline Observations & 6,540 & 6,540 & 26,727 & 26,727 \\
\hline R-squared & $10.8 \%$ & $23.4 \%$ & $7.5 \%$ & $17.4 \%$ \\
\hline
\end{tabular}




\begin{tabular}{|c|c|c|c|c|c|c|c|c|}
\hline \multicolumn{9}{|c|}{ Panel B: Develop versus Emerging Countries; High Press Freedom versus Low Press Freedom Countries } \\
\hline \multirow[b]{2}{*}{ Variables } & \multicolumn{2}{|c|}{ Developed } & \multicolumn{2}{|c|}{ Emerging } & \multicolumn{2}{|c|}{ High Press Freedom } & \multicolumn{2}{|c|}{ Low Press Freedom } \\
\hline & $\begin{array}{c}\Delta B L E V_{t+1} \\
(1)\end{array}$ & $\begin{array}{c}\Delta M L E V_{t+1} \\
(2)\end{array}$ & $\begin{array}{c}\Delta B L E V_{t+1} \\
(3)\end{array}$ & $\begin{array}{c}\Delta M L E V_{t+1} \\
(4)\end{array}$ & $\begin{array}{c}\triangle B L E V_{t+1} \\
(5)\end{array}$ & $\begin{array}{c}\triangle M L E V_{t+1} \\
(6)\end{array}$ & $\begin{array}{c}\Delta B L E V_{t+1} \\
(7)\end{array}$ & $\begin{array}{c}\Delta M L E V_{t+1} \\
(8)\end{array}$ \\
\hline NewsCove*DLEV & $\begin{array}{c}0.114 * * * \\
(0.012)\end{array}$ & $\begin{array}{c}0.059 * * * \\
(0.007)\end{array}$ & $\begin{array}{c}0.087 * * * \\
(0.009)\end{array}$ & $\begin{array}{c}0.054 * * * \\
(0.006)\end{array}$ & $\begin{array}{c}0.076^{* * *} \\
(0.015)\end{array}$ & $\begin{array}{c}0.087 * * * \\
(0.008)\end{array}$ & $\begin{array}{c}0.091 * * * \\
(0.009)\end{array}$ & $\begin{array}{c}0.036 * * * \\
(0.005)\end{array}$ \\
\hline NewsTone*DLEV & $\begin{array}{c}0.628 * * * \\
(0.095)\end{array}$ & $\begin{array}{c}0.542^{* * *} \\
(0.066)\end{array}$ & $\begin{array}{c}0.596 * * * \\
(0.071)\end{array}$ & $\begin{array}{c}0.564 * * * \\
(0.069)\end{array}$ & $\begin{array}{c}0.511 * * * \\
(0.095)\end{array}$ & $\begin{array}{c}0.336^{* * *} \\
(0.048)\end{array}$ & $\begin{array}{c}0.576^{* * *} \\
(0.068)\end{array}$ & $\begin{array}{c}0.618 * * * \\
(0.051)\end{array}$ \\
\hline$O V E R \_U N D E R * D L E V$ & $\begin{array}{c}0.050 \\
(0.055)\end{array}$ & $\begin{array}{c}0.211^{* * *} * \\
(0.035)\end{array}$ & $\begin{array}{c}0.032 \\
(0.041)\end{array}$ & $\begin{array}{c}0.122 * * * \\
(0.024)\end{array}$ & $\begin{array}{c}0.219 * * * \\
(0.064)\end{array}$ & $\begin{array}{c}0.157 * * * \\
(0.039)\end{array}$ & $\begin{array}{l}-0.018 \\
(0.043)\end{array}$ & $\begin{array}{c}0.157 * * * \\
(0.024)\end{array}$ \\
\hline$D E F \_S U R P L U S * D L E V$ & $\begin{array}{c}0.109 * * \\
(0.048)\end{array}$ & $\begin{array}{l}0.053^{*} \\
(0.030)\end{array}$ & $\begin{array}{c}0.037 \\
(0.029)\end{array}$ & $\begin{array}{c}0.029 \\
(0.019)\end{array}$ & $\begin{array}{c}0.028 \\
(0.043)\end{array}$ & $\begin{array}{c}0.033 \\
(0.028)\end{array}$ & $\begin{array}{l}0.068 * \\
(0.041)\end{array}$ & $\begin{array}{c}0.038 * \\
(0.023)\end{array}$ \\
\hline$D Y^{*} D L E V$ & $\begin{array}{c}-0.031 * * * \\
(0.008)\end{array}$ & $\begin{array}{l}-0.002 \\
(0.007)\end{array}$ & $\begin{array}{l}-0.010 \\
(0.008)\end{array}$ & $\begin{array}{l}-0.005 \\
(0.006)\end{array}$ & $\begin{array}{l}-0.001 \\
(0.008)\end{array}$ & $\begin{array}{c}0.012 * * \\
(0.005)\end{array}$ & $\begin{array}{c}-0.032 * * * \\
(0.009)\end{array}$ & $\begin{array}{c}-0.014 * * \\
(0.006)\end{array}$ \\
\hline$G G D P^{*} D L E V$ & $\begin{array}{c}3.495 * * * \\
(0.766)\end{array}$ & $\begin{array}{c}1.790 * * * \\
(0.575)\end{array}$ & $\begin{array}{c}4.196 * * * \\
(0.665)\end{array}$ & $\begin{array}{c}2.496^{* * *} \\
(0.534)\end{array}$ & $\begin{array}{c}2.636^{* * * *} \\
(0.704)\end{array}$ & $\begin{array}{c}0.401 \\
(0.511)\end{array}$ & $\begin{array}{c}9.206 * * * \\
(1.148)\end{array}$ & $\begin{array}{c}7.189 * * * \\
(0.719)\end{array}$ \\
\hline Fixed effects & CIY & CIY & CIY & CIY & CIY & CIY & CIY & CIY \\
\hline Observations & 15,207 & 15,207 & 18,060 & 18,060 & 10,487 & 10,487 & 23,467 & 23,467 \\
\hline R-squared & $8.5 \%$ & $18.0 \%$ & $7.6 \%$ & $17.4 \%$ & $6.3 \%$ & $14.2 \%$ & $9.3 \%$ & $20.4 \%$ \\
\hline
\end{tabular}




\section{Table IA.3: One-Stage Leverage SOA Regressions}

This table reports the regression results for the effect of the news media on the speed of leverage adjustment (SOA) using the SYSMM estimator for Equation (6'). The dependent variable ( $L E V)$ is measured by either book leverage (BLEV) or market leverage (MLEV). NEWS is a media news variable (NewsCove or NewsTone). NewsCove is the extent of news coverage for a firm in a given year, which is defined as the natural logarithm of one plus the number of news articles that cover news events for the firm in that year. NewsTone is the tone of news for a firm in a given year, which is calculated as the average of the event sentiment score (ESS) for the firm in that year. All models include firm and year fixed effects (FY). The variable definitions are in Appendix A. Standard errors reported in parentheses are clustered. ${ }^{* *}, * *$, and $*$ indicate significance at the $1 \%, 5 \%$, and $10 \%$ levels, respectively.

\begin{tabular}{|c|c|c|}
\hline Variables & $\begin{array}{c}B L e v_{t+1} \\
\text { (1) }\end{array}$ & $\begin{array}{c}M L e v_{t+1} \\
(2)\end{array}$ \\
\hline NewsCove $*$ LEV & $\begin{array}{c}-0.035^{* * *} * \\
(0.008)\end{array}$ & $\begin{array}{c}-0.065^{* * *} * \\
(0.016)\end{array}$ \\
\hline NewsTone*LEV & $\begin{array}{c}-0.137 * * * \\
(0.012)\end{array}$ & $\begin{array}{c}-0.212^{* * * *} \\
(0.017)\end{array}$ \\
\hline$L E V$ & $\begin{array}{c}0.894 * * * \\
(0.036)\end{array}$ & $\begin{array}{c}0.996 * * * \\
(0.070)\end{array}$ \\
\hline$R O A$ & $\begin{array}{c}0.043 * * * \\
(0.008)\end{array}$ & $\begin{array}{c}0.005 \\
(0.009)\end{array}$ \\
\hline$M B$ & $\begin{array}{c}0.001 \\
(0.001)\end{array}$ & $\begin{array}{c}0.009 * * * \\
(0.002)\end{array}$ \\
\hline$D E P$ & $\begin{array}{c}0.011 \\
(0.026)\end{array}$ & $\begin{array}{c}-0.184 * * * \\
(0.030)\end{array}$ \\
\hline SIZE & $\begin{array}{c}0.005^{* * * *} \\
(0.001)\end{array}$ & $\begin{array}{c}0.007 * * * \\
(0.001)\end{array}$ \\
\hline$T A N G$ & $\begin{array}{c}0.004 \\
(0.005)\end{array}$ & $\begin{array}{c}0.044 * * * \\
(0.007)\end{array}$ \\
\hline$R \& D$ & $\begin{array}{c}0.052 * * \\
(0.024)\end{array}$ & $\begin{array}{c}-0.229 * * * \\
(0.048)\end{array}$ \\
\hline$R \& D D$ & $\begin{array}{c}0.008 * * * \\
(0.001)\end{array}$ & $\begin{array}{c}-0.005^{*} \\
(0.003)\end{array}$ \\
\hline$T A X$ & $\begin{array}{c}-0.000 \\
(0.000)\end{array}$ & $\begin{array}{c}-0.000 \\
(0.000)\end{array}$ \\
\hline LIQUID & $\begin{array}{c}-0.047 * * * \\
(0.005)\end{array}$ & $\begin{array}{c}-0.022 * * * \\
(0.007)\end{array}$ \\
\hline INDMed & $\begin{array}{c}0.031 * * * \\
(0.011)\end{array}$ & $\begin{array}{c}-0.495^{* * * *} \\
(0.122)\end{array}$ \\
\hline$I N F L$ & $\begin{array}{c}0.118 * * * \\
(0.034)\end{array}$ & $\begin{array}{c}0.100 * * \\
(0.042)\end{array}$ \\
\hline$G G D P$ & $\begin{array}{l}-0.020 \\
(0.030)\end{array}$ & $\begin{array}{c}0.202^{* * *} \\
(0.059)\end{array}$ \\
\hline Fixed effects & FY & FY \\
\hline Observations & 33,619 & 33,619 \\
\hline Number of firms & 6,778 & 6,778 \\
\hline
\end{tabular}




\section{Table IA.4: National Newspaper Strikes}

This table lists national newspaper strikes that are specific to the publishing and media sectors for the period from 2000 to 2010. The data are from Peress (2014) and Raven Pack.

\begin{tabular}{lll}
\hline \multicolumn{1}{c}{ Country } & \multicolumn{1}{c}{ Year having strikes } & \multicolumn{1}{c}{ Who Strikes } \\
\hline Australia & $2000,2003,2004,2005,2007,2008$ & Journalists/ Print and distribution workers \\
Canada & 2010 & Journalists/ Print and distribution workers \\
France & $2001,2005,2008,2009,2010$ & Print and distribution workers \\
Greece & $2001,2002,2004,2005,2007,2008,2009$, & \\
Italy & 2010 & Journalists \\
Norway & $2000,2002,2003,2005,2006,2010$ & Journalists/ Print and distribution workers \\
United Kingdom & $2001,2002,2004$ & Journalists \\
United States & 2001,2008 & Journalists/ Print and distribution workers \\
\hline & & Journalists/ Print and distribution workers \\
\hline
\end{tabular}




\section{Table IA.5: Instrumental Variable Approach}

This table reports the first-stage and second-stage regression from our IV regressions. In the first stage, we regress the news variables (NewsCove and NewsTone) interacted with DLEV on the instruments and the controls, where a given firm's news coverage and tone are instrumented using its industry-year medians (excluding the firm's news) of news coverage (InDNewsCove) and of news tone (InDNewsTone), respectively. NewsCove is the extent of news coverage for a firm in a given year, which is defined as the natural logarithm of one plus the number of news articles that cover news events for the firm in that year. NewsTone is the tone of news for a firm in a given year, which is calculated as the average of the event sentiment score (ESS) for the firm in that year. In the second stage, we regress the dependent variable $(\triangle L E V)$, the observed change in either book leverage $(\triangle B L E V)$ or market leverage $(\triangle M L E V)$, on the predicted values of NewsCove $\times D L E V$ and NewsTone $\times D L E V$. DLEV is the deviation from target leverage, estimated from Equation (3) using the Blundell and Bond (1998) (two-step) SYSGMM estimator. Country, industry, and year fixed effects (CIY) are included in all models. The variable definitions are in Appendix A. Standard errors are bootstrapped and reported in parentheses. $* * *, * *$, and $*$ indicate significance at the $1 \%, 5 \%$, and $10 \%$ levels, respectively.

\begin{tabular}{|c|c|c|c|c|c|c|c|c|}
\hline \multirow{3}{*}{ Variables } & \multicolumn{4}{|c|}{ News Coverage } & \multicolumn{4}{|c|}{ News Tone } \\
\hline & \multicolumn{2}{|c|}{ Book Leverage } & \multicolumn{2}{|c|}{ Market Leverage } & \multicolumn{2}{|c|}{ Book Leverage } & \multicolumn{2}{|c|}{ Market Leverage } \\
\hline & $\begin{array}{c}\text { 1st stage } \\
\text { NewsCove } \\
\times D L E V \\
(1)\end{array}$ & $\begin{array}{c}\text { 2nd stage } \\
\triangle B L E V_{t+1} \\
\text { (2) }\end{array}$ & $\begin{array}{c}\text { 1st stage } \\
\text { NewsCove } \\
\times D L E V \\
\text { (3) }\end{array}$ & $\begin{array}{c}\text { 2nd stage } \\
\triangle M L E V_{t+1} \\
(4)\end{array}$ & $\begin{array}{c}\text { 1st stage } \\
\text { NewsTone } \\
\times D L E V \\
(5)\end{array}$ & $\begin{array}{c}\text { 2nd stage } \\
\triangle B L E V_{t+1} \\
(6)\end{array}$ & $\begin{array}{c}\text { 1st stage } \\
\text { NewsTone } \\
\times D L E V \\
(7)\end{array}$ & $\begin{array}{c}\text { 2nd stage } \\
\Delta M L E V_{t+1} \\
(8)\end{array}$ \\
\hline NewsCove $\times D L E V$ & & $\begin{array}{c}0.142 * * * \\
(0.008)\end{array}$ & & $\begin{array}{c}0.092 * * * \\
(0.006)\end{array}$ & & & & \\
\hline NewsTone $\times$ DLEV & & & & & & $\begin{array}{c}2.067 * * * \\
(0.207)\end{array}$ & & $\begin{array}{c}2.114 * * * \\
(0.143)\end{array}$ \\
\hline$O V E R \times D L E V$ & $\begin{array}{c}0.172 * * * \\
(0.025)\end{array}$ & $\begin{array}{l}-0.026 \\
(0.035)\end{array}$ & $\begin{array}{c}0.189 * * * \\
(0.028)\end{array}$ & $\begin{array}{c}0.096^{* * *} \\
(0.023)\end{array}$ & $\begin{array}{c}0.007 \\
(0.005)\end{array}$ & $\begin{array}{c}0.183^{* * *} * \\
(0.031)\end{array}$ & $\begin{array}{l}-0.005 \\
(0.006)\end{array}$ & $\begin{array}{c}0.254 * * * \\
(0.023)\end{array}$ \\
\hline$D E F \times D L E V$ & $\begin{array}{c}-0.744 * * * \\
(0.025)\end{array}$ & $\begin{array}{c}0.030 \\
(0.028)\end{array}$ & $\begin{array}{c}-0.726^{* * *} \\
(0.028)\end{array}$ & $\begin{array}{l}-0.000 \\
(0.019)\end{array}$ & $\begin{array}{c}-0.025^{* * *} \\
(0.004)\end{array}$ & $\begin{array}{c}0.175^{* * * *} \\
(0.029)\end{array}$ & $\begin{array}{c}-0.035^{* * *} \\
(0.005)\end{array}$ & $\begin{array}{c}0.118 * * * \\
(0.021)\end{array}$ \\
\hline$D Y \times D L E V$ & $\begin{array}{c}-0.019 * * * \\
(0.004)\end{array}$ & $\begin{array}{c}-0.024 * * * \\
(0.006)\end{array}$ & $\begin{array}{c}-0.016^{* * *} \\
(0.005)\end{array}$ & $\begin{array}{c}-0.003 \\
(0.004)\end{array}$ & $\begin{array}{c}0.004 * * * \\
(0.001)\end{array}$ & $\begin{array}{c}-0.012 * * \\
(0.006)\end{array}$ & $\begin{array}{c}0.008 * * * \\
(0.002)\end{array}$ & $\begin{array}{c}-0.012 * * \\
(0.006)\end{array}$ \\
\hline$G G D P \times D L E V$ & $\begin{array}{c}1.220 * * * \\
(0.436)\end{array}$ & $\begin{array}{c}4.344 * * * \\
(0.615)\end{array}$ & $\begin{array}{l}0.837^{*} \\
(0.445)\end{array}$ & $\begin{array}{c}2.731 * * * \\
(0.388)\end{array}$ & $\begin{array}{l}0.196^{*} \\
(0.110)\end{array}$ & $\begin{array}{c}2.744 * * * \\
(0.749)\end{array}$ & $\begin{array}{l}-0.020 \\
(0.152)\end{array}$ & $\begin{array}{l}-0.363 \\
(0.567)\end{array}$ \\
\hline InDNewsCove $\times D L E V$ & $\begin{array}{c}0.989 * * * \\
(0.007)\end{array}$ & & $\begin{array}{c}0.975 * * * \\
(0.008)\end{array}$ & & & & & \\
\hline InDNewsTone $\times$ DLEV & & & & & $\begin{array}{c}0.959 * * * \\
(0.030)\end{array}$ & & $\begin{array}{c}0.980 * * * \\
(0.036)\end{array}$ & \\
\hline Fixed effects & CIY & CIY & CIY & CIY & CIY & CIY & CIY & CIY \\
\hline Observations & 33,267 & 33,267 & 33,267 & 33,267 & 33,267 & 33,267 & 33,267 & 33,267 \\
\hline R-squared & $92.4 \%$ & $7.3 \%$ & $91.5 \%$ & $16.6 \%$ & $32.3 \%$ & $4.9 \%$ & $27.8 \%$ & $11.2 \%$ \\
\hline
\end{tabular}




\section{Table IA.6: Media News Coverage and Leverage Adjustment Activities: Univariate Analysis}

The table presents the frequency and magnitude of external leverage adjustment patterns for firms with high and low media coverage (Panel A) as well as those with a positive and negative media tone (Panel B). Firm with high (low) media coverage are those with above-median news coverage in a given year. A debt issuance (D.Issue), debt retirement (D.Retire), or equity issuance (E.Equity) is defined as a security issuance or repurchase of at least $5 \%$ of the book assets. An equity retirement (E.Retire) is defined as a stock repurchase of at least $1.25 \%$ of the book assets. $T$-stat is the $t$-statistics of the difference in group means.

\begin{tabular}{|c|c|c|c|c|}
\hline \multicolumn{5}{|l|}{ Panel A: Media coverage } \\
\hline \multicolumn{5}{|c|}{ I: Incidence of capital market access } \\
\hline \multicolumn{5}{|c|}{ Frequency of adjustments } \\
\hline & D.Isssue & D.Retire & E.Issue & E.Retire \\
\hline High media coverage & 0.473 & 0.300 & 0.432 & 0.130 \\
\hline Low media coverage & 0.432 & 0.284 & 0.406 & 0.114 \\
\hline Difference [High-Low] & 0.041 & 0.016 & 0.026 & 0.016 \\
\hline$t$-stat & 5.600 & 2.277 & 4.836 & 4.526 \\
\hline \multicolumn{5}{|c|}{ II: Mean size of capital market transaction } \\
\hline \multicolumn{5}{|c|}{ Size of adjustments } \\
\hline & D.Isssue & D.Retire & E.Issue & E.Retire \\
\hline High media coverage & 0.049 & -0.0151 & 0.053 & -0.020 \\
\hline Low media coverage & 0.041 & -0.0150 & 0.049 & -0.017 \\
\hline Difference [High-Low] & 0.008 & -0.0001 & 0.004 & -0.003 \\
\hline t-stat & 6.192 & -0.1764 & 4.386 & -4.870 \\
\hline \multicolumn{5}{|l|}{ Panel B: Media tone } \\
\hline \multicolumn{5}{|c|}{ I: Incidence of capital market access } \\
\hline \multicolumn{5}{|c|}{ Frequency of adjustments } \\
\hline & D.Isssue & D.Retire & E.Issue & E.Retire \\
\hline Positive tone & 0.464 & 0.296 & 0.467 & 0.092 \\
\hline Negative tone & 0.421 & 0.277 & 0.280 & 0.210 \\
\hline Difference [Positive-Negative] & 0.043 & 0.020 & 0.187 & -0.118 \\
\hline$t$-stat & 5.133 & 2.423 & 30.649 & -29.114 \\
\hline \multicolumn{5}{|c|}{ II: Mean size of capital market transaction } \\
\hline \multicolumn{5}{|c|}{ Size of adjustments } \\
\hline & D.Isssue & D.Retire & E.Issue & E.Retire \\
\hline Positive tone & 0.047 & -0.015 & 0.057 & -0.013 \\
\hline Negative tone & 0.037 & -0.014 & 0.031 & -0.032 \\
\hline Difference [Positive-Negative] & 0.011 & -0.001 & 0.026 & 0.019 \\
\hline t-stat & 7.582 & -2.656 & 25.968 & 24.604 \\
\hline
\end{tabular}




\section{Table IA.7: News Media Coverage and Cost of Capital}

This table provides the regression results for the effects of the news media on the cost of capital (ICOC), which is measured as the average of the four estimates for the implied cost of equity capital as described in the text. NewsCove is the extent of news coverage for a firm in a given year, which is defined as the natural logarithm of one plus the number of news articles that cover news events for the firm in that year. NewsTone is the tone of news for a firm in a given year, which is calculated as the average of the event sentiment score (ESS) for the firm in that year. BETA is market beta, which is measured relative to the world market index and estimated based on a five-year market model regression; ANAERROR is analyst forecast error, which is computed as the difference between actual earnings per share (EPS) and consensus mean forecasted EPS scaled by stock price; $M B$ is market-to-book ratio; STD is return volatility; SIZE is firm size. Country, industry, and year fixed effects (CIY) are included in all models. Standard errors reported in parentheses are adjusted for heteroscedasticity and firm-level clustering. The variable definitions are in Appendix A. *, **, and $* * *$ indicate significance at the $10 \%, 5 \%$, and $1 \%$ levels.

\begin{tabular}{lccc}
\hline Variables & ICOC & ICOC & ICOC \\
& $(1)$ & $(2)$ & $(3)$ \\
\hline NewsCove & $-0.001^{* * * *}$ & & $-0.001^{* * *}$ \\
& $(0.000)$ & $-0.005^{* * *}$ & $(0.000)$ \\
NewsTone & & $(0.001)$ & $-0.006^{* * *}$ \\
BETA & & 0.001 & $(0.001)$ \\
& 0.001 & $(0.000)$ & 0.001 \\
ANAERROR & $(0.000)$ & $0.005^{* * *}$ & $(0.000)$ \\
& $0.005^{* * *}$ & $(0.000)$ & $0.005^{* * *}$ \\
MB & $(0.000)$ & $-0.012^{* * *}$ & $(0.000)$ \\
& $-0.012^{* * *}$ & $(0.000)$ & $-0.012^{* * *}$ \\
STD & $(0.000)$ & $0.040^{* * * *}$ & $(0.000)$ \\
& $0.040^{* * *}$ & $(0.002)$ & $0.040^{* * *}$ \\
SIZE & $(0.002)$ & $-0.003^{* * *}$ & $(0.002)$ \\
& $-0.003^{* * *}$ & $(0.000)$ & $-0.003 * * *$ \\
Fixed effects & $(0.000)$ & $\mathrm{CIY}$ & $(0.000)$ \\
Observations & $\mathrm{CIY}$ & 28,020 & $\mathrm{CIY}$ \\
R-squared & 28,020 & $45.1 \%$ & 28,020 \\
\hline
\end{tabular}




\section{Table IA.8: Nonlinear Effects of the News Media on the Speed of Leverage Adjustment}

This table reports the regression results for the nonlinear effect of the news media on the speed of leverage adjustment (SOA). We estimate an augmented model of Equation (6), where the dependent variable $(\triangle L E V)$ is the observed change in either book leverage $(\triangle B L E V)$ or market leverage $(\triangle M L E V)$. NewsCove is the extent of news coverage for a firm in a given year, which is defined as the natural logarithm of one plus the number of news articles that cover news events for the firm in that year. NewsTone is the tone of news for a firm in a given year, which is calculated as the average of the event sentiment score $(E S S)$ for the firm in that year. $D L E V$ is the deviation from target leverage, estimated from Equation (3) using the Blundell and Bond (1998) (two-step) SYSGMM estimator. OVER is a dummy that equals one if the firm is over-levered relative to target leverage (Models (1) and (2)). HIGHCOV is a dummy variable that equals one if the firm has news coverage in excess of the median value of all sample firms in each country in a given year (Models (3) and (4)). POSITIVE is a dummy variable that equals one if the news tone for the firm is positive (Models (5) and (6)), and zero otherwise. Country, industry, and year fixed effects (CIY) are included in all models. The variable definitions are in Appendix A. Standard errors are bootstrapped and reported in parentheses. ***, **, and * indicate significance at the $1 \%, 5 \%$, and $10 \%$ levels, respectively.

\begin{tabular}{|c|c|c|c|c|c|c|}
\hline \multirow[b]{2}{*}{ Variables } & \multicolumn{2}{|c|}{ Over-Levered Firm } & \multicolumn{2}{|c|}{ High Media Coverage } & \multicolumn{2}{|c|}{ Positive Media Tone } \\
\hline & $\begin{array}{c}\triangle B L E V_{t+1} \\
\text { (1) }\end{array}$ & $\begin{array}{c}\Delta M L E V_{t+1} \\
\text { (2) }\end{array}$ & $\begin{array}{c}\Delta B L E V_{t+1} \\
\text { (3) }\end{array}$ & $\begin{array}{c}\Delta M L E V_{t+1} \\
(4)\end{array}$ & $\begin{array}{c}\triangle B L E V_{t+1} \\
(5)\end{array}$ & $\begin{array}{c}\Delta M L E V_{t+1} \\
(6)\end{array}$ \\
\hline NewsCove $\times D L E V$ & $\begin{array}{c}0.127 * * * \\
(0.008)\end{array}$ & $\begin{array}{c}0.066^{* * *} \\
(0.006)\end{array}$ & $\begin{array}{c}0.118 * * * \\
(0.017)\end{array}$ & $\begin{array}{c}0.057 * * * \\
(0.011)\end{array}$ & $\begin{array}{c}0.072 * * * \\
(0.016)\end{array}$ & $\begin{array}{c}0.029 * * * \\
(0.008)\end{array}$ \\
\hline NewsTone $\times D L E V$ & $\begin{array}{c}0.365^{* * * *} \\
(0.066)\end{array}$ & $\begin{array}{c}0.359 * * * \\
(0.067)\end{array}$ & $\begin{array}{c}0.512 * * * \\
(0.075)\end{array}$ & $\begin{array}{c}0.481 * * * \\
(0.043)\end{array}$ & $\begin{array}{l}0.280 * \\
(0.150)\end{array}$ & $\begin{array}{c}0.299 * * * \\
(0.107)\end{array}$ \\
\hline NewsCove $\times D L E V \times O V E R$ & $\begin{array}{c}-0.124 * * * \\
(0.016)\end{array}$ & $\begin{array}{l}-0.024 \\
(0.015)\end{array}$ & & & & \\
\hline NewsTone $\times D L E V \times O V E R$ & $\begin{array}{c}0.536 * * * \\
(0.153)\end{array}$ & $\begin{array}{c}0.385^{* * *} \\
(0.089)\end{array}$ & & & & \\
\hline NewsCove $\times D L E V \times H I G H C O V$ & & & $\begin{array}{c}-0.026^{*} \\
(0.014)\end{array}$ & $\begin{array}{c}-0.009 \\
(0.011)\end{array}$ & & \\
\hline NewsTone $\times D L E V \times H I G H C O V$ & & & $\begin{array}{c}0.452 * * * \\
(0.122)\end{array}$ & $\begin{array}{c}0.424 * * * \\
(0.098)\end{array}$ & & \\
\hline NewsCove $\times D L E V \times P O S I T I V E$ & & & & & $\begin{array}{c}0.034 * * \\
(0.015)\end{array}$ & $\begin{array}{c}0.035^{* * *} \\
(0.009)\end{array}$ \\
\hline NewsTone $\times D L E V \times P O S I T I V E$ & & & & & $\begin{array}{l}0.344 * \\
(0.178)\end{array}$ & $\begin{array}{l}0.244 * \\
(0.125)\end{array}$ \\
\hline Controls $\times D L E V$ & Yes & Yes & Yes & Yes & Yes & Yes \\
\hline Fixed effects & CIY & CIY & CIY & CIY & CIY & CIY \\
\hline Observations & 33,267 & 33,267 & 33,267 & 33,267 & 33,267 & 33,267 \\
\hline R-squared & $8.0 \%$ & $17.6 \%$ & $7.8 \%$ & $17.6 \%$ & $7.8 \%$ & $17.6 \%$ \\
\hline
\end{tabular}

